PAULA MARIA ELBL

ESTUDOS EM COMMELINACEAE (MONOCOTILEDÔNEAS): O

PAPEL DA ENDODERME E DO PERICICLO NA FORMAÇÃO DO CORPO PRIMÁRIO.

São Paulo

2008 
PAULA MARIA ELBL

\section{ESTUDOS EM COMMELINACEAE (MONOCOTILEDÔNEAS): O PAPEL DA ENDODERME E DO PERICICLO NA FORMAÇÃO DO CORPO PRIMÁRIO.}

Dissertação apresentada ao Instituto de Biociências da Universidade de São Paulo para a obtenção de Título de Mestre em Ciências, na Área de Botânica.

Orientador(a): Nanuza Luiza de Menezes

São Paulo 2008 
Elbl, Paula Maria

Estudos em Commelinaceae (Monocotiledôneas): o papel da endoderme e do periciclo na formação do corpo primário.

167 páginas

Dissertação (Mestrado) - Instituto de Biociências da Universidade de São Paulo. Departamento de Botânica.

1. Commelinaceae 2. Endoderme 3. Periciclo Universidade de São Paulo. Instituto de Biociências. Departamento de Botânica.

\section{Comissão Julgadora:}

$\operatorname{Prof}(\mathrm{a}) . \operatorname{Dr}(\mathrm{a})$.

$\operatorname{Prof(a).} \operatorname{Dr}(\mathrm{a})$.

Prof $^{a}$. Titular Nanuza Luiza de Menezes

Orientadora 
Aos meus pais pelo eterno amor e incentivo,

Ao Evaldo, cujo apoio, carinho, amor, dedicação e companheirismo foram indispensáveis. 


\section{AGRADECIMENTOS}

À minha querida orientadora, Professora Titular, Nanuza Luiza de Menezes, por sua presteza, carinho e valorosa orientação. Estar ao seu lado é um privilégio e uma fonte de inspiração para minha vida pessoal e acadêmica.

À Professora Dalva Cassie Rocha por ter me apresentado o belo mundo da anatomia vegetal.

À Professora Gladys Flávia de Albuquerque Melo-de-Pinna, pelos conselhos, incentivos e dicas muito proveitosas.

Ao Professor Gregório Cardoso Tapias Ceccantini pelo grande estímulo, desde a minha chegada.

À Professora Verônica Angyalossy pelos conselhos e incentivos.

Ao Professor Titular José Deodoro Trani Capocchi pelos constantes incentivos, conselhos e amizade.

Ao Professor Osvaldo Mitsuyuki Cintho pela grande ajuda no ínicio de minha vida em São Paulo e em diversos outros momentos durante a preparação deste trabalho.

Ao Conselho Nacional de Desenvolvimento Científico e Tecnológico (CNPq) e à Fundação de Amparo à Pesquisa do Estado de São Paulo pela bolsa de Mestrado concedida.

Ao Departamento de Botânica do Instituto de Biociências da USP, seus funcionários e docentes, pelos serviços prestados no Laboratório de Anatomia Vegetal (LAV) e demais dependências.

Ao Noberto Palácios pelo grande apoio em diversas questões burocráticas. 
À Gisele Costa, técnica do Laboratório de Anatomia Vegetal, pela amizade, pela grande colaboração e atenção dispensada em diversos procedimentos e análises.

Aos amigos e colegas que souberam compreender e dar apoio, de formas variadas, para a concretização e conclusão deste trabalho: Celina Nakamura, Bianca Brasil, Gustavo Burin, Guilherme de Queiroz Freire, José Hernandes Lopes Filho, Marli Botânico, Marcelo Pace, Marina Cattai, Marina Milanello, Vera Alves, e Renata C. Cassimiro de Lemos. Em especial, às amigas e amigos Cristiane Gonçalves da Silva, Deusa Deise de Abreu, Emília C. Arruda, Thais Montureano, Viviane Yuri Jono, Giuliano Locosseli, Mariane Souza, Vanessa Godofredo, Natália Antonucci.

Às minhas avós Amália Mazza da Fonseca (Naná) e llda Elbl, aos meus pais Balthazar Elbl Neto e Rosangela do Carmo Elbl; aos meus irmãos João Maurício, Elisangela e Mariangela; aos meus lindos sobrinhos Ana Flávia, Guilherme, Gustavo, Otávio, André Luís e a mais nova da turma Giovana; aos meus sogros Agostinho e Ivone Kubaski; às minhas cunhadas Ândrea e Ana Claudia pela presença em todos os momentos, pelo estímulo e carinho.

Meus sinceros agradecimentos! 


\section{LISTA DE FIGURAS}

Fig. 1.1A-F - Seções transversais da raiz de Commelina erecta. As Fig 1.1A e $\mathrm{D}$ mostram a região próxima ao ápice envolvida pela coifa (Cf) com o córtex (Ct) radiado, as derivadas da endoderme meristemática (DEM) e as iniciais endodérmicas (le). Fig. 1.1B-C e E-F: região onde os tecidos primários estão completamente diferenciados, notando-se ainda uma epiderme (Ep) unisseriada e a hipoderme ( $\mathrm{Hp}$ ) unisseriada; abaixo dela 3 a 4 camadas de células corticais com paredes espessadas e o restante do córtex $(\mathrm{Ct}) \mathrm{com}$ paredes primárias e a radiação de células bem marcadas, especialmente nas primeiras camadas do córtex interno. Ce- Córtex externo; En- Endoderme; FIFloema; Mx- Metaxilema; Pr- Periciclo; Px- Protoxilema 67

Fig. 1.2A-H - Seções transversais da raiz de Dichorisandra tyrsiflora notando-se nas Fig. 1.2B e $\mathrm{H}$ em destaque, células da hipoderme $(\mathrm{Hp})$ e da endoderme (En) e na Fig. 1.2H pela reação hemisulfato de Berberina exposta à fluorescência. Ct- Córtex; Ep- Epiderme; Fl- Floema; Mx- Metaxilema; PrPericiclo; Px- Protoxilema.

Fig. 1.3A-D - Seções longitudinais de raiz de Dichorisandra tyrsiflora destacando-se o centro quiescente $(\mathrm{Cq})$ nas Fig. 1.3B e C. Cf- Coifa; Pa- Pêlo absorvente; Pt- Protoderme.

Fig. 1.4A-F - Seções longitudinal (Fig. 1.4A) e transversais (Fig. 1.4B-F) da raiz de Floscopa glabrata. Fig.1.4A seção longitudinal do ápice no qual se verificam a protoderme $(\mathrm{Pt})$, a região correspondente a derivadas da endoderme meristemática (DEM) da Fig.1.4C, o procâmbio (Pc) e a coifa (Cf). Fig. 1.4B: aspecto geral de uma seção transversal região da raiz envolvida pela coifa. Fig. 1.4C: ampliação da Fig. 1.4A: notando-se o córtex radiado com inicial endodérmica (le) e as derivadas da endoderme meristemática (DEM), observando-se espaços entre as células mais distantes das iniciais endodérmicas. Fig. 1.4D, 1.4D', 1.4E e 1.4F: regiões com tecidos primários diferenciados, observando-se no detalhe da Fig. 1.4D' a célula inicial endodérmica não dividida (cabeça de seta) entre células iniciais recémdivididas. Fig. 1.4F, observa-se no córtex um aerênquima (Ae). EnEndoderme; Ep- Epiderme; Fl- Floema; Hp- hipoderme Me- medula; MxMetaxilema; Pr- Periciclo; Px- Protoxilema. 70

Fig. 1.5A-D - Seções longitudinais da raiz de Floscopa glabrata destacando o centro de quiecência (Fig. 1.5A), a protoderme (Pt), o meristema fundamental (Mf) nas Fig. 1.5B e D e a inicial endodérmica (le) na Fig. 1.5D. Cf- Coifa; PcProcâmbio. 71

Fig. 1.6A-G - Seções transversais (1.6A-D) da raiz de Tradescantia spathacea. Fig 1.6A, onde se observam as DEM (Derivadas da endoderme meristemática). Observa-se o córtex $(\mathrm{Ct})$ radiado constituído pelas derivadas da endoderme meristemática (Fig. 1.6A-C), a endoderme (En) com reforço em $U$, os tecidos vasculares diferenciados (Fig. 1.6B) e o metaxilema $(\mathrm{Mx})$ em diferenciação (Fig 
1.6B, cabeça de seta). Fig. 1.6D, observa-se uma célula endodérmica não dividida (seta preta) ao lado de células que sofreram mais uma divisão (seta branca). A cabeça de seta da Fig. 1.6D indica célula pericíclica em divisão. MeMedula; Pr- Periciclo; Px- Protoxilema. 72

Fig. 1.7A-G - Seções longitudinais (1.7A-D) e transversais (1.7E-G) da raiz de Tradescantia spathacea nas quais se observam as células da protoderme $(\mathrm{Pt})$ e as suas resultantes $(R p)$ originando o velame (Ve)(Fig. 1.7 A-D), observado nas Fig. 1.7E-G. As setas indicam as fileiras resultantes da mesma célula protodérmica. A textura das células do epivelame (Ev) apresentam as paredes das células com a mesma textura Fig. 1.7E-G........................................... 73

Fig. 1.8A-G - Seções longitudinal (Fig. 1.8A) e transversais (Fig. 1.8B-G) da raiz de Tradescantia zebrina. Fig 1.8A-D: tecidos imaturos e Fig. 1.8E-G com tecidos diferenciados; chama-se atenção para o córtex externo (Ce) que nesta raiz apresenta-se com as paredes espessadas e também para as células da endoderme (En) que sofreram uma divisão a mais (Fig. 3G seta preta) do que a indicada pela seta branca. Cf- Coifa; Ct- Córtex; Cv- Cilindro vascular; DEMDerivadas da Endoderme Meristemática; Ep- Epiderme; le - Inicial endodérmica; Hp- Hipoderme; Pr- Periciclo. 74

Fig. 1.9A-D - Seções longitudinais da raiz de Tradescantia zebrina notando-se o centro quiescente em destaque na Fig. 1.9B e na Fig. 1.9D, célula do meristema fundamental (Mf) que originou a inicial endodérmica (le) e outra do meristema (seta). Cf- Coifa; Pc- Procâmbio................................................. 75

Fig. 1.10 - Esquema representando a fase de divisão da endoderme. Em 1, (região próxima ao ápice da raiz) a célula $(\mathbf{A} / \mathbf{B})$ pró-endoderme está se dividindo, notando-se o periciclo (Pr) e a epiderme (Ep). Em 2, a divisão da pró-endoderme deu origem a duas células filhas: a célula $(\mathbf{A})$, que representa a célula filha que permanecerá em divisão; a célula (B), célula filha que se torna madura (derivada), formando o córtex da raiz. Em 3 o córtex já está formado e a endoderme perde a capacidade de divisão iniciando o processo de diferenciação. Em 4 a endoderme apresenta-se com estrias de Caspary. ..... 76

Fig. 2.1 - Representação esquemática das espécies analisadas mostrando a diversidade de hábitos. A linha horizontal preta representa o solo. A linha horizontal azul a água, pois Floscopa glabrata é uma espécie anfíbia. ......... 106

Fig. 2.2A-E - Aspecto geral das espécies (Fig. 2.2A) Commelina erecta, (Fig. 2.2B) Floscopa glabrata, (Fig. 2.2C) Dichorisandra tyrsiflora, (Fig. 2.2D) Tradescantia spathacea, (Fig. 2.2E) Tradescantia zebrina............................ 107

Fig. 2.3 - Representação esquemática do desenvolvimento do eixo caulinar subterrâneo de Tradescantia spathacea (do primeiro ao quinto mês de desenvolvimento). No esquema (Fig. 2.3A) nota-se o desenvolvimento do eixo caulinar a partir da base do nó cotiledonar, abaixo (Fig. 2.3B), em detalhe, a seta indica o eixo caulinar subterrâneo. Fig. 2.3C: o indivíduo adulto onde notase a porção aérea e a subterrânea $(\mathrm{Sb})$. 108 
Fig. 2.4A-G - Seções transversais da região do entrenó do caule de Floscopa glabrata (Fig. 2.4A-G) observando-se um córtex (Ct) pouco espesso em relação ao cilindro vascular; verifica-se uma concentração maior de feixes vasculares na região perimedular perfeitamente envolvido por uma endoderme (Fig. 2.4C$E$, En). Esses feixes são formados na região pericíclica $(\mathrm{Pr})$. Os feixes medulares são constituídos por poucos elementos vasculares (Fig. 2.4F) e nas regiões cortical e medular (Me) observam-se espaços aéreos. (Fig. 2.4B, E-G, Ae). Ep- Epiderme; Fc- Feixe caulinar; St- estômato, Tf- Traço foliar............. 109

Fig. 2.5A-D - Seções transversais de caule de Floscopa glabrata notando-se dois traços foliares (2.5A e B) e a posição periférica dos feixes caulinares formados pelo periciclo ( $\mathrm{Pr}$ ) envolvidos pela endoderme (En). Nas Fig. 2.5B e $\mathrm{D}$, tratadas com hemisulfato de berberina, sob fluorescência, o traço foliar com calota de fibras, (Fig. 2.5D) sob fluorescência, notando-se a endoderme, bem distinta pela cor laranja e o periciclo na cor branca...................................... 110

Fig. 2.6A-D - Seções transversais da região do nó de Floscopa glabrata, onde se percebe a região pericíclica $(\operatorname{Pr})$ mais espessada e uma região formada por células em atividade ( $\mathrm{Ca})$. Na Fig. $6 \mathrm{~A}$ a estria de Caspary está realçada por hemisulfato de berberina e na Fig. 6B, com safranina. Endoderme (En). CsCélulas espessadas. 111

Fig. 2.7A-C. Ápice vegetativo de Floscopa glabrata notando-se células do procâmbio $(\mathrm{Pc})$ e do meristema fundamental $(\mathrm{Mf})$ e na seqüência, o periciclo $(\operatorname{Pr})$ e a endoderme (En). Mi- meristema intercalar.As setas indicam o limite entre o córtex e o cilindro central. 112

Fig. 2.8A-D - Seções transversais de Floscopa glabrata mostrando a região do nó onde se observa a saída de traços foliares (Tf) envolvidos pela endoderme (En) destacada por hemisulfato de berberina. Fig. 2.8C-D saída de raiz adventícia (Ra) sendo que na Fig. $2.8 \mathrm{C}$ observa-se a presença do plexo $(\mathrm{PI})$ em direção à nova raiz, e a endoderme ressaltada na Fig. 2.8D por hemisulfato de berberina. DEM- derivadas da endoderme meristemática. 113

Fig. 2.9A-G. Seções transversais do sistema subterrâneo caulinar de Floscopa glabrata, notando-se o plexo periférico (PI) na região pericíclica (Fig. 2.9A e B), a presença de dois cilindros em 2.9B, feixes no interior da região medular (Me) (Fig. 2.9C), saída de raiz adventícia (Ra) e respectivo plexo (Fig. 2.9D) e região pericíclica ( $\mathrm{Pr}$ ) com plexo (Fig. 2.9E). Saída do traço foliar (Tf) (Fig. 2.9F) e aspecto geral dos feixes pericíclicos $(\mathrm{Fp})$ envolvidos externamente pela endoderme (En). A Fig. 2.9F mostra feixes periciclícos ( $F p)$ e, internamente, fusão de tecidos vasculares formando um cilindro. Na Fig. 2.9G destaca-se, com auxilio do hemisulafto de berberina, os conjuntos de feixes pericíclicos $(\mathrm{Fp})$, formando o cilindro vascular. Fc- Feixe caulinar................................... 114

Fig. 2.10A-E - Seções transversais (Fig. 2.10A) e longitudinais (Fig. 2.10B-E) de Floscopa glabrata notando-se saída de raiz adventícia (Ra), com a medula (Me) totalmente lignificada, destacando-se a endoderme (En). A Fig. $2.10 \mathrm{~B}$ evidencia bem a natureza simpodial do sistema caulinar. Na Fig. 2.10D e E nota-se na endoderme com espessamento. Li - Limite do cilindro central; PIPlexo radicular....................................................................................... 115 
Fig. 2.11A- F - Seções longitudinais do ápice vegetativo de Tradescantia zebrina (Fig. 2.11A-D) e transversais (Fig. 2.11E-F) do caule na região do nó. Os cordões de procâmbio $(\mathrm{Pc})$ podem ser observados na Fig. 2.11A, na região central do entrenó e a Fig. 2.11C é um destaque demarcado na figura 2.11A, onde se observam a inicial endodérmica (le) e a região pericíclica (Pr). Esta mesma região aparece também na Fig. 2.11D notando-se em ambas, provavelmente uma inicial endodérmica (le). Nas Fig. 2.11E-F, nota-se uma gema axilar (Ga) com o procâmbio em conexão com o periciclo que está formando um feixe novo (Fig. 2.11F, Fn). En- Endoderme, Pm- Pró-meristema.

Fig. 2.12A-F.- Seções transversais do entrenó de caule de Tradescantia zebrina (Fig. 2.12A-C) e seção longitudinal (Fig. 2.12D-F). Nota-se o córtex (Ct) estreito e, em detalhe, a endoderme (En) e o periciclo ( $\mathrm{Pr}$ ) unisseriado. Observam-se as lacunas do protoxilema $(\mathrm{Px})$ de dois traços foliares na região da medula (Me) Fig. 2.12C. A endoderme em seções longitudinais (Fig 2.12E e F). Na Fig. 2.12E mostra, em seção longitudinal, o traço foliar (Tf) localizado na região medular; pode-se observar o elemento de protoxilema (Px). Na Fig $2.12 \mathrm{~F} \circ$ feixe da região perimedular de origem pericíclica (Fp) longitudinalmente. Ep- Epiderme; Hp- hipoderme..................................... 117

Fig. 2.13A-H - Seções longitudinal (Fig. 2.13A) e transversais (Fig. 2.13B-H) de Tradescantia zebrina, na região do nó. Fig. 2.13A: região do nó onde se observa uma configuração dos feixes vasculares, com certo entrelaçamento entre os feixes de dois nós consecutivos. Fig. 2.13B-F observam-se saídas de raízes adventícias $(\mathrm{Ra})$ e traços foliares $(\mathrm{Tf})$ perpendiculares à superfície do órgão; é perfeitamente clara a formação das raízes adventícias no periciclo (Pr), melhor observado na Fig. 2.13F; e também o plexo $(\mathrm{PI})$ em direção à raiz na Fig. 2.13G. Na Fig. 2.13H, observam-se complexos vasculares (Cx), que correspondem ao indicado por seta na Fig. 2.13A, da região do nó. Ct- Córtex; DEM- derivadas da endoderme meristemática; Ga- Gema axilar; Cv cilindro vascular. 118

Fig. 2.14A-D - Seções transversais da região do entrenó do caule de Commelina erecta, onde se percebe a endoderme (En) parenquimática como a camada mais interna do córtex (Ct). Observam-se os feixes vasculares caulinares $(\mathrm{Fc})$ na região pericíclica $(\mathrm{Pr})$ perfeitamente envolvidos por uma endoderme, sendo possível observar as células do periciclo espessadas e a endoderme, que em alguns pontos, mostra células em divisão (Fig. 2.14C). Na Fig. 2.14D observam-se traços foliares (Tf) dispostos na medula (Me). EpEpiderme. 119

Fig. 2.15A-D - Seções transversais da região do segundo nó do caule de Commelina erecta. Fig. 15A-B: notam-se traços foliares (Tf) providos de uma calota de fibras na região da medula (Me). Fig. 2.15C-D: observam-se, além dos feixes caulinares $(\mathrm{Fc})$ periféricos, a presença de plexos $(\mathrm{Pl})$ na região interna. O sistema vascular, na região pericíclica $(\mathrm{Pr})$ aparece separando em porções envolvidas por fibras pericíclicas. 120

Fig. 2.16A-D - Seções transversais em Commelina erecta da mesma região representada nas Fig 2.16A-D Observam-se os feixes caulinares (Fc) 
periféricos em grupos menores (Fig. 2.16A) ou maiores (Fig. 2.16C) envolvidos por fibras pericíclicas. Fig. 2.16B a endoderme (En) com estrias de Caspary e 0 plexo $(\mathrm{Pl})$ na região pericíclica $(\mathrm{Pr})$. Fig. 2.16C: saída de traço foliar (Tf) e presença de fusão de feixes internamente ao periciclo (Fig. 2.16D). Ct- Córtex; Ga- Gema axilar; PI-Plexo. 121

Fig. 2.17A-F -. Seções longitudinais (Fig. 2.17A, C e E) e transversais (Fig. 2.17A, B, D e F) de Commelina erecta. Fig 2.17A-C: observa-se a saída de um ramo na região do nó, que na Fig. 2.17E mostra três raízes adventícias $(\mathrm{Ra})$ em seção transversal. Fig 2.17B região pericíclica $(\mathrm{Pr})$ do caule com endoderme (En) e região pericíclica. Fig. 2.17D traço foliar (Tf) e Fig 2.17F

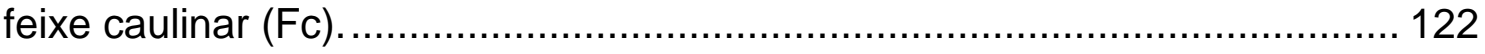

Fig. 2.18A-D. - Seções longitudinal do ápice (Fig. 2.18A) e transversais do caule aéreo próximo ao ápice (Fig. 2.18B-D) de Tradescantia spathacea . Na Fig 2.18A é possível observar, no destaque, o periciclo, e exatamente as resultantes da endoderme com atividade meristemática. Próximo ao ápice se distingui a endoderme (En) por ser a camada mais interna do córtex (Fig. 2.18B-C). Notam-se nas Fig. 2.18C-D feixes caulinares (Fc) e traços foliares (Tf). 123

Fig. 2.19A-F - Seções transversais do caule de Tradescantia spathacea com tecidos mais diferenciados, notando-se a endoderme (En) (Fig. 2.19A-C) inclusive mostrando divisões (Fig. 2.19C), a região pericíclica ( $\mathrm{Pr}$ ) em grande atividade (Fig. 2.19A-C) e o súber estratificado (S) na Fig 2.19A e D. Nas Fig 2.19E-F observa-se no detalhe a saída de raiz adventícia $(\mathrm{Ra})$ e a presença das derivadas da endoderme (DEM). Ctc: Córtex caulinar, Ctr; Córtex da raiz adventícia; Me- Medula. 124

Fig. 2.20A-H. - Seções transversais do caule de Dichorisandra tyrsiflora em regiões mais próximas do ápice (Fig. 2.20A-D), nas quais, o limite do sistema vascular torna-se visível com o aparecimento do plexo periférico (PI) (Fig 2.20E-H) na região pericíclica ( $\mathrm{Pr}$ ) para a formação de uma raiz adventícia $(\mathrm{Ra})$. A endoderme $(\mathrm{En})$ reconhecida por ser a camada mais interna do córtex (Fig 2.20A-B), nas Fig. 2.20H ainda aparece em divisão, podendo se distinguir a Inicial endodérmica (le). Me- Medula. 125

Fig. 2.21A-G - Seções transversais do caule Dichorisandra tyrsiflora notando-se além do plexo periférico $(\mathrm{PI})$ na região pericíclica, as derivadas da endoderme meristemática (Fig. 2.21A e B). Na Fig. 2.21C e D distingui-se bem a endoderme $(E n)$, a região pericíclica $(\mathrm{Pr})$ e o plexo periférico $(\mathrm{PI})$ na região pericíclica. Observam-se os traços foliares (Tf) atravessando a região cortical (Fig. 2.21E), em detalhe, o traço foliar com protoxilema (Px) e na Fig. 2.21G o traço foliar alcançando a bainha da folha tornando-se um feixe da folha (Fx). 126

Fig. 2.22A-G. Seções transversais do rizoma de Dichorisandra tyrsiflora notando-se a o córtex (Ct) e o cilindro vascular (Cv) (Fig. 2.22A-B). Pode-se observar o plexo periférico $(\mathrm{PI})$, a região pericíclica $(\mathrm{Pr})$ e a endoderme com estrias de Caspary (Fig. 2.22C-E). Na Fig. 2.22E a estria é evidenciada por hemisulfato de berberina. 127 
Fig. 2.23 - Testes microquímicos para visualização da endoderme, realizados para o entrenó de Commelina erecta, Floscopa glabrata e Tradescantia zebrina. Barra $=250 \mu \mathrm{m}$. 128

Fig. 3.1A-D - Seções tranversais dos caules (região nodal) de Tradescantia zebrina (Fig. 3.1A-C), Commelina erecta Fig. 3.1B) e Floscopa glabrata (Fig 3.1D), sendo esta sob fluorescência. Nota-se a continuidade dos tecidos entre o caule e a folha, na Fig 3.1A -C nota-se os complexos vasculares (Cx) e os traços foliares indo em direção à bainha da folha $(\mathrm{Ba})$. Fig 3.1D: pode- se observar a endoderme (En) envolvendo o traço foliar. Uv- Unidade vascular.

Fig. 3.2A-J - Seções transversais da folhas de Commelina erecta (Fig. 3.2A-B), Dichorisandra tyrsiflora (Fig. 3.2C-D), Floscopa glabrata (Fig. 3.2E-F), Tradescantia spathacea (Fig. 3.2G-H) e Tradescantia zebrina(Fig. 3.2I-J). EnEndoderme. 148

Fig. 3.3A-J - Aspecto anatômico geral da folhas de Commelina erecta (Fig. 3.3A-D), Floscopa glabrata (Fig. 3.3E-H), notando-se as unidades vasculares envolvidas pela endoderme (En) e periciclo ( $\mathrm{Pr})$. 149

Fig. 3.4A-F - Seções transversais das folhas de Tradescantia spathacea(Fig. 3.4A-B); Tradescantia zebrina (Fig. 3.4C) e Dichorisandra tyrsiflora (Fig. 3.4DF) notando-se as unidades vaculares envolvidas pela endoderme (En) e periciclo $(\mathrm{Pr})$. 150

Fig. 4.1A-D - Vista frontal da folha minada de Commelina diffusa e Floscopa glabrata. (Commelinaceae) a partir de material diafanizado. Fig. 4.1A-B: larva de Agromyzidae em folha de Commelina diffusa, nota-se ainda, o caminho linear (seta) feito pelo minador. Fig. 4.1C: detalhe da larva do minador (Agromyzidae) visto por transparência. Fig. 4.1D: folha minada por (Chironomidae) de Floscopa glabrata; observe as exúvias cefálicas (asterisco) no mesofilo. Ne- Nervura paralela 162

Fig. 4.2A-D - Seções transversais de folhas não minadas de Floscopa glabrata (Fig. 4.2A-B) e Commelina diffusa (Fig. 4.2C-D). Ab- Face abaxial da epiderme; Ad- Face adaxial da epiderme; En- Endoderme; Lc- Parênquima lacunoso; PpParênquima paliçádico; St- Estômatos 163

Fig. 4.3A-F. Seções transversais de folhas minadas de Floscopa glabrata (coluna à esquerda) e Commelina diffusa (coluna à direita). Fig. 4.3A-B: local de entrada $(E)$ da larva minadora. Fig. 4.3C-D: mina $\left(\mathrm{Mi}^{\star}\right)$ formada pelo consumo dos tecidos parenquimáticos. Nota-se unidades vasculares (Uv) não consumidas pelo minador (Fig. 4.3C-D e F). 164 


\section{LISTA DE TABELAS}

Tabela 1. Ensaio histórico do século XIX ao XXI - Diferentes denominações para a região entre o córtex e o cilindro central.

Tabela 2. Nomes atribuídos à endoderme ou às células que a formam. 52 


\section{LISTA DE ABREVIATURAS E SIGLAS}

\begin{tabular}{|c|c|c|c|}
\hline $\mathrm{Ab}$ & abaxial & MEP & meristema de espessamento \\
\hline Ad & adaxial & & primário \\
\hline $\mathrm{Ae}$ & aerênquima & $\mathrm{Me}$ & medula \\
\hline $\mathrm{Ba}$ & bainha foliar & Mf & meristema fundamental \\
\hline $\mathrm{Ca}$ & células com atividade & $\mathrm{Mi}$ & meristema intercalar \\
\hline $\mathrm{Ce}$ & córtex externo & $\mathrm{Mi}^{*}$ & Mina \\
\hline Cf & coifa & $M x$ & metaxilema \\
\hline $\mathrm{Cq}$ & centro quiescente & $\mathrm{Pa}$ & pêlo absorvente \\
\hline Cs & células espessadas & Pc & procâmbio \\
\hline $\mathrm{Ct}$ & córtex & $\mathrm{Pf}$ & protofloema \\
\hline Ctc & córtex do caule & $\mathrm{Pl}$ & plexo periférico/radicular \\
\hline Ctr & córtex da raiz adventícia & $\mathrm{Pm}$ & pró-meristema \\
\hline Cv & cilindro vascular & $\mathrm{Pp}$ & parênquima paliçádico \\
\hline Cx & complexo vascular & $\operatorname{Pr}$ & periciclo \\
\hline \multirow[t]{2}{*}{ DEM } & derivadas da & Px & protoxilema \\
\hline & meristemática & $\mathrm{Ra}$ & raiz adventícia \\
\hline \multirow[t]{2}{*}{$E$} & local de entrada da larva & $S$ & súber \\
\hline & minadora & $\mathrm{Sb}$ & sistema subterrâneo \\
\hline En & endoderme & SCR & scrarecrow (gene) \\
\hline Ep & epiderme & $s c r$ & scrarecrow (mutante) \\
\hline Ev & epivelame & SCR & scrarecrow (proteína) \\
\hline $\mathrm{Fc}$ & feixe caulinar & SHR & short root (gene) \\
\hline Fn & feixe novo & shr & short root (mutante) \\
\hline $\mathrm{Fp}$ & feixes periféricos pericíclicos & SHR & short root (proteína) \\
\hline Fx & feixe da folha & St & estômato \\
\hline $\mathrm{Ga}$ & gema axilar & $\mathrm{Tf}$ & traço foliar \\
\hline $\mathrm{Hp}$ & hipoderme & Uv & Unidade vascular \\
\hline le & inicial endodérmica & Ve & velame \\
\hline Lc & parênquima lacunoso & & \\
\hline i & nite do cilindro vascular & & \\
\hline
\end{tabular}




\section{SUMÁRIO}

AGRADECIMENTOS

LISTA DE FIGURAS

LISTA DE TABELAS

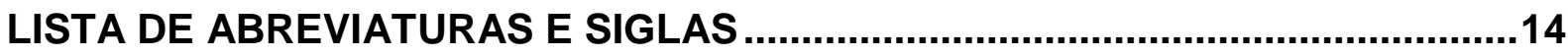

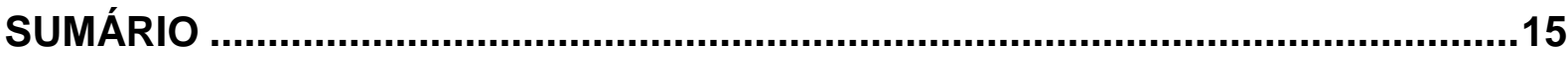

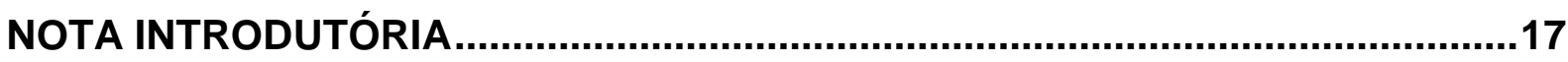

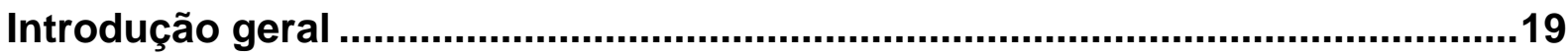

O Espessamento Primário em Monocotiledôneas: ensaio histórico. ................21

Considerações gerais sobre a família Commelinaceae Mirbel ..........................33

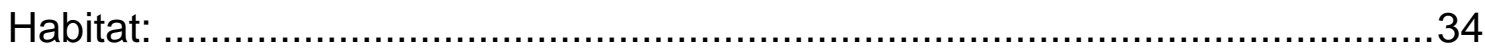

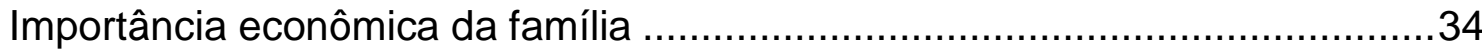

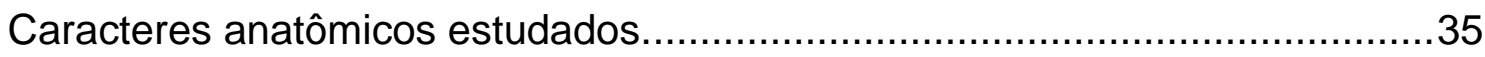

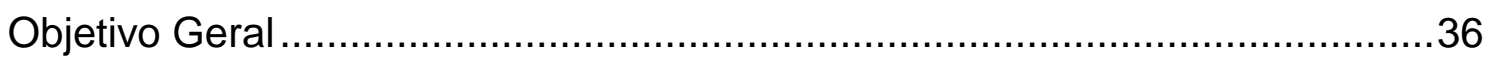

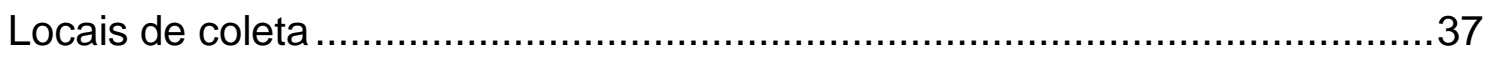

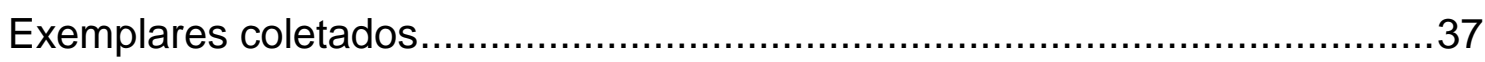

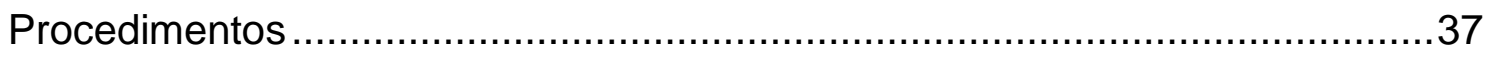

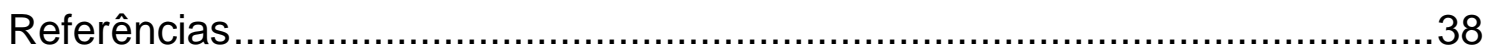

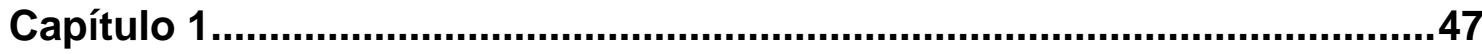

ENDODERME COM ATIVIDADE MERISTEMÁTICA EM RAÍZES DE CINCO

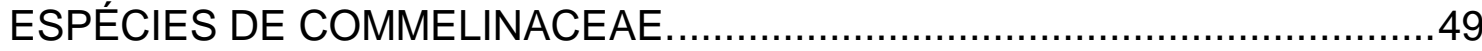

Resumo

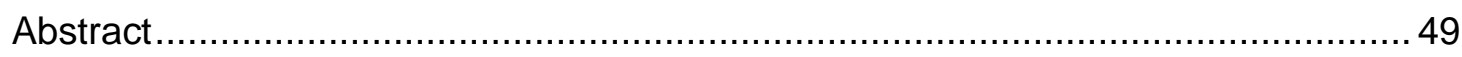

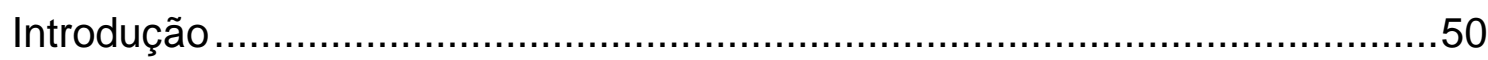

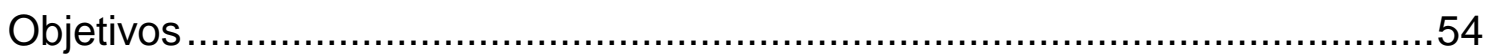

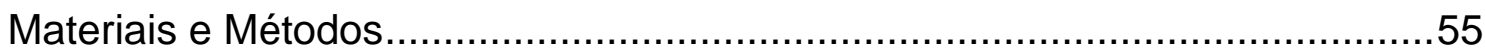

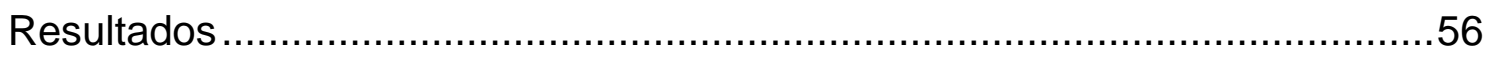

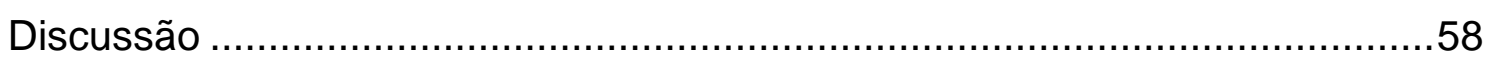

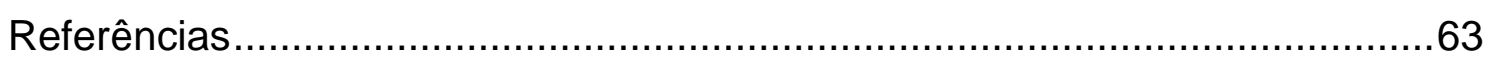

Capítulo 2

SISTEMA CAULINAR EM ESPÉCIES DE COMMELINACEAE ......................79

Resumo

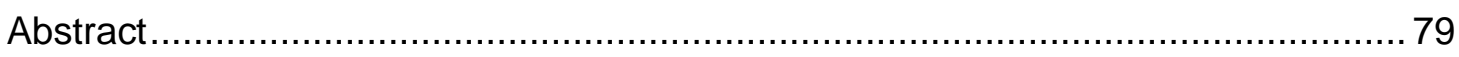

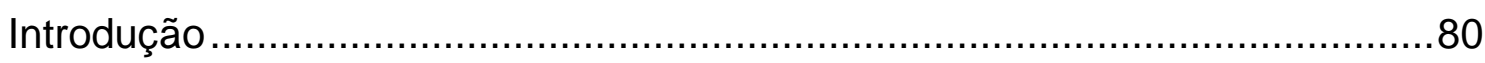

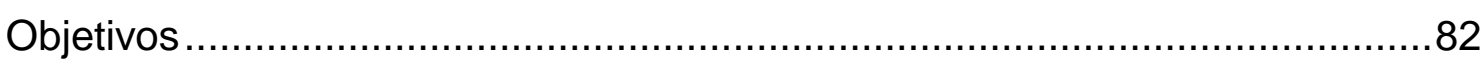




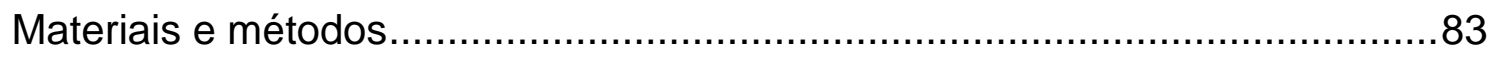

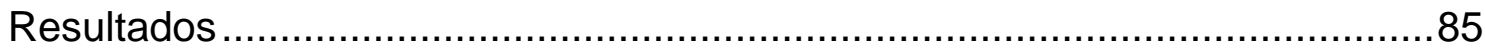

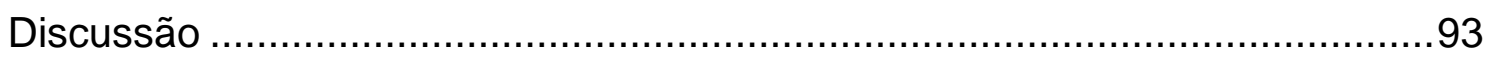

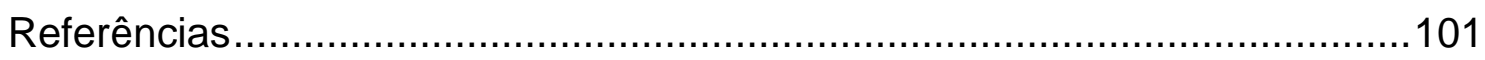

Capítulo 3................................................................................................129

ANATOMIA FOLIAR DE CINCO ESPÉCIES DE COMMELINACEAE

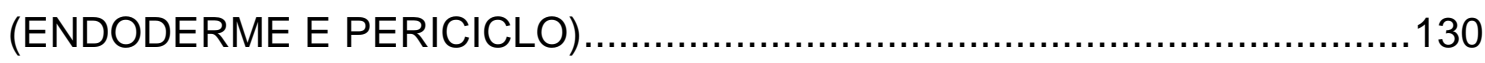

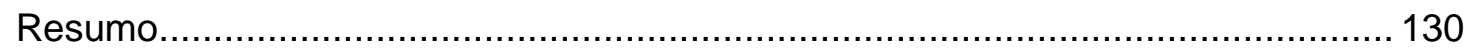

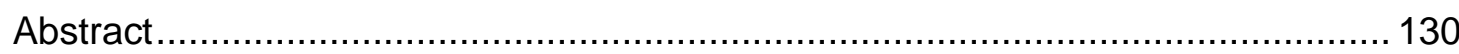

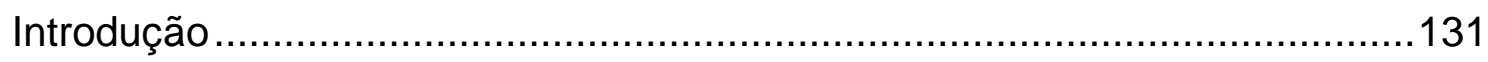

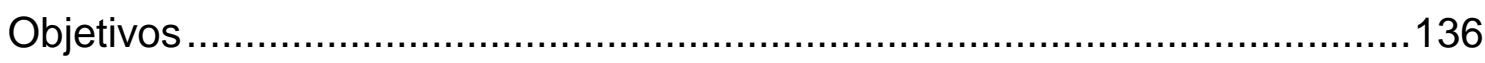

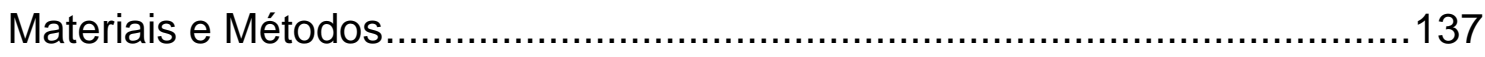

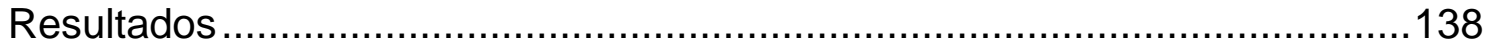

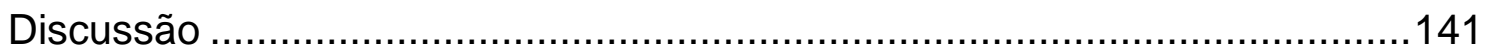

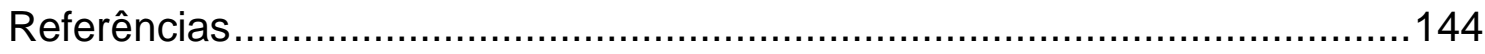

Capítulo 4..................................................................................................151

MORFOLOGIA E ANATOMIA DE MINAS FOLIARES EM COMMELINA

DIFFUSA WILLD. EX. KUNTH E FLOSCOPA GLABRATA (KUNTH) HASSK.

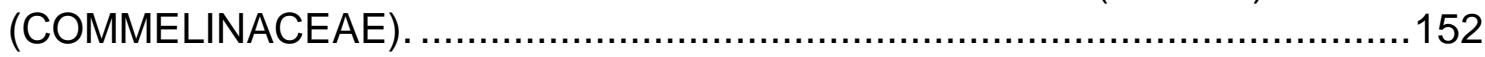

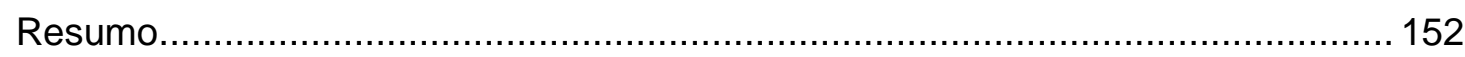

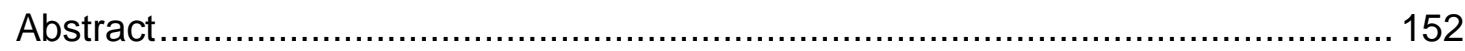

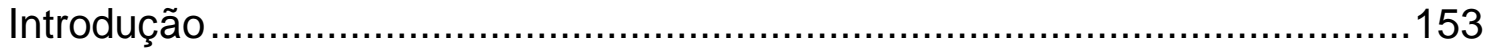

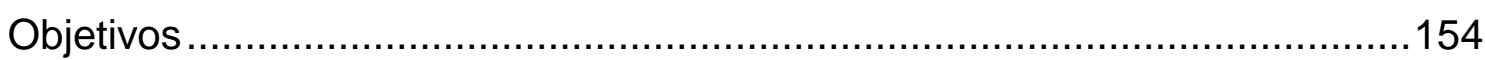

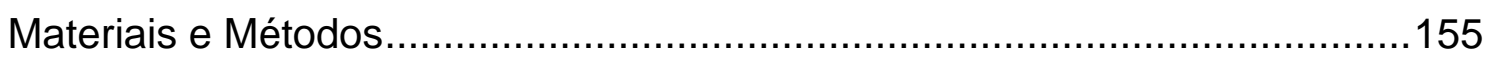

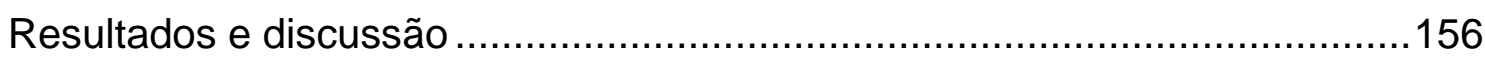

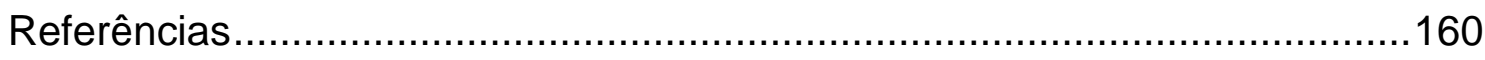

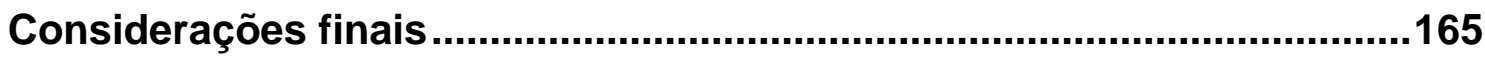

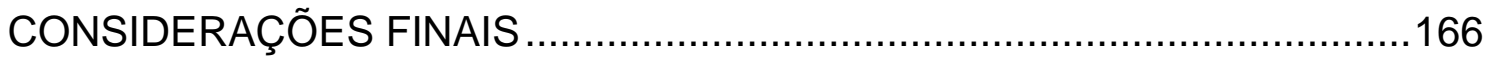




\section{NOTA INTRODUTÓRIA}

Os capítulos desta Dissertação estão organizados em uma seqüência cronológica e topológica, iniciando com uma Introdução geral, a qual enfatiza os primeiros estudos (Século XIX) e dos últimos 50 anos referentes ao espessamento primário em monocotiledôneas - ensaio histórico. Os capítulos I, II e III obedecem à ordem topológica, raiz, caule e folha enfatizando os tecidos: endoderme e periciclo.

A introdução geral aborda as diferentes faces e denominações relacionadas ao espessamento primário, discutidas por diversos autores desde século XIX. O texto mostra ainda, que o principal termo atribuído a este tecido é o MEP (Meristema de Espessamento Primário). Muitos autores acreditam que o MEP promove a formação de tecidos vasculares (função centrípeta) e, também, a formação de parte do córtex (função centrífuga) levando ao espessamento dos sistemas caulinares. Porém, conforme sugerido em trabalho recente, o tecido meristemático que parece ser único, denominado de MEP, na realidade, é composto por dois importantes tecidos, endoderme e o periciclo, ambos em fase meristemática, que atuam na formação do córtex (endoderme) e do cilindro vascular (periciclo), levando ao espessamento do órgão. Além da função meristemática, mostra-se também, que a endoderme e o periciclo estão presentes na raiz, no caule e nas folhas.

Assim, os capítulos I, II e III mostram como estão atuando a endoderme e periciclo nos órgão raiz, caule e folha, respectivamente. O capítulo IV apresenta a mina encontrada nas espécies Floscopa glabrata e Commelina diffusa (espécie não incluída nos estudos relacionados à anatomia da endoderme e periciclo).

O objetivo do presente estudo foi analisar a atividade da endoderme e do periciclo na raiz de Commelina erecta, Dichorisandra tyrsiflora, Floscopa glabrata, 
Tradescantia spathacea e Tradescantia zebrina, assim como, a participação desses tecidos no espessamento primário ou apenas no estabelecimento dos tecidos primários em caules destas cinco espécies. 
INTRODUÇÃO GERAL 



\section{O Espessamento Primário em Monocotiledôneas: ensaio histórico.}

A atividade meristemática no caule de monocotiledôneas, responsável pelo seu espessamento primário, vem sendo alvo de diversos estudos desde o século XIX. Porém, devido a sua versatilidade e a sua grande importância na participação do desenvolvimento do corpo primário de monocotiledôneas, há uma grande diversidade de interpretações e, conseqüentemente, diversas denominações para explicar esse espessamento.

Assim, a presença de uma zona meristemática nos limites entre o cilindro vascular e o córtex, em monocotiledôneas, tem sido reconhecida por muitos autores e recebeu desde o século XIX várias denominações, demonstrado na tabela 1 que apresenta um resumo em ordem cronológica de diferentes denominações dadas a essa região, em diversas famílias e espécies de Monocotiledôneas. Guillaud [36] se refere a este tecido como "périméristème". Da mesma maneira, Mangin [44] notou a presença de um tecido meristemático no limite do cilindro vascular o qual dava origem às raízes adventícias, denominando-o de "couche dictyogéne" (camada geradora de raiz). Segundo este mesmo autor, este tecido especial se comportava de maneiras diferentes entre as monocotiledôneas.

Desta forma, Mangin [44] estabeleceu quatro grupos diferentes, um para cada tipo de atividade apresentado por este tecido meristemático. No primeiro grupo que compreenderiam as monocotiledôneas herbáceas, esse meristema seria responsável pela formação de raízes adventícias e pela formação de plexos vasculares periféricos no cilindro vascular, permanecendo ativo até a formação da raiz. No segundo grupo, que ocorreria em apenas algumas herbáceas, este meristema permaneceria ativo após a formação da raiz, contribuindo para a 
formação do corpo da planta; poderia permanecer ativo por algum tempo ou, até mesmo, durante toda a vida da planta. Ao terceiro grupo pertenceriam plantas arbustivas, cuja ação deste meristema seria complementada, e depois substituída, por um meristema de espessamento secundário. Ao quarto e ultimo grupo pertenceriam as palmeiras, nas quais a camada geradora de raiz dá origem a vários feixes vasculares dispersos no cilindro vascular e depois cessa a atividade.

Nos últimos 50 anos, o espessamento primário de monocotiledôneas tem sido atribuído a um meristema denominado por diversos autores de meristema de espessamento primário (MEP = PTM - Primary Thickening Meristem) $[5,13,16-22$, $24,25,35,54,55,57,58,67-69,84]$

Apesar do MEP ser atribuído, principalmente, às monocotiledôneas, alguns autores reportaram sua presença em diferentes grupos de plantas. Em Licopodiophyta é discutida a presença do MEP em Isoetes ardicola [39] e em Nathorstianella [40]. Em Gimnospermas é relatado para Cycadales [67] e, em Eudicotiledôneas, o MEP é descrito em Bougainville spectabilis [69].

Mais recentemente, Bell [8] menciona a presença de um tecido na interface entre o córtex e o cilindro central, como sendo de particular interesse e que, em muitas monocotiledôneas, seria potencialmente meristemático.

Rudall [58] em seu trabalho de revisão, concluiu e afirmou que o MEP ocorre em todas as monocotiledôneas, sendo encontrado na região do periciclo e que este mesmo meristema é responsável pelo espessamento primário do caule, pela formação de raízes adventícias e pela formação de ligações da vascularização entre raiz e caule e caule e folha. Menezes et al [49] não apenas negam, completamente, a existência do MEP como ainda reconhecem dois tecidos como responsáveis pelo 
espessamento primário em monocotiledônea: o periciclo e a endoderme, ambos com atividade meristemática simulando um único meristema.

Gifford e Bayer [35] atribuem ao MEP, a formação de raízes adventícias e parte do córtex no caule de Cyperus esculentus considerando ser MEP, nesta espécie, a camada translúcida que aparece em secções transversais e longitudinais. Esta mesma camada foi descrita como "camada lúcida" por vários pesquisadores $[41,58,61,65]$. Menezes et al [49] demonstraram que esta camada é resultante da endoderme com atividade meristemática, nos rizomas, e é translúcida antes que suas células formem paredes secundárias lignificadas, constituindo o córtex interno. A essas camadas Menezes et al [49] denominaram de derivadas da endoderme meristemática, abreviadamente, DEM .

DeMason [19], afirmou que a atividade do MEP é típica em monocotiledôneas, especialmente nas que apresentam sistema caulinar espesso e compacto, ou em espécies nas quais a disposição foliar ocorre em rosetas. Além deste caráter morfológico, em seus trabalhos anteriores com Allium cepa, DeMason [16-18] afirmou que este meristema apresenta uma zona de células tangencialmente achatadas entre o córtex e o cilindro vascular que coram com grande intensidade devido ao grande potencial meristemático. Ao acompanhar o desenvolvimento de Allium cepa, DeMason [16] verificou que no sexto mês, células na região do MEP (entre o córtex e o cilindro vascular) tinham se diferenciado em parênquima, em uma rede de tecidos vasculares e ainda, em uma fileira de células espessadas no meio da faixa meristemática, denominada pela autora de "camada endodermóide" a 2,5 $\mathrm{mm}$ acima da base da planta.

Ao estudar a relação entre o MEP e o MES (Meristema de Espessamento Secundário) em Yucca, Diggle e DeMason [21, 24, 25], concluíram que o meristema 
é, desde o ápice, contínuo ao longo de toda planta e que o MEP é precursor do MES. Segundo estes autores, o MEP produz células bidirecionalmente (atividade centrípeta e centrífuga) por divisões periclinais e também está associado à produção de feixes axiais primários e traços foliares. Segundo Menezes et al [49] esta é a mais uma evidência de se estar diante de dois meristemas: a endoderme meristemática formando parênquima cortical centrifugamente e o periciclo formando tecido vascular centripetamente. Exatamente como afirmavam os pesquisadores do século XIX, sempre atribuindo os tecidos vasculares do caule e as raízes adventícias como de origem do periciclo que por sua vez, seria de origem procambial e que todo córtex teria origem do meristema fundamental. Por outro lado, os feixes "primários" (além dos traços foliares) foram verificados por Menezes [46, 47] em Velloziaceae como sendo de origem de procâmbio. Além do mais, a autora demonstra que traços foliares seriam formados por protoxilema e metaxilema, protofloema e metafloema e que os outros feixes seriam os feixes caulinares formados, unicamente, de metaxilema e metafloema.

Portanto, segundo diferentes autores, o MEP pode ter função somente centrífuga (só forma parte do córtex) como em Cyperus esculentus [35]; função somente centrípeta (forma somente tecido vascular) ou pode ter atividade centrípeta e centrífuga; estas duas últimas atividades, como demonstra Rudall [58] em seu trabalho de revisão citando vários autores, entre eles, Diggle e DeMason [21, 24, 25].

Segundo Rodrigues e Estelita [55], em Cyperus giganteus, o parênquima cortical interno, as raízes adventícias, a endoderme, o periciclo e feixes vasculares anfivasais são originados do MEP. Porém, para a maioria dos autores [26, 33, 36, 44, 47, 49] desde o século XIX, a origem do periciclo e da endoderme se dá, 
respectivamente, a partir do procâmbio e do meristema fundamental e, formam, respectivamente, o cilindro vascular e o córtex.

Com relação às raízes, apesar de vários autores desde o século XIX demonstraram em suas representações anatômicas camadas radiadas no córtex, como por exemplo, Troll [74] (pág. 325) cuja primeira edição é de 1897 e em Van Tieghem em 1898 [79], foi Williams [81] o pioneiro a demonstrar que estas camadas são resultantes de uma endoderme com atividade meristemática. $\mathrm{O}$ autor se refere a "células cambiais". Segundo este mesmo autor, nas plantas vasculares, a endoderme é responsável pela origem dos tecidos primários do córtex (ou de parte do córtex) das raízes, originando células em disposição radiada. Este estudo foi realizado em raízes de 74 famílias de Monocotiledôneas, 105 de Dicotiledôneas, 5 de Gimnospermas e 11 de Pteridófitas. Os resultados mostraram que em todos os casos, exceto para algumas pteridófitas, a endoderme pelo autor denominada com atividade cambial, originou tecidos entre a endoderme e a hipoderme (camada mais interna e mais externa do córtex, respectivamente).

Os estudos de Williams [81] foram bem referendados por Van Fleet [77], que sugere como sinonímia para endoderme com atividade cambial, o termo próendoderme utilizado por Hurst (1956 apud Van Fleet 76). Menezes et al [49] optam pelo termo "endoderme com atividade merismática", utilizando a denominação de "inicial endodérmica" quando ela se encontra em fase de divisão. Recentemente, estudos de pesquisadores da genética molecular do desenvolvimento atribuíram à endoderme da raiz o termo: inicial endodérmica ("endodermal initial"). Este termo foi adotado devido à capacidade de divisão da endoderme para formar camadas radiadas no córtex, pela presença de dois genes que regulam este mecanismo, o gene SCARECROW e o gene SHORT- ROOT [15, 23, 34, 63]. Além disso, estudos 
recentes [15] com genes homólogos SHR e SCR em arroz (Oryza sp.) sugerem que este mecanismo é evolutivamente conservado, dando uma plausível explicação do porquê de todas as plantas apresentarem uma única camada na endoderme.

O termo endoderme meristemática também foi utilizado para raiz por Mellode-Pinna e Menezes [45], em estudo que revelou que a raiz de lanthopappus corimbosus (Asteraceae), apresenta córtex radiado. Machado et al [43] fizeram o mesmo com relação à Smallanthus sonchifolius (Asteraceae) e Alonso et al [1], para Canna edulis e Alves e Menezes [4] em Scleria (Cyperaceae).

Em trabalhos recentes, o termo proendoderme foi usado para raízes por Mueller [51] e Seago Júnior et al [64]. Este último trabalho refere-se à próendoderme como sendo a camada mais interna, resultante de divisões periclinais das células do córtex de Hydrocharis morsus-ranae.

Van Fleet [75] apresentou uma relação da distribuição da endoderme em caule de 17 famílias de monocotiledôneas. Entre as famílias estudadas, a das Commelinaceae, incluindo as seguintes espécies: Tradescantia crassula, T. áureostriata. T.reflexa, T. fluminensis, Zebrina pendula, Commelina virginica e Rhoeo discolor.

Recentemente Pizzolato [54] atribuiu ao MEP o aumento do diâmetro do disco no caule e também a sua contribuição na formação de tecidos vasculares caulinares e traços foliares em Tradescantia zebrina (Commelinaceae). Neste trabalho o autor demonstrou a presença de endoderme e, o tecido adjacente a ela, formando novos feixes, é por ele denominado MEP. Por outro lado, Alves et al [3] , na espécie Rhoeo spathacea demonstraram, ser este tecido meristemático, na realidade, o periciclo, adjacente a uma endoderme com estrias de Caspary. 
Um problema em relação à endoderme é a dificuldade que os pesquisadores têm para notarem a presença deste tecido em caule e folha. Em raiz, evidenciá-la é simples, pois, em geral, a presença de estrias de Caspary torna a endoderme perfeitamente visível e qualquer livro texto sempre demonstra essa presença em raízes. Van Fleet [77] em sua revisão deixa claro que através de testes histoquímicos a endoderme é perceptível em caule e folhas. De acordo com este autor, na raiz e em caules subterrâneos a endoderme pode ser caracterizada pela presença de estrias de Caspary, células suberificadas, presença de substâncias fenólicas, cristais ou com depósito unilateral de celulose; em caules aéreos, o mesmo autor demonstra que, em geral, estrias de Caspary e/ou bainha amilífera é que são mais comuns.

Em folhas, Van Fleet [77] demonstra a presença de endoderme com estrias de Caspary em folhas de Poaceae e Cyperaceae, mas Menezes et al [48] demonstram a presença de estrias de Caspary em pecíolos e lâminas foliares em Pteridófitas, Gimnospermas, Monocotiledôneas e Eudicotiledôneas. Esau [26] (p. 441) com base nos trabalhos de Van Fleet afirma que "a bainha do feixe da folha das angiospermas é a endoderme".

Para Van Fleet [77], o mais importante é reconhecer que a endoderme é a camada mais interna do córtex da raiz, do caule, e da folha e também a camada mais interna do mesofilo na lamina foliar. Na realidade, Van Fleet [77] define a endoderme mais pela sua função do que por sua característica anatômica. Holm [37] descreveu a anatomia de folhas de seis gêneros de Rubiaceae, onde quatro espécies de Galium tinham endoderme com estrias de Caspary em estruturas aéreas, isto é, no caule e na folha. 
Lersten [42] concluiu em sua revisão que, apesar da distribuição de endoderme com estrias de Caspary em caule e na folha ser irregular entre as plantas vasculares, ela ocorre. Em Pteridófitas é encontrada também em rizomas e fronde; em caule de Gimnospermas, segundo esse autor, é ausente, mas presente em folhas de algumas coníferas, fato observado, recentemente, por $\mathrm{Wu}$ [83] em Pinus bungeana. Takeda [70] demonstra a presença de em Cycas e Podocarpus.

Para Lersten em angiospermas herbáceas a endoderme aparece no caule, mas é pouco comum em folhas. Para Van Fleet [77] como já foi visto e para Menezes et al [49], a endoderme está sempre presente como a camada mais interna do córtex da raiz, do caule, do pecíolo da folha e, também, como a camada mais interna do mesofilo da lâmina foliar. Ainda segundo Menezes [47] e Menezes et al [49] todos os tecidos primários que estão na raiz estão no caule e estão nas folhas com uma perfeita continuidade entre raiz e caule, e entre caule e folha. Menezes et al [49] demonstraram, também, a presença de células resultantes de uma endoderme com atividade meristemática em folhas de Echinodorus paniculatus.

A continuidade entre a endoderme do caule e a endoderme da folha foi demonstrada por Menezes [47] em estudos do deslocamento do traço foliar do interior do cilindro vascular, até a folha. A autora verificou que o traço, ao ultrapassar a endoderme do caule, atravessa o córtex envolvido por essa endoderme indo constituir a endoderme da própria folha. A autora demonstra também que o mesofilo da folha é o próprio córtex caulinar modificado. Como já foi visto, neste mesmo trabalho a autora demonstra que o procâmbio forma dois tipos de feixes: traços foliares, os únicos que possuem protoxilema e protofloema (além de metaxilema e metafloema) e feixes caulinares (os que são formados unicamente de metaxilema e metafloema). Em trabalho aceito para publicação [2] as autoras demonstraram que o 
periciclo, além de tecido gerador de feixes vasculares em continuidade ao procâmbio, forma unicamente feixes caulinares, isto é, constituídos de metaxilema e metafloema. O periciclo é definido por Menezes et al [49] como a camada geradora de tecidos vasculares em continuidade à atividade do procâmbio.

Vieira et al [80] reconheceram que a bainha do feixe em folhas de Cryptochloa capillata, Raddia brasilienses e Pharus lappulaceus (Poaceae: Bambusoideae) é a endoderme por ser a camada mais interna do córtex.

Tomlinson [72] descreve o limite interno do córtex no caule de Commelinaceae como uma camada distinta de células parenquimáticas unisseriadas com depósito de amido, esclarecendo ser esta camada comumente descrita como a endoderme, porém a falta de estrias de Caspay torna o termo endoderme para ele conflitante, chamando-a de "camada endodermóide", embora reconheça que outras famílias possam apresentar endoderme verdadeira.

Apesar da diferente abordagem, estudos genéticos $[34,50]$ mostram também a presença da endoderme no caule e no que os autores chamam de bainha do feixe da folha em Arabidopsis thaliana. Estes trabalhos demonstraram que a endoderme no caule é essencial para a percepção da gravidade, uma vez que, amiloplastos são encontrados na camada mais interna do córtex $[59,60]$ e, esta camada é a endoderme, também chamada de bainha amilífera. 
Tabela 1. Ensaio histórico do século XIX ao XXI - Diferentes denominações para a região entre o córtex e o cilindro central.

\begin{tabular}{|c|c|c|}
\hline Autor & Família /Espécies estudadas & $\begin{array}{c}\text { Nome dado pelo autor à região localizada entre o córtex e o } \\
\text { cilindro vascular } \\
\text { "Cambium ring" - (anel cambial). }\end{array}$ \\
\hline$\underset{\text { [62] }}{\mathrm{SCHACHT}} 1852$ & Pandanus e Dracaena & $\begin{array}{l}\text { Segundo SCHACHT entre a medula e o córtex de todas as plantas vasculares, são } \\
\text { encontradas células em divisão. Ele denominou esta região de "cambium ring" - } \\
\text { (anel cambial), este anel lignificado é encontrado em monocotiledôneas que } \\
\text { apresentam um espessamento considerável do caule, como Pandanus e } \\
\text { Dracaena. }\end{array}$ \\
\hline $\begin{array}{l}\text { (SANIO 1864 } \\
\text { apud[44]) }\end{array}$ & Dracena & $\begin{array}{l}\text { "Verdickungring" - (Anel de espessamento) } \\
\text { Relata em Dracena a existência de uma região como um tecido divisor ou ainda } \\
\text { anel de espessamento, formando feixes centripetamente- em alemão - } \\
\text { Verdickungring. }\end{array}$ \\
\hline
\end{tabular}

"Périméristème"- (Perimeristema)

Cannaceae

$1878[36] \quad$ Commelinaceae (Trade

Convallariaceae

Estabeleceu que no caule de todas as monocotiledoneas, ocorre uma zona geradora que aparece entre os limites do córtex e cilindro central. Em Tradescantia virginica a bainha é freqüentemente envolvida, por fora, por 10-15 células produzidas pelas divisões tangenciais realizadas pelo périméristème e até mesmo dispostos radialmente.

$\begin{array}{ccc}\text { MANGIN } 1882 & \begin{array}{c}\text { "Couche dictyogéne" - (Camada geradora de raiz) } \\ \text { Valias familias Asphodelaceae, } \\ \text { Iridaceae, Ruscaceae e } \\ \text { Araceae }\end{array} & \begin{array}{l}\text { Notou a presença de um tecido meristemático o qual originaria raízes adventícias, } \\ \text { eque se localizava na periferia do cilindro vascular. Este tecido foi denominado por } \\ \text { este autor de "couche dictyogéne". Segundo este mesmo autor, este tecido } \\ \text { especial se comportava de maneiras diferentes entre as monocotiledôneas. }\end{array}\end{array}$

PETERSEN

1892-1893 apud

[69]

Várias famílias

"Primary Thickening Meristem" - (Meristema de Espessamento Primário)

Em 1892 este autor referiu-se à região meristemática encontrada entre o córtex e o cilindro vascular como Zona intemediária.

Em 1893 apesar da grande maioria dos pesquisadores do século XIX não terem mencionado, PETERSEN foi o primeiro autor a se referir a um meristema de espessamento primário.

\section{"Zone génératice" - (Zona geradora)}

VAN TIEGHEM
$1897[78]$
Em seu trabalho com anatomia de Araceae, encontrou uma zona geradora de feixes denominada por ele de "zone génératice", a qual ocupa a periferia do caule e esta é circundada pela endoderme.

\section{"Cambial zone" - (Zona cambial)}

CHEADLE $1937 \quad$ Liliaceae, Amarylidaceae

[13]
De acordo com o autor, o corpo secundário é composto por tecidos produzidos por uma camada periférica ou uma camada de células meristemáticas. De acordo com CHEADLE (1937) o espessamento secundário no caule é ocasionado por uma "zona cambial". Porém, segundo o mesmo autor não é possível determinar qual é a região que origina esta zona: se, é a camada interna do córtex ou o periciclo.

\begin{tabular}{ccc}
$\begin{array}{c}\text { CHAKRAVERT } \\
\text { (1938) } \\
\text { [12] }\end{array}$ & Curcuma longa & $\begin{array}{c}\text { "Fugacius cambium" - (Câmbio temporário) } \\
\text { A atividade cambial é limitada a uma região muito curta da sua parte apical, esta } \\
\text { região ele a denominou como "Fugacius cambium". }\end{array}$ \\
$\begin{array}{c}\text { BALL 1941 } \\
\text { [5] }\end{array}$ & Pheonix canariensis & $\begin{array}{l}\text { "Primary Thickening Meristem" - (Meristema de Espessamento Primário) } \\
\text { Quase meio século após PETERSEN (1893), foi um dos pioneiros nas últimas } \\
\text { décadas a usar o termo Meristema de Espessamento Primário (MEP); ele concluiu } \\
\text { que no crescimento das palmeiras o MEP contribui primeiro para o aumento do } \\
\text { diâmetro do caule e depois para a altura do mesmo. }\end{array}$ \\
\hline
\end{tabular}




\begin{tabular}{|c|c|c|}
\hline $\begin{array}{c}\text { KRAUSS } 1948 \\
{[41]}\end{array}$ & Ananas comosus & $\begin{array}{l}\text { "Dictyogenous layer" - .(Camada geradora de raíz) } \\
\text { Encontrou uma região meristemática entre o córtex e o estelo, a qual denominou } \\
\text { de camada dictiogênica- "dictyogenous layer".citando MANGIN. }\end{array}$ \\
\hline $\begin{array}{l}\text { VAN FLEET } \\
1950 \\
{[76]}\end{array}$ & & $\begin{array}{l}\text { "Parenchyma-Vascular Boundary" - Parênquima vascular } \\
\text { Com estudos bioquímicos Van Fleet demonstra que a endoderme está presente } \\
\text { em órgãos aéreos, como caule e folha. }\end{array}$ \\
\hline $\begin{array}{c}\text { TOMLINSON \& } \\
\text { ZIMMERMAN } \\
\text { (1969) } \\
\text { [73] }\end{array}$ & Arecaceae & $\begin{array}{l}\text { "Cap meristem" - (Meristema em calota). } \\
\text { Referindo ao ápice das palmeiras, os autores denominaram esta região como } \\
\text { meristema em calota "cap meristem". Segundo o autor o MEP localiza-se } \\
\text { imediatamente abaixo da calota. Menezes por sua vez admite que o meristema em } \\
\text { calota nada mais é que as DEM e que portanto internamente a elas estaria o } \\
\text { periciclo. }\end{array}$ \\
\hline
\end{tabular}

\section{BENDIXEN}

(1973) [9]

Cyperus esculentus

Estabelece que as raízes são originadas no periciclo.

\begin{tabular}{|c|c|c|}
\hline & & "Primary Thickening Meristem" - (Meristema de espessamento primário) \\
\hline $\begin{array}{c}\text { DEMASON } \\
1979-1983 \\
{[16-19]}\end{array}$ & Allium cepa & $\begin{array}{l}\text { Afirma que este meristema apresenta uma zona de células tangencialmente } \\
\text { achatadas entre o córtex e o cilindro vascular que coram com grande intensidade } \\
\text { devido ao grande potencial meristemático. Ao acompanhar o desenvolvimento de } \\
\text { Allium cepa, DeMason [16, 17] verificou que no sexto mês, células na região do } \\
\text { MEP (entre o córtex e o cilindro vascular) tinham se diferenciado em uma camada } \\
\text { por ela denominada endodermóide (parênquima espessado) e em uma rede de } \\
\text { tecidos vasculares a } 2,5 \mathrm{~mm} \text { acima da base da planta [16-18] }\end{array}$ \\
\hline
\end{tabular}

\section{Não apresentou nomes}

BELL 1980 [8]
Alpinea speciosa

(pinea speciosa

Este autor menciona a presença de um tecido na interface, entre o córtex e o cilindro central, como sendo de particular interesse e, em muitas monocotiledôneas, seria potencialmente meristemático.

WILLS et al. $\quad$ Cyperus esculentus $\quad$ Relata que raízes de Cyperus são originadas na endoderme.
1980 [82]

"Primary Thickening Meristem" - (Meristema de Espessamento Primário)

\begin{tabular}{|c|c|c|}
\hline $\begin{array}{c}\text { DIGGLE } 1983 \\
{[24,25]}\end{array}$ & Yucca whipplei, & $\begin{array}{l}\text { Encontraram que em Yucca whipplei,tanto a formação de raiz como a formação de } \\
\text { feixes vasculares secundários ocorrem no Meristema de espessamento secundário } \\
\text { (MES), visto que o MEP é o local de produção de feixes vasculares primários e } \\
\text { traços foliares, embora a transição entre estes dois meristemas seja gradual. } \\
\text { Diggle e DeMason concluem que estes dois meristemas são ontogeneticamente } \\
\text { idênticos. }\end{array}$ \\
\hline
\end{tabular}

\begin{tabular}{|c|c|c|}
\hline & & "Primary Thickening Meristem" - (Meristema de Espessamento Primário) \\
\hline $\begin{array}{l}\text { RUDALL } 1984 \\
{[56]}\end{array}$ & Iridaceae & $\begin{array}{l}\text { Conclui que em células da junção entre o córtex e o cilindro vascular são sempre } \\
\text { potencialmente meristemáticas, assim como, a região do MEP próxmo ao ápice do } \\
\text { caule e o local de iniciação de primórdios radiculares. }\end{array}$ \\
\hline
\end{tabular}

"Primary Thickening Meristem" - (Meristema de Espessamento Primário)

RUDALL 1991

[58]

Revisão

A revisão sobre o Espessamento primário e secundário em caule de Monocotilêdoneas realizada por RUDALL em 1991 demonstra que diversos autores admitem que o Meristema de espessamento primário (MEP) corresponde à região do periciclo.

\section{"Primary Thickening Meristem" - (Meristema de Espessamento Primário)}

O MEP pode ter função somente centrífuga (só forma parte do córtex) como é o que o autor admite em Cyperus esculentus.

Com certeza, segundo Menezes et al [49] ele estaria falando das DEM. Na ausência de estria de Caspary, esta camada é chamada pelo autor de 
endodermóide. O preciso local de origem do primórdio de raiz no Mep de Cyperus esculentos segundo o autor é na camada lúcida. Em níveis inferiores do cormo em desenvolvimento, as paredes das células da camada interna do MEP são mais espessas do que aquelas das outras células. $E$ isto pode ser interpretada como endoderme.

\section{RODRIGUES \& \\ ESTELITA 2002 \\ [55]}

"Primary Thickening Meristem" - (Meristema de Espessamento Primário)

Em Cyperus giganteus, como em outras monocotiledôneas, a partir do promeristema do rizoma diferenciam-se a protoderme, o procâmbio e o meristema fundamental e, ainda, o meristema de espessamento primário (MEP). Este último dá origem ao parênquima cortical interno, endoderme, periciclo e feixes vasculares anfivasais, os quais se formam também a partir do procâmbio. Após a diferenciação do corpo primário, apenas o periciclo permanece em divisão, formando um sistema vascular desalinhado, onde os elementos de vaso são mais curtos e mais ramificados do que aqueles do crescimento primário. Esta mudança de atividade do periciclo caracteriza o crescimento secundário, cujo meristema de espessamento (MES) é o próprio periciclo.

\begin{tabular}{|c|c|c|}
\hline $\begin{array}{c}\text { MENEZES } 2005 \\
{[49]}\end{array}$ & $\begin{array}{c}\text { Cephalostemon riedelianus } \\
\text { (Rapataceae), Cyperus } \\
\text { papyrus, Lagenocarpus rigidus, } \\
\text { L. junciformis (Cyperaceae), } \\
\text { Echinodorus paniculatus } \\
\text { (Alismataceae) } \\
\text { Zingiber officinale } \\
\text { (Zingiberaceae). }\end{array}$ & $\begin{array}{l}\text { Apresentou uma nova interpretação para explicar o espessamento primário em } \\
\text { monocotiledôneas. Esse espessamento primário resulta da atividade do periciclo } \\
\text { ou do periciclo associado à endoderme com atividade meristemática em } \\
\text { substituição à idéia da presença de MEP. }\end{array}$ \\
\hline $\begin{array}{l}\text { PIZZOLATO } \\
2006 \\
{[54]}\end{array}$ & $\begin{array}{c}\text { Tradescantia zebrina } \\
\text { (Commelinaceae) }\end{array}$ & $\begin{array}{l}\text { Primary Thickening Meristem - (Meristema de Espessamento Primário) } \\
\text { Próximo ao ápice o espessamento do órgão, bem como, a formação de traços } \\
\text { foliares é dada pelo PTM. }\end{array}$ \\
\hline
\end{tabular}




\section{Considerações gerais sobre a família Commelinaceae Mirbel}

Commelinaceae é um grupo bem definido com 41 gêneros e 650 espécies [14, 27-30, 32]. Entretanto, a filogenia não é bem sustentada tendo sido feita com apenas um marcador molecular e, além disso, os autores não apresentam em nenhum momento árvores de consenso [28].

Commelinaceae está dividida em duas subfamílias: Cartonematoideae e Commelinoideae. A subfamília Commelinoideae está dividida em duas tribos monofiléticas Commelinae e Tradescantiae. Commelinae apresenta dois gêneros do presente estudo: Commelina erecta L., e Floscopa glabrata (Kunth) Hassk.; as espécies Dichorisandra tyrsiflora (Aubl.) Standl., Tradescantia spathacea Swartz e Tradescantia zebrina Hort. Ex Loud. pertencem à tribo Tradescantiae [28].

A família tem seus representantes conhecidos pelo nome vulgar de "trapoeraba" e caracteriza-se por diversos aspectos incluindo uma bainha da folha fechada, lâmina foliar suculenta, flores trímeras com pétalas e sépalas distintas, caules herbáceos, às vezes suculentos, e comumente rizomatosos [7, 14, 28-30, 32, 38, 72]. Os gêneros são tropicais, subtropicais e diversos gêneros se estendem a regiões temperadas. A maior diversidade está na África, onde, somente em Madagascar encontra-se, aproximadamente, metade dos gêneros e $40 \%$ das espécies [31].

Há uma divisão natural entre os taxa do Velho e Novo Mundo. As sete subtribos da tribo Tradescantieae (sensu Faden e Hunt [32]) são completamente confinadas no Leste ou Oeste do hemisfério, embora a tribo Commelineae seja encontrada principalmente na África e na Ásia. Somente 
seis gêneros (Aneilema, Buforrestia, Commelina, Floscopa, Murdania e Pollia) têm espécies nos dois hemisférios [27].

O maior gênero é Commelina (230 spp.) seguido de Tradescantia (60 spp.), Aneilema (60 spp.), Murdannia (45 spp.) e Callisia (20 spp.) [38].

\section{Habitat:}

Esta família possui ampla tolerância ecológica, podendo assim colonizar diversos ambientes. Segundo Evans et al [28], os gêneros Commelina, Floscopa e Tradescantia são plantas de habitat abertos e Dichorisandra apresenta hábito florestal. No Brasil ocorrem 13 gêneros nativos, Aneilema, Buforrestia, Callisia, Commelina, Dichorisandra, Floscopa, Geogenanthus Gibasis, Murdannia, Sirderasis, Tinantia, Tradescantia (=Campelia, Rhoeo, Setcreasea, Zebrina e Tripogandra), abrangendo cerca de 60 espécies [66].

\section{Importância econômica da família}

A importância econômica da família está no fato de algumas espécies serem plantas invasoras, outras terem utilização ornamental e algumas possuírem potencialidades medicinais [53]. Em áreas agrícolas, estas plantas provocam prejuízos econômicos causados pela concorrência por nutrientes, água e luz. Possuem alto teor de água no caule, o que pode dificultar, em muito, a colheita dos grãos devido ao mofo e, ainda, podem hospedar insetos que prejudicam o pleno desenvolvimento da lavoura [52]. As plantas que mais infestam as colheitas pertencem ao gênero Commelina. 


\section{Caracteres anatômicos estudados.}

Os caracteres anatômicos têm sido considerados esporadicamente. Brückner [11] examinou em um amplo estudo a anatomia de folhas, mas apenas encontrou caracteres estomáticos para serem utilizados para a subdivisão da família. Tomlinson em 1966 [71] checou a distribuição dos tipos de tricomas e caracteres anatômicos de folhas em gêneros de grupos informais introduzidos por Brenan [10] e encontrou somente uma congruência parcial. Faden e Hunt [32] dividiram a família em duas subfamílias Cartonematoideae e Commelinoideae baseado, principalmente, nas diferenças dos padrões de distribuição dos canais de ráfides e na presença e ausência de tricomas glandulares. A circunscrição da Cartonematoideae foi recentemente suportada por Baker et al [6]. A subdivisão sugerida por Faden e Hunt [32] da grande subfamília Commelinideae é baseada, principalmente, na organização dos complexos estomáticos e na estrutura da exina do pólen. Mais recentemente, Evans et al [27] comparou dois cladogramas gerados por seqüência de rbcL e um cladograma com dados morfológicos e anatômicos. 


\section{Objetivo Geral}

Existem poucos relatos sobre a anatomia de órgãos vegetativos de Commelinaceae. O objetivo deste trabalho é analisar anatomicamente os órgãos vegetativos das seguintes espécies: Commelina erecta, Dichorisandra tyrsiflora, Floscopa glabrata, Tradescantia spathacea e Tradescantia zebrina. Assim, pretende-se verificar-se-á se na família Commelinaceae também podem ser encontrados mais elementos que corroborem com o postulado de Menezes et al [49] em que o espessamento primário em monocotiledôneas resulta da atividade do periciclo associado à endoderme com atividade meristemática em substituição à idéia da presença de MEP. Tais objetivos admitem-se alcançar estudando os meristemas apicais do caule através do entendimento de que a planta é uma unidade, conforme postulado pelas autoras acima. Além disso, demonstrar a presença desses tecidos (endoderme e periciclo) nos diferentes órgãos vegetativos. 


\section{Locais de coleta}

As coletas foram realizadas em dois locais. O primeiro local foi no Parque Nacional da Serra do Cipó, Minas Gerais (19¹8'53,9"' S; 43³5'47,9’W), situada na Cadeia do Espinhaço, entre os municípios de Santana do Riacho e Conceição de Mato Dentro. O segundo local foi nos jardins do Instituto de Biociências da Universidade de São Paulo (23॰33'45,24'S; 4643'54,71'’W).

\section{Exemplares coletados}

\begin{tabular}{ccc}
\hline Local & Serra do Cipó & Instituto de Biociências (USP) \\
& Commelina erecta L. & Tradescantia spathacea Sw. \\
Espécies & Floscopa glabrata (Kunth) Hassk & Tradescantia zebrina Hort. Ex Loud. \\
& & Dichorisandra tyrsiflora (Aubl.) Standl \\
\hline
\end{tabular}

\section{Procedimentos}

Os procedimentos serão descritos em cada capítulo. 


\section{Referências}

[1] ALONSO, A. A.; MORAES-DALLAQUA, M. A.; DE MENEZES, N. L. 2004. Endoderme com atividade meristemática em raiz de Canna edulis Kerr-Gawler (Cannaceae). Acta Botanica Brasilica, v.18, n.3.

[2] ALVES, V. F. G.; MENEZES, N. L. D. 2008. Morpho-Anatomical Analysis of the Rhizome in Species of Scleria Berg. (Cyperaceae) from Serra do Cipó (MG). Brazilian Archives of Biology and Technology.

[3] ALVES, V. G.; MELO-DE-PINNA, G. F.; ARRUDA, R. C.; SILVA, C. G.; SCREMIM DIAS, E.; MENEZES, N. L. Pericycle and endodermis in monocotyledons. In: Abstracts: XVII International Botanical Congress, 2005, Vienna, Austria, Europe.

[4] ALVES, V. G.; MENEZES, N. L. D. 2008. Endodermis with meristematic activity in roots of species of Scleria Berg. (Cyperaceae). Revista Brasileira de Botânica, v.no prelo.

[5] BALL, E. 1941. The development of the shoot apex and of the primary thickening meristem in Phoenix canariensis Chaub., with comparisons to Washingtonia filifera Wats. And Trachycarpus excelsa Wendl. American Journal of Botany, v.28, n.9, p.820-832.

[6] BARKER, N. P.; B, F. R.; BRINK, E.; DOLD, A. P. 2001. Notes on African Plants: Commelinaceae: rediscovery of Triceratella drummondii, and comments on its relationships and position in the family. Bothalia, v.31, p. 37-39.

[7] BARRETO, R. C. Levantamento das espécies de Commelinaceae R. Br. nativas do Brasil 1997, 490 p f, Universidade de São Paulo, São Paulo.

[8] BELL, A. 1980. The vascular pattern of a rhizomatous Ginger (Alpinia speciosa L. Zingiberaceae). 2. The rhizome. Annals of Botany, v.46, n.2, p.213-220.

[9] BENDIXEN, L. E. 1973. Anatomy and sprouting of yellow nutsedge tubers. Weed Science, v.21, n.6, p.501-503.

[10] BRENAN, J. P. M. 1966. The classification of Commelinaceae. Botanical Journal of the Linnean Society, v. 59, p. 349-370. 
[11] BRÜCKNER, G. 1926. Beiträge zur Anatomie, Morphologie und Systematik der Commelinaceae. Beiblattzu den Botanischen Jahrbüchern., v.61, p.1-70.

[12] CHAKRAVERTI, D. N. 1939a. The occurrence of fugacious cambium in the rizoma of Curcuma longa L. The Philippine Journal of Science, v.69, p.191195.

[13] CHEADLE, V. I. 1937. Secondary growth by means of a thickening ring in certain Monocotyledons. Botanical Gazette, v.98, n.3, p.535-555.

[14] CRONQUIST, A., 1981. The Evolution and Classification of Flowering Plants. 2 ed. New York: Columbia University Press, The New Botanical Garden. 1260 p.

[15] CUI, H.; LEVESQUE, M. P.; VERNOUX, T.; JUNG, J. W.; PAQUETTE, A. J.; GALLAGHER, K. L.; WANG, J. Y.; BLILOU, I.; SCHERES, B.; BENFEY, P. N. 2007. An evolutionarily conserved mechanism delimiting SHR movement defines a single layer of endodermis in plants. Science, v.316, n.5823, p.421425.

[16] DEMASON, D. A. 1979. Function and development of the primary thickening meristem in the Monocotyledon, Allium cepa L. Botanical Gazette, v.140, n.1, p. 51-66.

[17] DEMASON, D. A. 1979. Histochemistry of the primary thickening meristem in the vegetative stem of Allium cepa L. American Journal of Botany, v.66, n.3, p.347-350.

[18] DEMASON, D. A. 1980. Localization of cell division activity in the primary thickening meristem in Allium cepa L. American Journal of Botany, v.67, n.3, p.393-399.

[19] DEMASON, D. A. 1983. The primary thickening meristem: definition and function in Monocotyledons. American Journal of Botany, v.70, n.6, p.955962.

[20] DEMASON, D. A., 1994. Stem thickening in monocotyledons. In: DENGLER, N. G.; IQBAL, M. Growth patterns in vascular plants. Dioscorides, Portland, Oreg. First citation in article. p. 288-310.

[21] DEMASON, D. A.; DIGGLE, P. K. 1984. The relationship between the primary thickening meristem and the secondary thickening meristem in Yucca 
whipplei Torr. III. Observations from histochemistry and autoradiography. American Journal of Botany, v.71, n.9, p.1260-1267.

[22] DEMASON, D. A.; WILSON, M. A. 1985. The continuity of primary and secondary growth in Cordyline terminalis (Agavaceae). Canadian Journal of Botany, v.63, n.11, p.1907-1913.

[23] DI LAURENZIO, L.; WYSOCKA-DILLER, J.; MALAMY, J. E.; PYSH, L.; HELARIUTTA, Y.; FRESHOUR, G.; HAHN, M. G.; FELDMANN, K. A.; BENFEY, P. N. 1996. The SCARECROW gene regulates an asymmetric cell division that is essential for generating the radial organization of the Arabidopsis root. Cell, v.86, n.3, p.423-433.

[24] DIGGLE, P. K.; DEMASON, D. A. 1983. The relationship between the primary thickening meristem and the secondary thickening meristem in Yucca whipplei Torr. I. Histology of the mature vegetative stem. . American Journal of Botany, v.70, n.8, p.1195-1204.

[25] DIGGLE, P. K.; DEMASON, D. A. 1983. The relationship between the primary thickening meristem and the secondary thickening meristem in Yucca whipplei Torr. II. Ontogenetic relationship within the vegetative stem. American Journal of Botany, v.70, n.8, p.1205-1216.

[26] ESAU, K., 1965. Plant anatomy 2ed: New York : Wiley. 767 p.

[27] EVANS, T. M.; FADEN, R. B.; SIMPSON, M. G.; SYTSMA, K. J. 2000. Phylogenetic Relationships in the Commelinaceae: I. A. Cladistic Analysis of Morphological Data. Systematic Botany, v.25, n.4, p.668-691.

[28] EVANS, T. M.; SYTSMA, K. J.; FADEN, R. B.; GIVNISH, T. J. 2003. Phylogenetic Relationships in the Commelinaceae: II. A Cladistic Analysis of rbcL Sequences and Morphology. Systematic Botany, v.28, n.2, p.270-292.

[29] FADEN, R. B., 1985. Commelinaceae. In: DAHLGREN, R. M. T.; CLIFFORD, H. T.; YEO, P. F. The families of the Monocotyledons. Berlin: Springer. p. 381-387.

[30] FADEN, R. B., 1998. Commelinaceae. In: KUBITZKI, K. The families and genera of vascular plants: Flowering plants - Monocotyledons: Springer. $p$. 109-129.

[31] FADEN, R. B. 1983. Phytogeography of African Commelinaceae. Bothalia, v.14, p.553-557. 
[32] FADEN, R. B.; HUNT, D. R. 1991. The Classification of the Commelinaceae. Taxon, v.40, n.1, p.19-31.

[33] FAHN, A., 1967. Plant Anatomy. 1 ed: Oxford; New York : Pergamon Press. 534 p.

[34] FUKAKI, H.; WYSOCKA-DILLER, J.; KATO, T.; FUJISAWA, H.; BENFEY, P. N.; TASAKA, M. 1998. Genetic evidence that the endodermis is essential for shoot gravitropism in Arabidopsis thaliana. The Plant Journal, v.14, n.4, p.425430.

[35] GIFFORD, E. M.; BAYER, D. E. 1995. Developmental anatomy of Cyperus esculentus (Yellow Nutsedge). International Journal of Plant Sciences, v.156, n.5, p.622-629.

[36] GUILLAUD, A. 1878. Rechersches sur l'anatomie comparée et le developpement des tissues de la tige dans les monocotylédones. Annals Sci Nat Bot Ser, v.6 n.5, p.1-176.

[37] HOLM, T. 1907. Rubiaceae: Anatomical Studies of North American Representatives of Cephalanthus, Oldenlandia, Houstonia, Mitchella, Diodia, and Galium. Botanical Gazette, v.43, n.3, p.153-186.

[38] JUDD, W. S.; CAMPBELL, C. S.; KELLOGG, E. A.; STEVENS, P. F.; DONOGHUE, M. J., 2002. Plant Systematics: A Phylogenetic Approach. Second Edition ed. Sunderland, Massachusettsp.

[39] KARRFALT, E. 1984. The Origin and Early Development of the RootProducing Meristem of Isoetes andicola L. D. Gomez. Botanical Gazette, v.145, n.3, p.372-377.

[40] KARRFALT, E. 1986. New observations on the structure and development of Nathorstianella. Review of Palaeobotany and Palynology, v.47, n.1-2, p.18.

[41] KRAUSS, B. H. 1948. Anatomy of the Vegetative Organs of the Pineapple, Ananas comosus (L.) Merr Merr. I. Introduction, Organography, the Stem, and the Lateral Branch or Axillary Buds. Botanical Gazette, v.110, n.2, p.159-217.

[42] LERSTEN, N. R. 1997. Occurrence of endodermis with a casparian strip in stem and leaf.(Interpreting Botanical Progress). The Botanical Review, v.63, n.3, p.265-268. 
[43] MACHADO, S. R.; OLIVEIRA, D. M. T.; DIP, M. R.; MENEZES, N. L. 2004. Morfoanatomia do sistema subterrâneo de Smallanthus sonchifolius (Poepp. \& Endl.) H. Robinson (Asteraceae). Revista Brasileira de Botânica, v.27, n.1, p.115-123.

[44] MANGIN, L. 1882. Origine et insertion des racines adventives et modifications corrélatives de la tîge chez les monocotylédones. Ann Sci Nat Bot, v.14, p.216-363.

[45] MELO-DE-PINNA, G. F. A.; MENEZES, N. L. 2003. Meristematic endodermis and secretory structures in adventitious roots of Richterago Kuntze (Mutisieae-Asteraceae). Revista Brasileira de Botânica, v.26, n.1, p.1-10.

[46] MENEZES, N. L. Estudos anatomicos e a taxonomia da familia Velloziaceae. 1970, 95 f. Tese de Doutorado, Universidade de São Paulo, São Paulo.

[47] MENEZES, N. L. 1971. Traqueídes de transfusão no gênero Vellozia Vand. Ciência e Cultura, v.23, p.389-409.

[48] MENEZES, N. L.; SILVA, D. C.; MELO-DE-PINNA, G. F. A., 2003. Folha. In: APPEZZATO-DE-GLÓRIA, B.; CARMELO-GUERREIRO, S. M. Anatomia Vegetal. Viçosa: UFV. p. 303-325.

[49] MENEZES, N. L. D.; SILVA, D. C.; ARRUDA, R. C. O.; MELO-DE-PINNA, G. F.; CARDOSO, V. A.; CASTRO, N. M.; SCATENA, V. L.; SCREMIN-DIAS, E. 2005. Meristematic activity of the Endodermis and the Pericycle in the primary thickening in monocotyledons: considerations on the "PTM". Anais da Academia Brasileira de Ciências, v.77, p.259-274.

[50] MORITA, M. T.; SAITO, C.; NAKANO, A.; TASAKA, M. 2007. Endodermalamyloplast less 1 is a novel allele of SHORT-ROOT. Advances in Space Research, v.39, n.7, p.1127-1133.

[51] MUELLER, R. J. 1991. Identification of Procambium in the Primary Root of Trifolium pratense (Fabaceae). American Journal of Botany, v.78, n.1, p.5362.

[52] PENCKOWSKI, L. H.; ROCHA, D. C., 2006. Guia ilustrado de Identificação e controle de espécies de trapoerabas. 1 ed. Castro, PR: Fundação ABC. 50 p. 
[53] PEREIRA, T. S. 1987. Commelinaceae: estudo do desenvolvimento pósseminal de algumas espécies. Acta Biologica Leopoldensia, v.9, n.1, p.49-80.

[54] PIZZOLATO, T. D. 2006. Procambial initiation for the vascular system in the shoot of Tradescantia zebrina (Commelinaceae). International Journal of Plant Sciences, v.167, n.1, p.59.

[55] RODRIGUES, A. C.; ESTELITA, M. E. M. 2002. Primary and secondary development of Cyperus giganteus Vahl rhizome (Cyperaceae). Revista Brasileira de Botânica, v.25, p.251-258.

[56] RUDALL, P. 1984. Taxonomic and Evolutionary Implications of Rhizome Structure and Secondary Thickening in Iridaceae. Botanical Gazette, v.145, n.4, p.524-534.

[57] RUDALL, P. 1989. Stem Thickening Growth in Bulbous iridaceae. Botanical Gazette, v.150, n.2, p.132-138.

[58] RUDALL, P. 1991. Lateral meristems and stem thickening growth in monocotyledons. Botanical Review, v.57, n.2, p.p150(14).

[59] SACK, F. D. 1987. The structure of the stem endodermis in etiolated pea seedlings. Canadian journal of botany. Journal canadien de botanique, v.65, n.7, p.1514-1519.

[60] SACK, F. D. 1991. Plant gravity sensing. International Review of Cytology, v.127, p.193-252.

[61] SAJO, M. J.; RUDALL, P. J. 1999. Systematic vegetative anatomy and ensiform leaf development inXyris(Xyridaceae). Botanical Journal of the Linnean Society, v.130, n.2, p.171-182.

[62] SCHACHT, H., 1852. Die Pflanzenzelle, der inner bau und das Leben der Gewächse Berlin $471 \mathrm{p}$.

[63] SCHERES, B.; BENFEY, P. N. 1999. Asymmetric cell division in plants. Annual Review of Plant Physiology and Plant Molecular Biology, v.50, p.505-537.

[64] SEAGO JR, J. L.; PETERSON, C. A.; ENSTONE, D. E. 1999. Cortical ontogeny in roots of the aquatic plant, Hydrocharis morsus-ranae L. Canadian Journal of Botany, v.77, n.1, p.113-121. 
[65] SKUTCH, A. F. 1932. Anatomy of the Axis of the Banana. Botanical Gazette, v.93, n.3, p.233-258.

[66] SOUZA, V. C.; LORENZI, H., 2005. Botânica Sistemática: Guia llustrado para identificação das famílias de Angiospermas da flora brasileira, baseado em APG II.

.1 ed. Nova Odessa: Instituto Plantarum p.

[67] STEVENSON, D. W. 1980. Radial Growth in the Cycadales. American Journal of Botany, v.67, n.4, p.465-475.

[68] STEVENSON, D. W.; FISHER, J. B. 1980. The Developmental Relationship between Primary and Secondary Thickening Growth in Cordyline (Agavaceae). Botanical Gazette, v.141, n.3, p.264-268.

[69] STEVENSON, D. W.; POPHAM, R. A. 1973. Ontogeny of the primary thickening meristem in seedlings of Bougainvillea spectabilis. American Journal of Botany, v.60, n.1, p.1-9.

[70] TAKEDA, H. 1913. A Theory of 'Transfusion-tissue'. Ann Bot, v.os-27, n.2, p.359-363.

[71] TOMLINSON, P. B. 1966. Anatomical data in the classification of commelinaceae Journal of the Linnean Society, v.59, p. 371-395.

[72] TOMLINSON, P. B., 1969. III - Commelinales-Zingiberales. In Anatomy of the Monocotyledons (C.R. Metcalfe, ed.). Oxford, : Clarendon Press 446 p.

[73] TOMLINSON, P. B.; ZIMMERMANN, M. H. 1969. Vascular anatomy of monocotyledons with secondary growth- an introduction. . Journal Arnold Arbor, v.50, n.159-179.

[74] TROLL, V. W., 1948. Allgemeine Botanik Ein Lehrbuch auf vergleichend-biologischer Grundlage Stuttgart Ferdinand Enke. 749 p.

[75] VAN FLEET, D. S. 1942. The development and distribution of the endodermis and an associated oxidase system in monocotyledonous plants. American Journal of Botany, v.29, n.1, p.1-15.

[76] VAN FLEET, D. S. 1950. The cell forms, and their common substance reactions, in the parenchyma-vascular boundary. Bulletin of the Torrey Botanical Club, v.77, n.5, p.340-353. 
[77] VAN FLEET, D. S. 1961. Histochemistry and function of the endodermis. The Botanical Review, v.27, n.2, p.165-220.

[78] VAN TIEGHEM, P. H., 1898. Éléments de Botanique. I Botanique Générale. 30 ed. Paris: Masson Et Cie.p.

[79] VAN TIEGHEM, P. H., 1898. Éléments de Botanique. I Botanique Généralex. 30 ed. Paris: Masson Et Cie. 440 p.

[80] VIEIRA, R. C.; GOMES, D. M. S.; SARAHYBA, L. S.; ARRUDA, R. C. O. 2002. Leaf anatomy of three herbaceous bamboo species. Brazilian Journal of Biology, v.62, p.907-922.

[81] WILLIAMS, B. C. 1947. The structure of the meristematic root tip and origin of the primary tissues in the roots of vascular plants. American Journal of Botany, v.34, n.9, p.455-462.

[82] WILLS, G. D.; HOAGLAND, R. E.; PAUL, R. N. 1980. Anatomy of yellow nutsedge (Cyperus esculentus). Weed Science, v.28, n.4, p.432-437.

[83] WU, X.; LIN, J.; LIN, Q.; WANG, J.; SCHREIBER, L. 2005. Casparian strips in needles are more solute permeable than endodermal transport barriers in roots of Pinus bungeana. Plant and Cell Physiology, v.46, n.11, p.1799-1808.

[84] YARROW, G. L.; POPHAM, R. A. 1981. The ontogeny of the primary thickening meristem of Atriplex hortensis L. (Chenopodiaceae). American Journal of Botany, v.68, n.8, p.1042-1049. 

Capítulo 1 



\section{ENDODERME COM ATIVIDADE MERISTEMÁTICA EM RAÍZES DE CINCO ESPÉCIES DE COMMELINACEAE.}

\section{Resumo}

Este trabalho tem por objetivo mostrar a atividade meristemática da endoderme em raízes de cinco espécies de Commelinaceae (Commelina erecta. Floscopa glabrata, Dichorisandra tyrsiflora, Tradescantia spathacea e T. zebrina). Nas cinco espécies foi observado que na raiz as iniciais endodérmicas sofrem diversas divisões periclinais e dão origem às camadas radiadas de células do córtex. Observou-se ainda, que o cessar dessas divisões nem sempre ocorre simultaneamente em todas as células iniciais, pois, quando ocorre a diferenciação, células que sofreram uma última divisão aparecem ao lado de células que não apresentaram essa divisão. A geração de células pela endoderme pode ser verificada através da observação das células subseqüentes à mesma. Estas células subseqüentes estão dispostas em fileiras radiadas, onde é possível observar que existe uma progressão do tamanho celular do menor (adjacente à endoderme) para o maior (mais distante da endoderme). Estas fileiras de células que são resultantes da endoderme foram denominadas de derivadas da endoderme meristemática (DEM).

\section{Abstract}

The aim of this work is to show the meristematic activity of the endodermis in roots of five species of Commelinaceae (Commelina erecta, Floscopa glabrata, Dichorisandra tyrsiflora, Tradescantia spathacea e T. zebrina). In all species was observed the initial endodermis suffered several periclinal divisions, originating the radiate layers of the cortex cells. In addition, these divisions does not stop simultaneously in all initial cells because, when differentiation occurs, cells that had a last division apears beside cells that have not divide yet. The generation of cells by the endodermis can be verified observing its subsequent cells. These subsequent cells are disposed as rows and in a radiate pattern where is possible to observe a progression in cell size, that is, the cells become greater as the distance from the endodermis increases. These rows of cells are derived from the endodermis and are called derivatives of the meristematic endodermis (DME). 


\section{Introdução}

Desde o século XIX até o momento, é sabido por diversos autores [6, 12, 22, 24-26, 32] que o córtex na raiz é originado do meristema fundamental e a camada mais interna do córtex é a endoderme [12,13,26]. A endoderme é reconhecida por muitos autores principalmente por seus diferentes estágios de diferenciação, os quais regulam importantes processos fisiológicos que ocorrem entre o córtex e o sistema vascular da raiz $[9,12,13,20,43]$.

Os estágios de diferenciação variam em relação ao desenvolvimento da raiz e o número de estágios reconhecidos varia de acordo com os autores. Para Lux e Luxová [20] ocorrem três estágios de diferenciação na endoderme, porém, para esses autores, estes estágios são específicos para cada espécie. No estágio I (primary endodermis), a endoderme apresenta estrias de Caspary, formando uma contínua rede ao redor do cilindro vascular que funciona como uma barreira, evitando o movimento apoplástico de solutos e prevenindo o influxo de íons do cilindro vascular para o córtex, fato também referido por Enstone et al [9] e Peterson et al [29]. O estágio II (secondary endodermis), Lux e Luxová [20] afirmam que neste estágio ocorre em regiões mais desenvolvidas; nesta porção a endoderme encontra-se impregnada de suberina, formando lamelas nas superfícies internas de suas paredes, geralmente incluindo a área ocupada pela estria de Caspary.

Por outro lado, diferentemente da estria de Caspary, a lamela de suberina não é formada em todas as células da endoderme, pois, algumas células próximas aos pólos de protoxilema não desenvolvem essa lamela, sendo chamadas de células de passagem. Quando há estrias de Caspary, as 
células de passagem são as únicas que mantêm as estrias após o espessamento das células endodérmicas. A lamela de suberina forma uma cobertura hidrofóbica no entorno das células (exceto nas regiões ocupadas por plasmodesmas), evitando a entrada de patógenos. No estágio III (tertiary endodermis), a celulose é depositada assimetricamente assegurando um maior suporte mecânico para raiz $[9,20]$.

Além de formar uma barreira fisiológica, a endoderme possui outra importantíssima função não percebida pelos autores de livros de texto: a formação de parte ou de todo córtex das raízes de diversas plantas. Embora desde o século XIX, muitos autores tenham apresentado figuras mostrando em seus trabalhos que o córtex das raízes é formado por células com disposição radiada, sem apresentar qualquer explicação [12, 13, 22, 24, 42, 44], somente nos últimos 50 anos é que essa disposição foi atribuída a uma atividade meristemática da endoderme [26, 45] ou de uma pró-endoderme [37-39, 43]. 0 primeiro autor a mencionar e explicar essa função foi Williams [45] em estudos com raízes. As raízes analisadas pelo autor compreendiam três grandes grupos: Angiospermas, Gimnospermas e Pteridófitas. Estes estudos revelaram que a disposição radiada das células do córtex é devida à atividade centrífuga da endoderme. De acordo com Williams [45], a endoderme, nas plantas vasculares comporta-se como um câmbio e é responsável pela origem dos tecidos primários do córtex (ou de parte do córtex) das raízes, originando células em disposição radiada. Baseado nos estudos de Hurst (1956 apud Van Fleet [43]), Van Fleet [43] sugere como sinonímia para endoderme com atividade cambial o termo pró-endoderme. 
Segundo Williams [45], a capacidade meristemática da endoderme foi verificada em regiões próximas ao meristema apical e nesta região a célula do meristema fundamental divide-se para formar a endoderme e outra célula filha; as células da futura endoderme, por ele denominada como "células cambiais" sofrem divisões periclinais dando origem às células do córtex. Posteriormente, outros autores se referem ao mesmo processo e diversas denominações foram atribuídas a esta camada de células conforme mostrado na tabela 2.

Tabela 2. Nomes atribuídos à endoderme ou às células que a formam.

\begin{tabular}{|c|c|c|}
\hline Autor & Nome atribuído & Espécies \\
\hline Williams [45] & Células cambiais & $\begin{array}{c}74 \text { espécies Monocotiledôneas; } \\
105 \text { espécies de Dicotiledôneas; } \\
11 \text { espécies de Pteridófitas e } 5 \text { espécies } \\
\text { de Gimnospermas. }\end{array}$ \\
\hline Van Fleet [43] & Proendoderme & Não mencionado \\
\hline Mueller [27] & Proendoderme & Trifolium pratense (Fabaceae). \\
\hline Seago Jr. et al [37] & Proendoderme & Hydrocharis morsus-ranae \\
\hline Seago e Sholey [39] & Proendoderme & Typha glauca e \\
\hline & & Typha angustifolia \\
\hline Seago et al [38] & Proendoderme & Pontederia cordata \\
\hline Di Laurenzio et al [7] & Inicial endodérmica & Arabidopsis thaliana \\
\hline Scheres et al [35] & Inicial endodérmica & Arabidopsis thaliana \\
\hline Melo-de-Pinna e Menezes [25] & Endoderme meristemática & Richterago sp (Mutisieae-Asteraceae). \\
\hline Menezes et al [26] & Inicial endodérmica & $\begin{array}{l}\text { Cyperus papyrus, Cephalostemon } \\
\text { riedelianus e Lagenocarpus rigidus. }\end{array}$ \\
\hline
\end{tabular}


Menezes et al [26] foram as primeiras a demonstrar que a atividade meristemática da endoderme está presente não apenas na raiz, mas também, no caule e na folha.

Melo-de-Pinna e Menezes [25], Menezes et al [26] e Alves e Menezes [1] optaram pelo termo "endoderme com atividade meristemática", utilizando a denominação de "inicial endodérmica" quando ela se encontra em fase de divisão. É importante salientar que essas autoras deram essa denominação, desconhecendo, totalmente na ocasião, os trabalhos de genética molecular [7, 14, 19, 28, 35] que usavam a mesma denominação.

Os estudos de pesquisadores da genética molecular do desenvolvimento atribuíram à endoderme da raiz o termo: inicial endodérmica ("endodermal initial") $[7,14,19,28,35]$. Este termo foi adotado devido à capacidade de divisão da endoderme, pela presença de dois genes que regulam este mecanismo, o gene SCARECROW (SCR) e o gene SHORT- ROOT (SHR) [5, $7,14,35]$. Além disso, estudos recentes [5] com genes homólogos $S H R$ e $S C R$ em arroz (Oryza sp.) sugerem que este mecanismo é evolutivamente conservado, dando uma plausível explicação do porque de todas as plantas apresentarem uma única camada na endoderme. 


\section{Objetivos}

Este trabalho tem por objetivo demonstrar não apenas a atividade meristemática da endoderme na raiz das espécies de Commelinaceae aqui estudadas, mas também, as modificações que as iniciais apresentam após pararem de se dividir. 


\section{Materiais e Métodos}

Estas amostras foram fixadas em FAA (formaldeído 37\%, ácido acético glacial, etanol 50\% 1:1 $18 \mathrm{v} / \mathrm{v}$ ) [16], ou em Karnovisky por 24 horas, seguindose de desidratação em série etílica até a deposição de material em etanol 50\%.

O estudo do sistema radicular foi realizado a partir de cortes histológicos longitudinais e transversais obtidos à mão, utilizando lâmina de barbear, e através de micrótomo rotativo.

Os cortes à mão foram corados com azul de astra e safranina ou ainda safrablau (Bukatsch 1972 apud Kraus e Arduim 17) e, posteriormente, montados em lâminas histológicas com glicerina líquida 50\%.

Para obtenção dos cortes em micrótomo rotativo, o material foi incluído em parafina segundo a metodologia descrita por Sass [34], Johansen [16] ou Kraus e Arduim [17] ou em historresina [17]. Para inclusão em parafina, o material foi previamente desidratado em série butanólica terciária [16, 34]. A inclusão por historresina seguiu o procedimento indicado pelo fabricante (Leica). Nos cortes seriados em parafina foram testadas as colorações azul de astra e safranina (Bukatsch 1972 apud Kraus \& Arduim [17]). A montagem das lâminas histológicas realizou-se com Bálsamo do Canadá. Os cortes em historresina foram corados com azul de toluidina. 


\section{Resultados}

Em regiões próximas do ápice da raiz de Commelina erecta (Fig. 1.1A e D) é possível perceber o córtex radiado, constituído por derivadas da endoderme com atividade meristemática. Na Fig. 1.1D observam-se as iniciais endodérmicas e que as células radiadas aumentam de tamanho à medida que se afastam da inicial. Nos tecidos já diferenciados (Fig. 1.1B-C e E- F) percebe-se uma epiderme unisseriada com paredes espessadas, assim como, as células do córtex externo (interno à hipoderme) e a endoderme com células espessadas com reforço em U. Todo o córtex interno e o intermediário se originam da endoderme.

Em Dichorisandra tyrsiflora se observa a epiderme e a hipoderme unisseriadas (Fig. 1.2A-C, E) e também o córtex ainda com características radiadas (Fig. 1.2C, EG) mesmo em regiões mais diferenciadas. A utilização de fluorescência destaca bem a endoderme e a hipoderme na Fig 1.2B, e a endoderme e a medula na Fig. 1.2H. Ao que tudo indica, (Fig. 1.3A-D), a protoderme e o meristema fundamental se originam da mesma inicial do centro quiescente da mesma espécie.

Em Floscopa glabrata também é possível ver a presença de córtex radiado originado da inicial endodérmica (Fig. 1.4A-F). O destaque (Fig 1.4D) mostra uma célula da endoderme que não sofreu a mesma divisão das duas células endodérmicas contíguas a ela. Na mesma espécie é possível ver a origem independente da protoderme e do meristema fundamental (Fig. 1.5A-C). Pode-se perceber que este seria o momento em que surgiu a inicial endodérmica (Fig. 1.5D).

A espécie Tradescantia spathacea também apresenta as derivadas da endoderme meristemática (Fig 1.6A-D), sendo que na Fig. 1.6D observa-se a endoderme já diferenciada, com reforço em $U$ e que também apresenta células que não sofreram uma última divisão, como as contíguas, antes de sofrer diferenciação 
(Fig. 1.6D). Esta espécie apresenta velame (Fig. 1.6A), melhor demonstrado nas Fig. 1.7A-G. Nesta espécie a protoderme se divide (Fig. 1.7A-D), originando duas a três camadas de células; o destaque da Fig. 1.7D mostra a protoderme e suas resultantes, melhor observadas nas Fig. 1.7E-G, indicadas pelas setas. Nas regiões mais maduras, a camada externa do velame sofre divisões anticlinais originando células menores que constituem o epivelame, que apresenta pêlos absorventes. É possível ver a textura semelhante entre as células do epivelame e as demais células do velame (Fig. 1.7E-G) e a coincidência entre as células de várias fileiras. $\mathrm{Na}$ espécie Tradescantia zebrina (Fig. 1.8A-G) observa-se, também, a atividade meristemática da endoderme, a epiderme, a hipoderme unisseriadas e o córtex externo com várias fileiras de células espessadas. É importante observar o desencontro entre as células da endoderme que passaram por mais uma divisão antes de sofrerem diferenciação (Fig. 1.8F, G). Em seções longitudinais do ápice radicular (Fig. 1.9A-D) é possível notar que, aparentemente, a protoderme e o meristema fundamental têm a mesma origem. Observa-se, também, a célula do meristema fundamental que dá origem à inicial endodérmica (Fig. 1.9B, D). 


\section{Discussão}

As espécies Commelina erecta, Dichorisandra tyrsiflora, Floscopa glabrata, Tradescantia spathacea e T. zebrina possuem raízes do tipo adventício, as quais são encontradas em todas as plantas vasculares podendo formar-se em diversos pontos e, ainda, podem ocorrer no nível dos nós em associação com gemas axilares [11], como ocorre nas espécies aqui estudadas. Em monocotilêdoneas, de acordo com Holttum [15] as raízes do tipo adventício surgem na região nodal de plantas que não apresentam espessamento secundário.

O meristema apical das espécies analisadas é protegido pela coifa, a qual é originada do caliptrôgenio. Acima da coifa, encontram-se as iniciais, organizadas em um meristema do tipo fechado, como ocorre em Zea mays [32], onde cada região é formada por um grupo diferente de iniciais, como se observa em D. tyrsiflora, $F$. glabrata e T. spathacea, embora em $T$. zebrina aparentemente o meristema fundamental e a protoderme tenham sido originadas das mesmas iniciais. No ápice radicular do tipo fechado ocorrem três grupos de células iniciais: um para o cilindro central, um para o córtex e outro para a coifa podendo a epiderme ter origem das iniciais do córtex ou da coifa [12] com o que concorda Esau [10]. Clowes [4], analisando o ápice radicular de diversas Angiospermas, demonstrou que em Tradescantia virginiana o ápice radicular é do tipo fechado. Ainda de acordo com este autor, o meristema do tipo fechado está altamente relacionado com a radiação das células do córtex. Outra característica importante do meristema apical do tipo fechado é que as células derivadas deste meristema convergem para um ponto comum [41].

A epiderme unisseriada encontrada nas espécies analisadas origina-se da protoderme e atua como tecido de revestimento. No entanto, em $T$. spathacea ocorre um velame. 
A presença de pêlos radiculares foi constatada somente em $D$. tyrsiflora e $T$. spathacea; a presença desses pêlos promove uma maior área de absorção para as raízes, facilitando a entrada de solutos [2]. Além da presença dos pêlos, o velame encontrado em $T$. spathacea, é formado a partir de divisões periclinais da epiderme e é encontrado em diversas Monocotiledôneas aéreas, como orquídeas, bromélias, aráceas epífitas e Monocotiledôneas terrestres (Amaryllidaceae, Iridaceae, Orchidaceae, Velloziaceae, etc; Menezes informação pessoal). $O$ velame oferece proteção e reduz a perda de água [2, 30]. De acordo com Segecin e Scatena [40] as raízes adventícias externas de Tillandsia crocata, T. gardneri, T. geminiflora, $T$. linearis, $T$. streptocarpa, $T$. stricta e $T$. recurvata apresentam velame que promove proteção mecânica e evita a transpiração excessiva, auxiliando a sobrevivência dessas plantas em ambientes extremos. É interessante verificar o que já foi descrito para outras famílias, como por exemplo, em Bromeliaceae [30] onde, após a formação das camadas de células do velame, a camada externa sofre divisões anticlinais, originando o epivelame.

Já na região cortical encontra-se a hipoderme que se origina a partir do meristema fundamental. Muitos autores adotam a terminologia exoderme, por ser a camada mais externa do córtex e por poder apresentar estrias de Caspary, ou ainda, possuir uma ou mais células em espessura. Para Enstone et al [9] e Ma et al [21], a exoderme é um tipo especial de hipoderme que possui estrias de Caspary. Neste trabalho foi adotada a palavra hipoderme, por ela ser a camada mais externa do córtex, na raiz, no caule e também, na camada mais externa do mesofilo da folha, independente da presença de estrias ou espessamentos. Nas espécies analisadas a hipoderme é do tipo uniforme e unisseriada; o mesmo tipo encontrado em espécie como Zea mays [18]. Abaixo da hipoderme, o córtex externo também possui sua origem diretamente do meristema fundamental. 
O que chama muito a atenção nas raízes de todas as espécies estudadas é a radiação das células do córtex interno, encontrado nas espécies analisadas, devida à capacidade meristemática da endoderme. Isto também foi observado por diversos outros autores ao longo dos anos, por exemplo, Williams [45] verificou que o córtex de diversas espécies era formado por uma camada com atividade cambial, adjacente ao pleroma, a qual mais tarde transformar-se-ia em endoderme. A fase meristemática da endoderme foi chamada por Hurst (1956 apud Van Fleet [43]) de "pró-endoderme". Com base no trabalho de Hurst, Van Fleet [43] utilizou a mesma denominação próendoderme, o que, para Menezes et al [26] representa uma inicial endodérmica.

O mesmo autor, Van Fleet [43], propôs em seu trabalho uma hipótese histoquímica sobre a divisão aritimética da endoderme. Em seu trabalho, foi proposto que a endoderme possuía capacidade meristemática devida à presença de fenóis livres, naftóis e antróis nas células. Ainda, segundo este autor a divisão ocorre da seguinte maneira: a pró-endoderme divide-se em duas células, célula A e célula B. A célula $B$, mais externa, torna-se uma célula madura do córtex. $A$ célula $A$, mais interna, permanece meristemática dando origem as outras células do córtex, conforme mostrado na representação esquemática da Fig.1.10.

Estas fileiras de células são resultantes da endoderme com atividade meristemática e foram denominadas de derivadas da endoderme meristemática (DEM) por Menezes et al [26] em raízes de Cyperus papyrus, Cephalostemum riedelianus e Lagenocarpus rigidus. O mesmo padrão foi observado por Melo-dePinna e Menezes [25] em raízes adventícias de Richterago Kuntze.

Chama-se a atenção para o fato de as iniciais endodérmicas pararem de se dividir simultaneamente, mas é comum encontrar em todo o cilindro de células endodérmicas diferenciadas células que não sofreram uma última divisão situam-se entre as que sofreram mais uma divisão. 
Acompanhando as células radiadas do córtex interno, em F. glabrata foi encontrado um aerênquima primeiramente parecendo meatos alargados. De acordo com Seago [36], este aerênquima é do tipo radial expansígeno (expansão do espaço intercelular, por divisão e alargamento de células, sem colapso ou morte celular). 0 mesmo tipo de aerênquima é encontrado em Commelinales, especificamente em Pontederiaceae nas espécies Pontederia cordata e Eichhornia crassipes [38]. Ainda de acordo com Seago [36], o aerênquima encontrado em $F$. glabrata em estágios mais desenvolvidos é do tipo tangencial lisígeno, do mesmo tipo que ocorre em espécies da família Cyperaceae [23]. A formação deste aerênquima se dá através do colapso celular o qual dará origem a uma lacuna. Fatores ambientais e o hábito anfíbio [31] de Floscopa glabrata, semelhante ao de Cyperus giganteus [33], podem ter promovido a formação de dois aerênquimas diferentes. Em julho de 2006 o córrego da Serra do Cipó onde a espécie foi coletada estava parcialmente seco e os indivíduos foram encontrados em solo úmido; em março de 2007 os mesmos indivíduos foram encontrados completamente imersos, sugerindo assim, uma explicação para a presença de diferentes aerênquimas. A presença do aerênquima é devida, principlamente, a pouca oferta de oxigênio em ambientes alagados [3].

A partir dos anos 90, estudos com marcadores moleculares vêm elucidando os mecanismos envolvidos na diferenciação da endoderme. Depois da descoberta dos genes SCARECROW (SCR) e SHORT-ROOT (SHR) foi proposta uma teoria para a formação das células do córtex na raiz. A participação destes dois genes é essencial para o que os autores [7, 35] chamaram de Inicial endodérmica sofra uma divisão anticlinal seguida de uma periclinal, dando origem à endoderme e a uma célula cortical [7]. Este mecanismo molecular foi descrito primeiramente para Arabdopsis thaliana, espécie que possui apenas uma camada de células do córtex. No entanto, a 
formação de um córtex com inúmeras camadas, como as observadas neste trabalho, foi descrito por Nakajima et al [28] e Dolan [8].

Segundo esses autores, a proteína SHORT-ROOT (SHR) que é sintetizada no estelo passa para as células adjacentes (endoderme), uma vez transportadas para endoderme (por mecanismo não conhecido) a proteína SHR se liga à proteína SCR formando um complexo ativo de transcrição, o qual fica retido na endoderme. Este complexo localizado no núcleo regula a produção de mais SCR, o que, por sua vez, captura mais proteína SHR $[5,7,8]$. Plantas que possuem menores quantidades do transcrito do gene SCARECROW, (proteína SCR) e uma constante produção de SHORT-ROOT (SHR), possuem SHR "livres"; esse excesso permite à proteína SHR passar através da endoderme. Esta expressão ectópica de SHR induz a formação de inúmeras camadas de endoderme $[8,28]$. Isto poderia explicar a geração das DEM, descrita por Menezes et al. [26]. Porém, o experimento exemplificado acima não é sob condições naturais.

Após a fase meristemática, as iniciais endodérmicas que constituem a camada mais interna do córtex, sofrem diferenciação apresentando ou estrias de Caspary ou ainda, espessamento que podem ser de diversas naturezas. Admite-se que o principal composto deste espessamento seja a suberina, como observado por Van Fleet [43], podendo ocorrer depósito de lignina e, ainda, de celulose. O depósito de suberina é conhecido como a fase secundária da endoderme. Vários estudiosos acreditam que a deposição de suberina na parede tangencial é uma forma de defesa contra patógenos [9]. 


\section{Referências}

[1] ALVES, V. G.; MENEZES, N. L. D. 2008. Endodermis with meristematic activity in roots of species of Scleria Berg. (Cyperaceae). Revista Brasileira de Botânica. no prelo.

[2] APPEZZATO-DA-GL, B.; HAYASHI, A. H., 2003. Raiz. In: APPEZZATO-DA-GL, B.; CARMELO-GUERREIRO, S. M. Anatomia Vegetal. Viçosa: Universidade Federal de Viçosa (UFV). p. 267-273.

[3] ARMSTRONG, W.; JUSTIN, S. H. F. W.; BECKETT, P. M.; LYTHE, S. 1991. Root adaptation to soil waterlogging. Aquatic Botany, v.39, n.1-2, p.57-73.

[4] CLOWES, F. A. L. 2000. Pattern in root meristem development in angiosperms. New Phytologist, v.146, n.1, p.83-94.

[5] CUI, H.; LEVESQUE, M. P.; VERNOUX, T.; JUNG, J. W.; PAQUETTE, A. J.; GALLAGHER, K. L.; WANG, J. Y.; BLILOU, I.; SCHERES, B.; BENFEY, P. N. 2007. An evolutionarily conserved mechanism delimiting SHR movement defines a single layer of endodermis in plants. Science, v.316, n.5823, p.421-425.

[6] CUTTER, E. G. 1978. Plant anatomy: cells and tissues. Part I.

[7] DI LAURENZIO, L.; WYSOCKA-DILLER, J.; MALAMY, J. E.; PYSH, L.; HELARIUTTA, Y.; FRESHOUR, G.; HAHN, M. G.; FELDMANN, K. A.; BENFEY, P. N. 1996. The SCARECROW gene regulates an asymmetric cell division that is essential for generating the radial organization of the Arabidopsis root. Cell, v.86, n.3, p.423433.

[8] DOLAN, L. 2007. PLANT SCIENCE: SCARECROWs at the Border. Science, v.316, n.5823, p.377-378.

[9] ENSTONE, D. E.; PETERSON, C. A.; MA, F. 2003. Root endodermis and exodermis: structure, function, and responses to the environment Journal Plant Growth Regulation

v.21, n.4, p.335-351.

[10] ESAU, K., 1959. Anatomía Vegetal. Barcelona: Omega S. A. 729 p.

[11] ESAU, K., 1974. Anatomia das plantas com sementes. São Paulo: Editora da Universidade de São Paulo. 293 p. 
[12] ESAU, K. 1977. Anatomy of Seed Plants. Wiley, New York, ed, v.2, p.550.

[13] FAHN, A., 1967. Plant Anatomy. 1 ed: Oxford; New York : Pergamon Press. 534 p.

[14] FUKAKI, H.; WYSOCKA-DILLER, J.; KATO, T.; FUJISAWA, H.; BENFEY, P. N.; TASAKA, M. 1998. Genetic evidence that the endodermis is essential for shoot gravitropism in Arabidopsis thaliana. The Plant Journal, v.14, n.4, p.425-430.

[15] HOLTTUM, R. E. 1955. Growth-habits of monocotyledons-variations on a theme. Phytomorphology, v.5, n.4, p.399-413.

[16] JOHANSEN, D. A., 1940. Plant microtechnique. New York: McGraw-Hill.p.

[17] KRAUSS, J. E.; ARDUIN, M., 1997 Manual Básico de Métodos em Anatomia Vegetal. Rio de Janeiro: EDUR (Ed. Universidade Rural). 198 p.

[18] KROEMER, K. 1903. Wurzelhaut, Hypodermis und Endodermis der Angiospermenwurzel. Bibliotheca Bot., v.59, p.1-151.

[19] LIM, J.; HELARIUTTA, Y.; SPECHT, C. D.; JUNG, J.; SIMS, L.; BRUCE, W. B.; DIEHN, S.; BENFEY, P. N. 2000. Molecular analysis of the SCARECROW gene in maize reveals a common basis for radial patterning in diverse meristems. The Plant Cell, v.12, n.8, p.1307-1318.

[20] LUX, A.; LUXOVÁ, M. 2003. Growth and Differentiation of Root Endodermis in Primula acaulis Jacq. Biologia Plantarum, v.47, n.1, p.91-97.

[21] MA, F.; PETERSON, C. A. 2003. Current insights into the development, structure, and chemistry of the endodermis and exodermis of roots. Canadian Journal of Botany, v.81.

[22] MANGIN, L. 1882. Origine et insertion des racines adventives et modifications corrélatives de la tîge chez les monocotylédones. Ann Sci Nat Bot, v.14, p.216-363.

[23] MANI, P. A. 1962. Air-space tissue in Cyperus. Science and Culture, v.28, p.3940.

[24] MAUSETH, J. D., 1988. Plant Anatomy. The Bejamin, Cummings Publishing Company Inc. $560 \mathrm{p}$. 
[25] MELO-DE-PINNA, G. F. A.; MENEZES, N. L. 2003. Meristematic endodermis and secretory structures in adventitious roots of Richterago Kuntze (MutisieaeAsteraceae). Revista Brasileira de Botânica, v.26, n.1, p.1-10.

[26] MENEZES, N. L. D.; SILVA, D. C.; ARRUDA, R. C. O.; MELO-DE-PINNA, G. F.; CARDOSO, V. A.; CASTRO, N. M.; SCATENA, V. L.; SCREMIN-DIAS, E. 2005. Meristematic activity of the Endodermis and the Pericycle in the primary thickening in monocotyledons: considerations on the "PTM". Anais da Academia Brasileira de Ciências, v.77, p.259-274.

[27] MUELLER, R. J. 1991. Identification of Procambium in the Primary Root of Trifolium pratense (Fabaceae). American Journal of Botany, v.78, n.1, p.53-62.

[28] NAKAJIMA, K.; SENA, G.; NAWY, T.; BENFEY, P. N. 2001. Intercellular movement of the putative transcription factor SHR in root patterning. Nature, v.413, n.6853, p.307-311.

[29] PETERSON, C. A.; MURRMANN, M.; STEUDLE, E. 1993. Location of the major barriers to water and ion movement in young roots of Zea mays L. Planta, v.190, n.1, p.127-136.

[30] PITA, P. B.; MENEZES, N. L. 2002. Anatomia da raiz de espécies de Dyckia Schult. f. e Encholirium Mart. ex Schult. \& Schult. f.(Bromeliaceae, Pitcairnioideae) da Serra do Cipó (Minas Gerais, Brasil), com especial referência ao velame. Revista Brasileira de Botânica, v.25, n.1, p.25-34.

[31] POTT, V. J.; POTT, A., 2000. Plantas aquaticas do Pantanal. Brasília: Embrapa. 865 p.

[32] RAVEN, P. H.; EVERT, R. F.; EICHHORN, S. E., 2001. Raiz: estrutura e desenvolvimento. In:

Koogan. cap.25. p. 567-586.

[33] RODRIGUES, A. C. Desenvolvimento anatômico de sistema subterrâneo e do tecido Kranz das brácteas, e implicações ecológicas do rizoma de Cyperus giganteus Vahl (Cyperaceae) proviniente do Pantanal mato-grossence. 1999, 108 f, Universidade de São Paulo, São Paulo.

[34] SASS, J. E., 1951. Botanical Microtechnique lowa State College Press. 228 p.

[35] SCHERES, B.; BENFEY, P. N. 1999. Asymmetric cell division in plants. Annual Review of Plant Physiology and Plant Molecular Biology, v.50, p.505-537. 
[36] SEAGO, J. L. J.; MARSH, L. C.; STEVENS, K. J.; SOUKUP, A.; VOTRUBOVA, O.; ENSTONE, D. E. 2005. A Re-examination of the Root Cortex in Wetland Flowering Plants With Respect to Aerenchyma. Ann Bot, v.96, n.4, p.565-579.

[37] SEAGO JR, J. L.; PETERSON, C. A.; ENSTONE, D. E. 1999. Cortical ontogeny in roots of the aquatic plant, Hydrocharis morsus-ranae L. Canadian Journal of Botany, v.77, n.1, p.113-121.

[38] SEAGO JR, J. L.; PETERSON, C. A.; ENSTONE, D. E. 2000. Cortical development in roots of the aquatic plant Pontederia cordata (Pontederiaceae). American Journal of Botany, v.87, n.8, p.1116-1127.

[39] SEAGO JR, J. L.; PETERSON, C. A.; ENSTONE, D. E.; SCHOLEY, C. A. 1999. Development of the endodermis and hypodermis of Typha glauca Godr. and Typha angustifolia L. roots. Canadian Journal of Botany, v.77, n.1, p.122-134.

[40] SEGECIN, S.; SCATENA, V. L. 2004. Morfoanatomia de rizomas e raízes de Tillandsia L. (Bromeliaceae) dos Campos Gerais, PR, Brasil. Acta Botanica Brasilica, v.18, p.253-260.

[41] TORREY, J. G.; FELDMAN, L. J. 1977. The Organization and Function of the Root Apex. American Scientist, v.65, n.3, p.334-344.

[42] TROLL, V. W., 1948. Allgemeine Botanik Ein Lehrbuch auf vergleichendbiologischer Grundlage Stuttgart Ferdinand Enke. 749 p.

[43] VAN FLEET, D. S. 1961. Histochemistry and function of the endodermis. The Botanical Review, v.27, n.2, p.165-220.

[44] VAN TIEGHEM, P. H., 1898. Éléments de Botanique. I Botanique Généralex. 30 ed. Paris: Masson Et Cie. 440 p.

[45] WILLIAMS, B. C. 1947. The structure of the meristematic root tip and origin of the primary tissues in the roots of vascular plants. American Journal of Botany, v.34, n.9, p.455-462. 

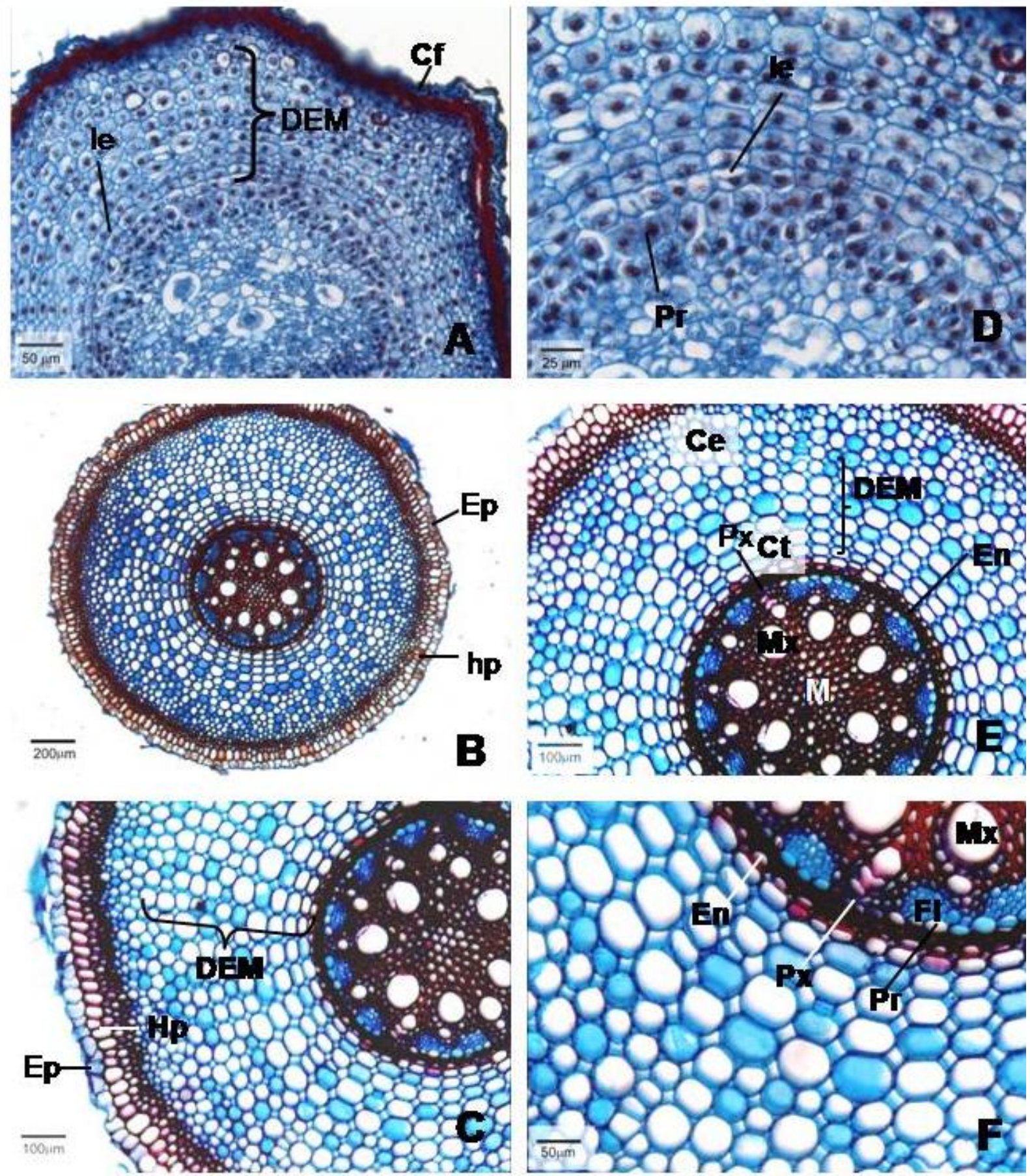

Fig. 1.1A-F - Seções transversais da raiz de Commelina erecta. As Fig 1.1A e D mostram a região próxima ao ápice envolvida pela coifa (Cf) com o córtex (Ct) radiado, as derivadas da endoderme meristemática (DEM) e as iniciais endodérmicas (le). Fig. 1.1B-C e E-F: região onde os tecidos primários estão completamente diferenciados, notando-se ainda uma epiderme (Ep) unisseriada e a hipoderme (Hp) unisseriada; abaixo dela 3 a 4 camadas de células corticais com paredes espessadas e o restante do córtex (Ct) com paredes primárias e a radiação de células bem marcadas, especialmente nas primeiras camadas do córtex interno. Ce- Córtex externo; En- Endoderme; FIFloema; Mx- Metaxilema; Pr- Periciclo; Px- Protoxilema. 

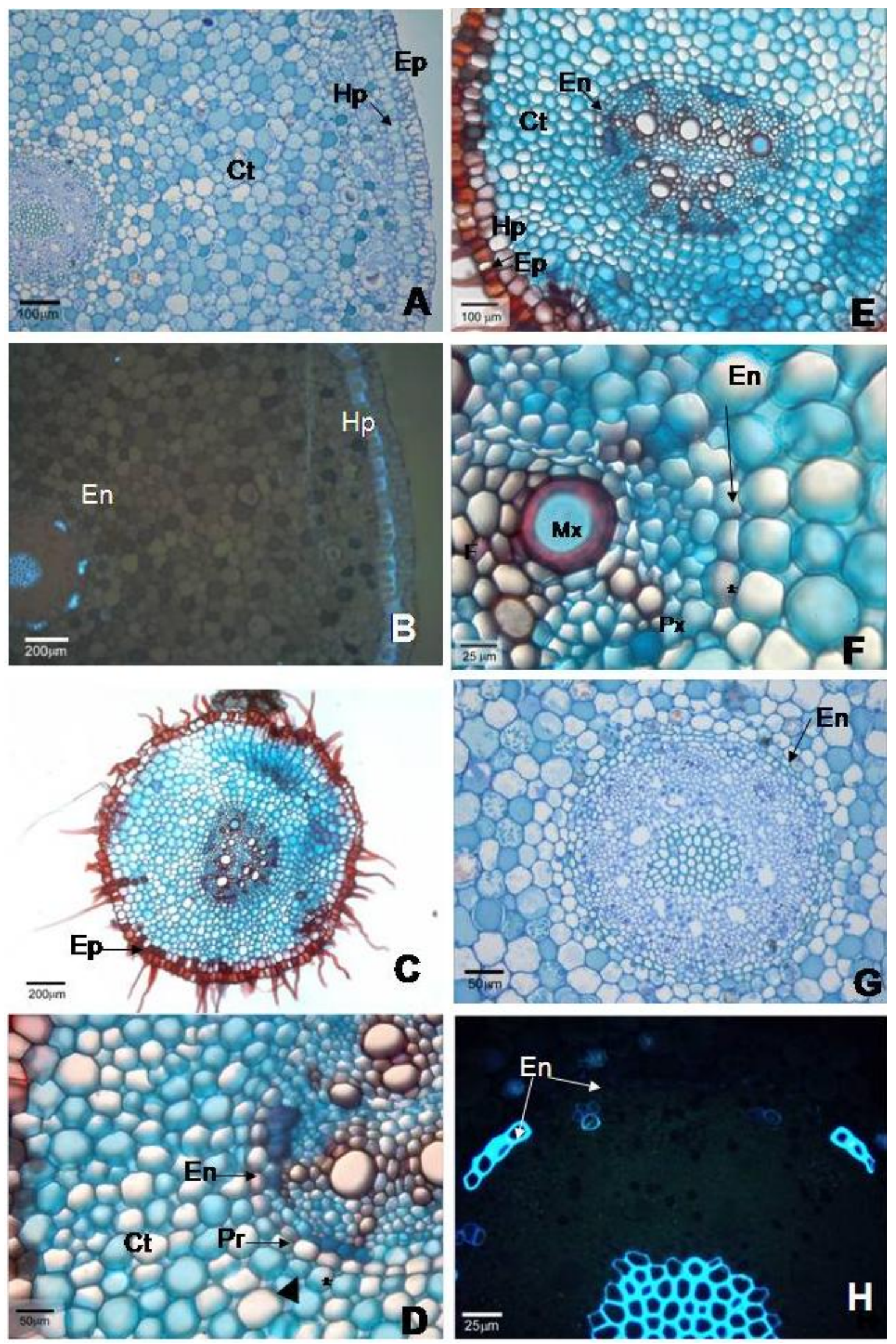

Fig. 1.2A-H - Seções transversais da raiz de Dichorisandra tyrsiflora notando-se nas Fig. 1.2B e H em destaque, células da hipoderme $(\mathrm{Hp})$ e da endoderme $(\mathrm{En})$ e na Fig. $1.2 \mathrm{H}$ pela reação hemisulfato de Berberina exposta à fluorescência. Ct- Córtex; Ep- Epiderme; Fl- Floema; Mx- Metaxilema; PrPericiclo; Px- Protoxilema. 

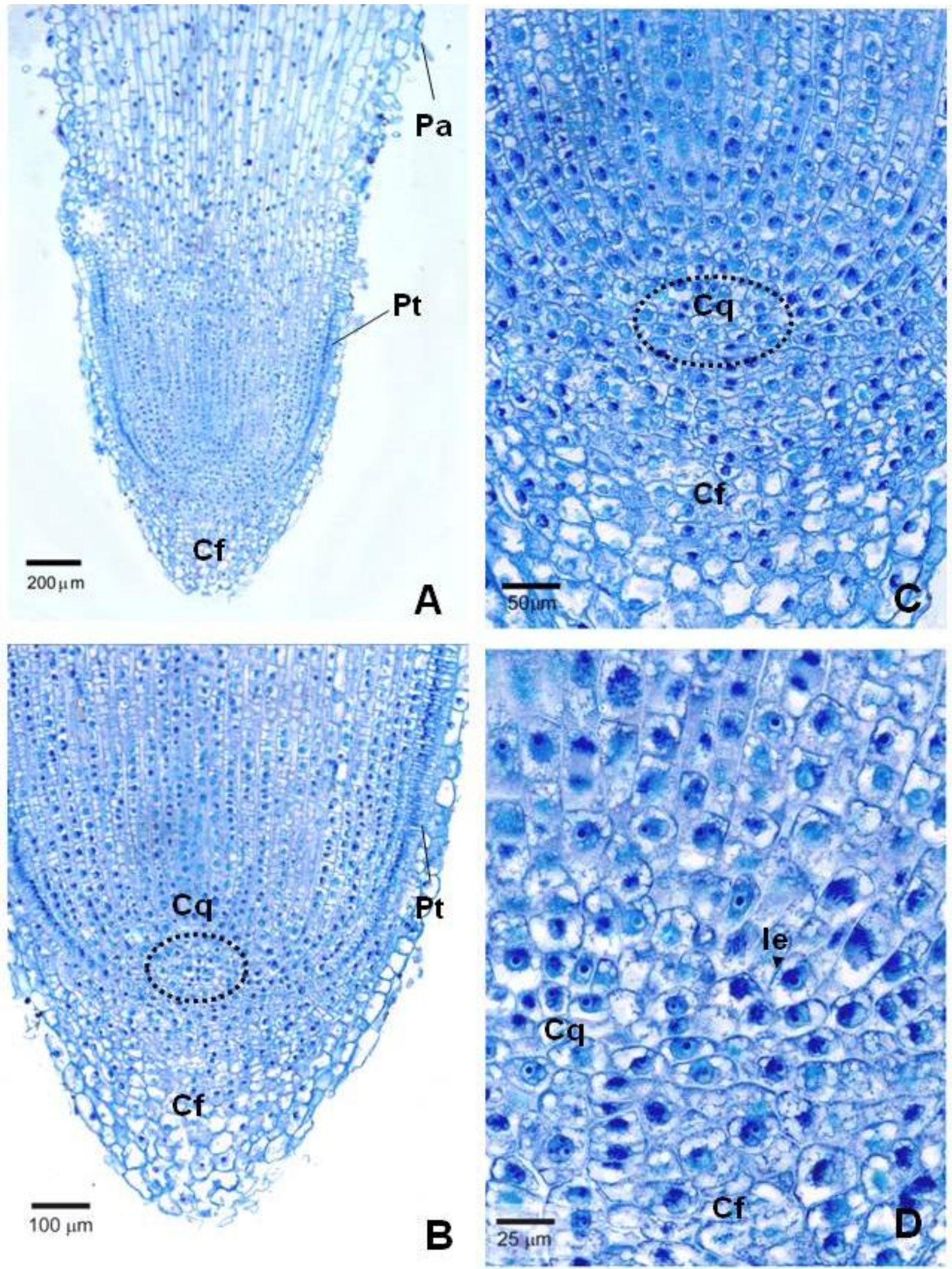

Fig. 1.3A-D - Seções longitudinais de raiz de Dichorisandra tyrsiflora destacando-se o centro quiescente (Cq) nas Fig. 1.3B e C. Cf- Coifa; Pa- Pêlo absorvente; Pt- Protoderme. 

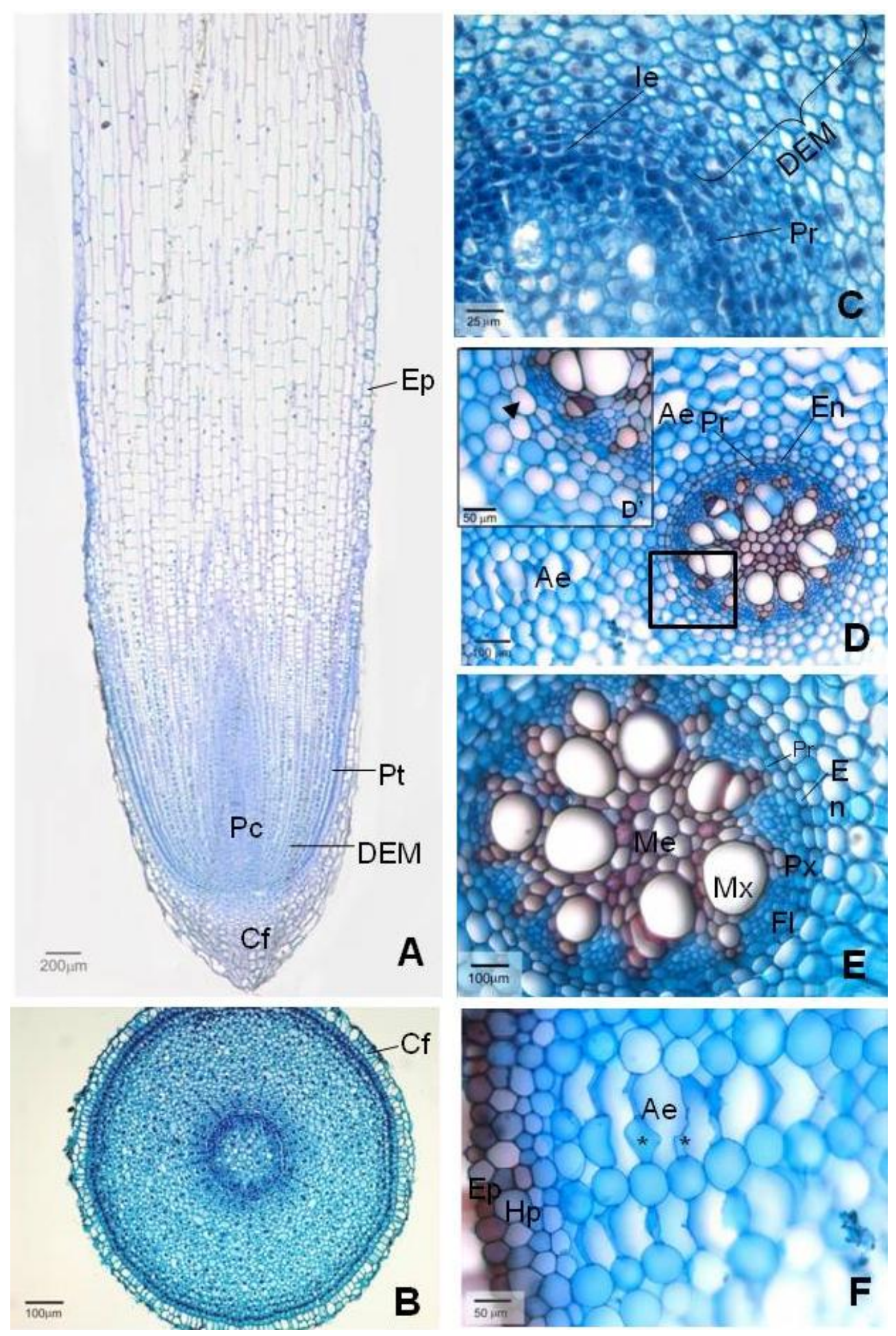

Fig. 1.4A-F - Seções longitudinal (Fig. 1.4A) e transversais (Fig. 1.4B-F) da raiz de Floscopa glabrata. Fig.1.4A seção longitudinal do ápice no qual se verificam a protoderme $(\mathrm{Pt})$, a região correspondente a derivadas da endoderme meristemática (DEM) da Fig.1.4C, o procâmbio (PC) e a coifa (Cf). Fig. 1.4B: aspecto geral de uma seção transversal região da raiz envolvida pela coifa. Fig. 1.4C: ampliação da Fig. 1.4A: notando-se o córtex radiado com inicial endodérmica (le) e as derivadas da endoderme meristemática (DEM), observando-se espaços entre as células mais distantes das iniciais endodérmicas. Fig. 1.4D, 1.4D', 1.4E e 1.4F: regiões com tecidos primários diferenciados, observando-se no detalhe da Fig. 1.4D' a célula inicial endodérmica não dividida (cabeça de seta) entre células iniciais recémdivididas. Fig. 1.4F, observa-se no córtex um aerênquima (Ae). En- Endoderme; Ep- Epiderme; FIFloema; Hp- hipoderme Me- medula; Mx- Metaxilema; Pr- Periciclo; Px- Protoxilema. 

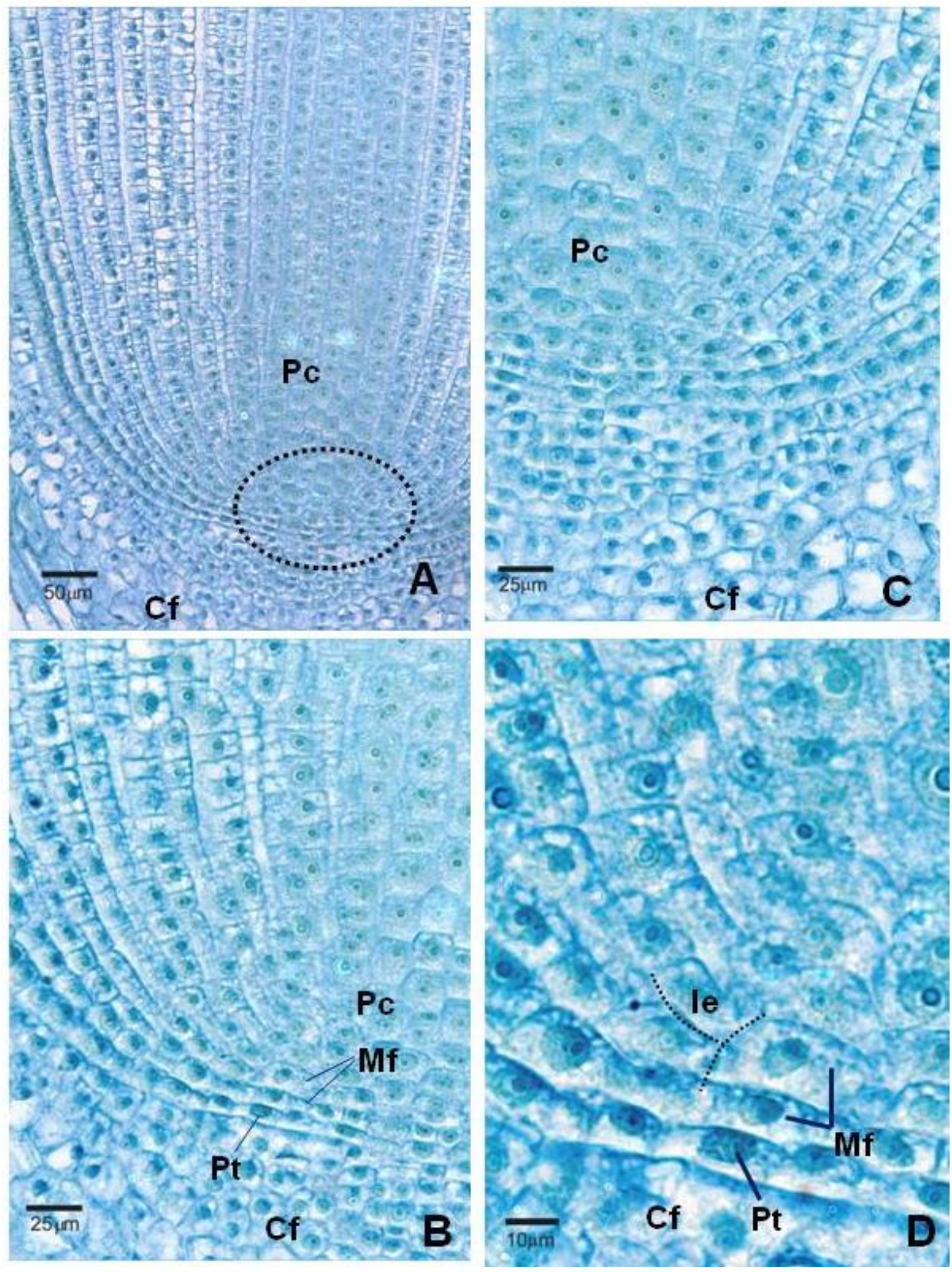

Fig. 1.5A-D - Seções longitudinais da raiz de Floscopa glabrata destacando o centro de quiecência (Fig. 1.5A), a protoderme (Pt), o meristema fundamental (Mf) nas Fig. 1.5B e D e a inicial endodérmica (le) na Fig. 1.5D. Cf- Coifa; Pc- Procâmbio. 

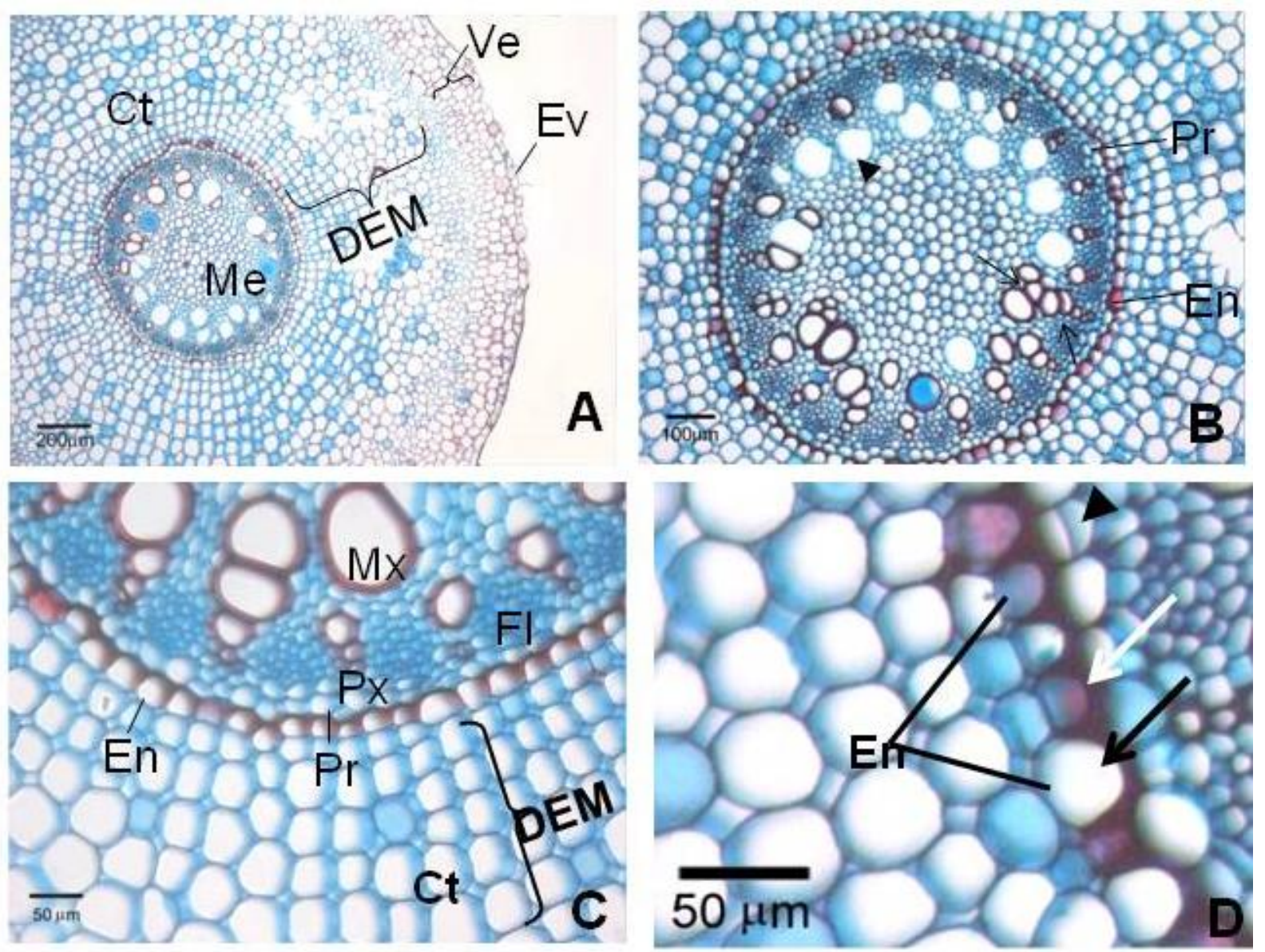

Fig. 1.6A-G - Seções transversais (1.6A-D) da raiz de Tradescantia spathacea. Fig 1.6A, onde se observam as DEM (Derivadas da endoderme meristemática). Observa-se o córtex (Ct) radiado constituído pelas derivadas da endoderme meristemática (Fig. 1.6A-C), a endoderme (En) com reforço em U, os tecidos vasculares diferenciados (Fig. 1.6B) e o metaxilema (Mx) em diferenciação (Fig 1.6B, cabeça de seta). Fig. 1.6D, observa-se uma célula endodérmica não dividida (seta preta) ao lado de células que sofreram mais uma divisão (seta branca). A cabeça de seta da Fig. 1.6D indica célula pericíclica em divisão. MeMedula; Pr- Periciclo; Px- Protoxilema. 

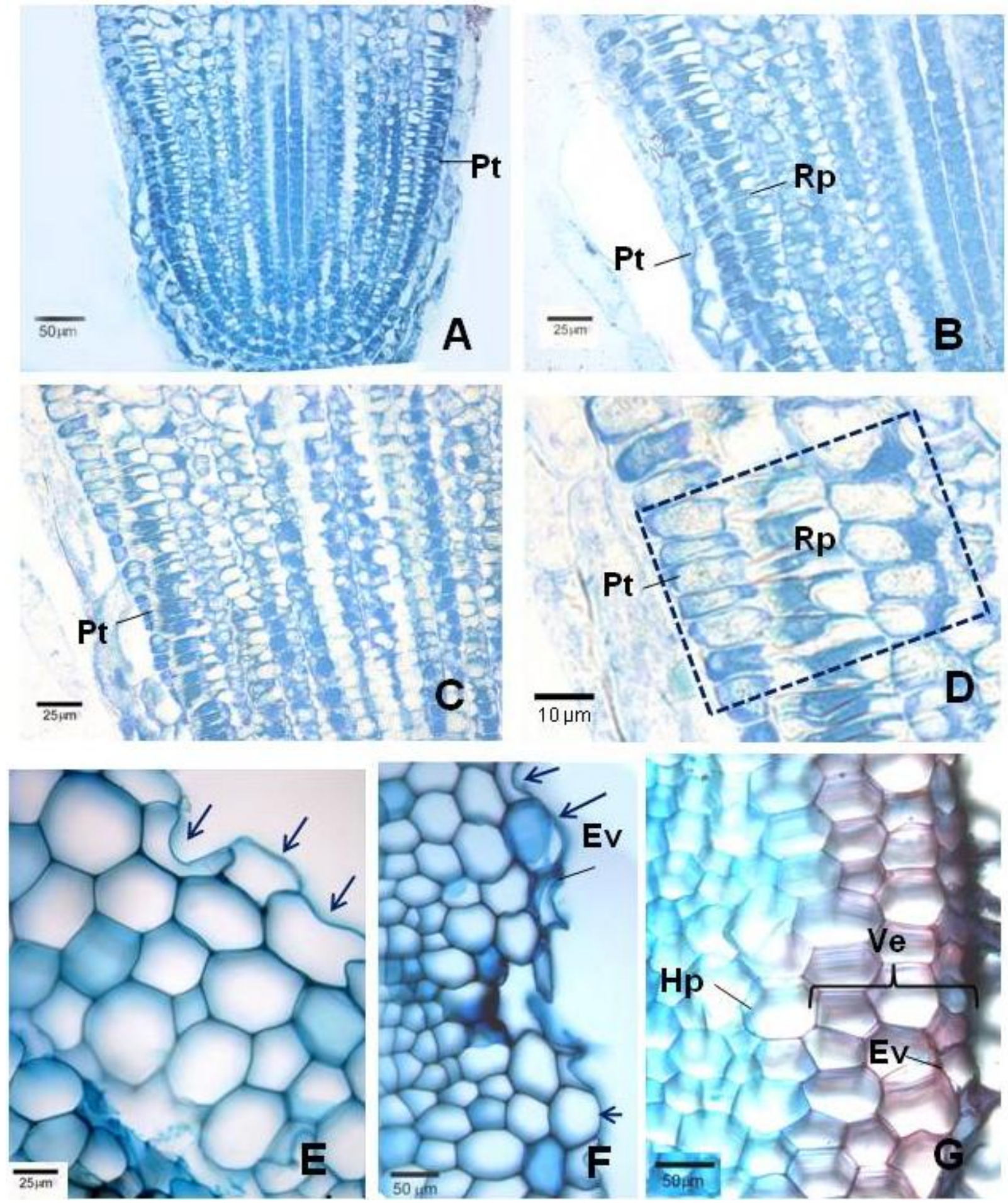

Fig. 1.7A-G - Seções longitudinais (1.7A-D) e transversais (1.7E-G) da raiz de Tradescantia spathacea nas quais se observam as células da protoderme $(\mathrm{Pt})$ e as suas resultantes $(\mathrm{Rp})$ originando o velame $(\mathrm{Ve})(\mathrm{Fig}$. $1.7 \mathrm{~A}-\mathrm{D})$, observado nas Fig. 1.7E-G. As setas indicam as fileiras resultantes da mesma célula protodérmica. A textura das células do epivelame (Ev) apresentam as paredes das células com a mesma textura Fig. 1.7E-G. 

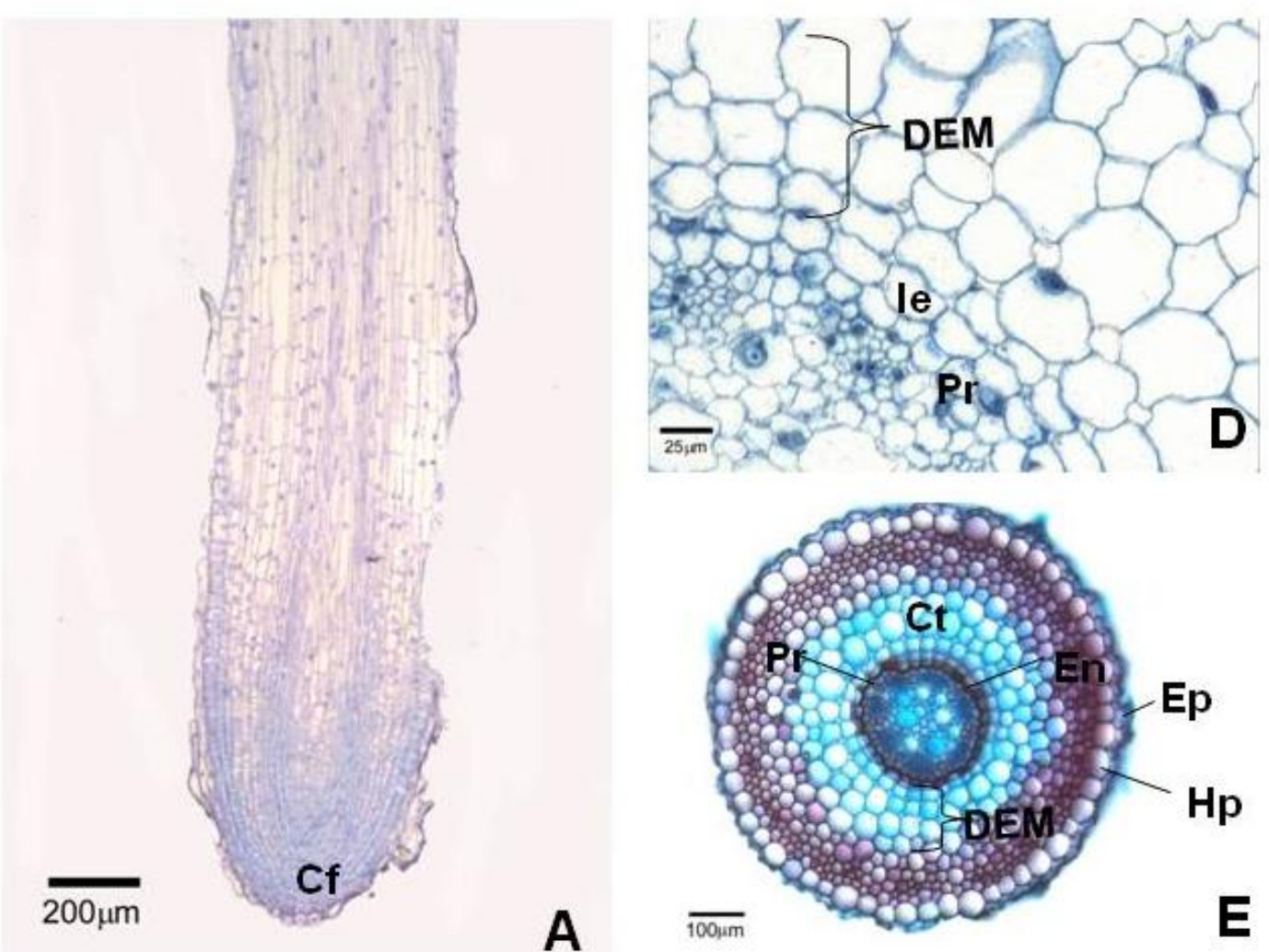

A
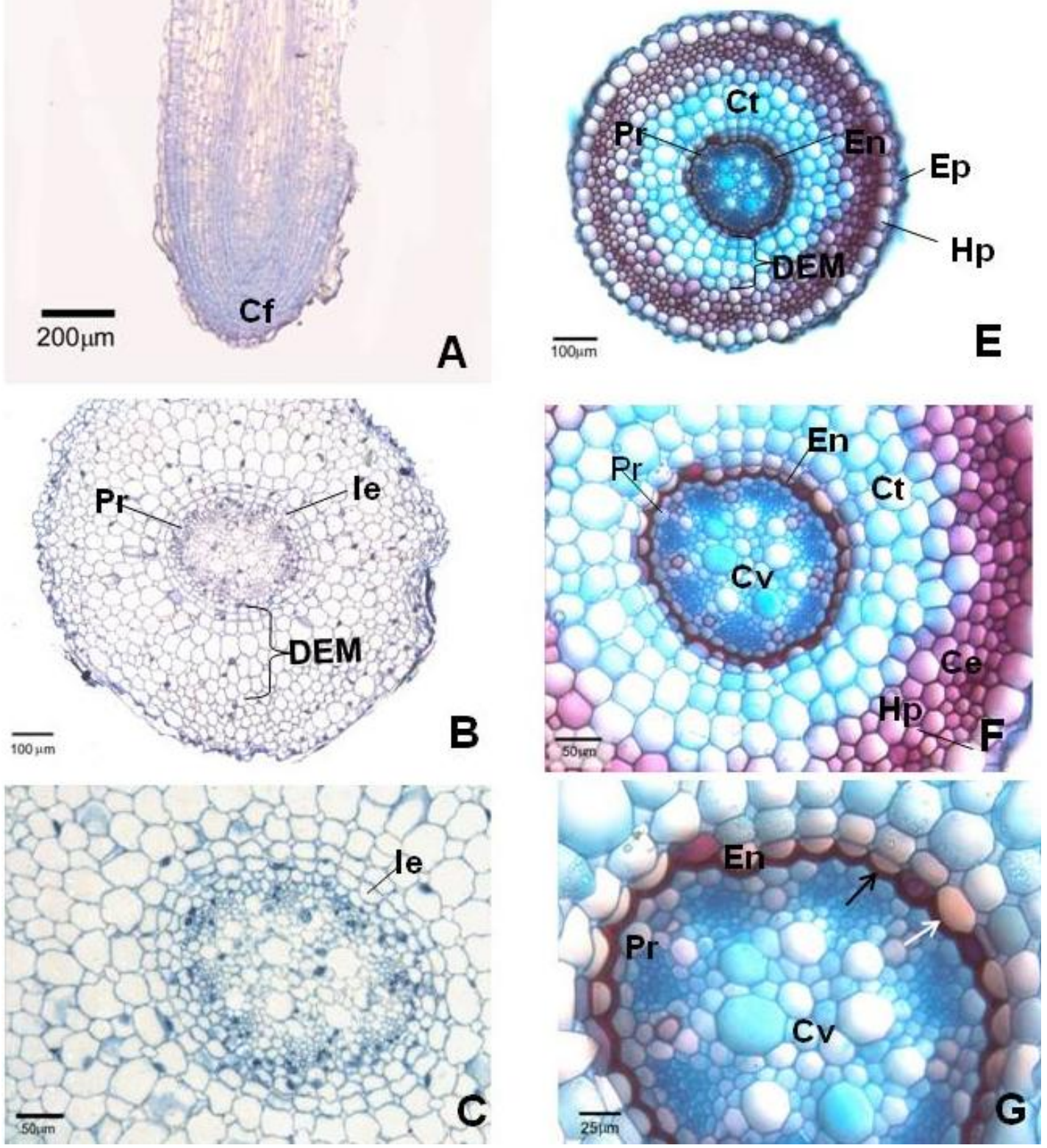

Fig. 1.8A-G - Seções longitudinal (Fig. 1.8A) e transversais (Fig. 1.8B-G) da raiz de Tradescantia zebrina. Fig 1.8A-D: tecidos imaturos e Fig. 1.8E-G com tecidos diferenciados; chama-se atenção para o córtex externo $(\mathrm{Ce})$ que nesta raiz apresenta-se com as paredes espessadas e também para as células da endoderme (En) que sofreram uma divisão a mais (Fig. 3G seta preta) do que a indicada pela seta branca. Cf- Coifa; Ct- Córtex; Cv- Cilindro vascular; DEM- Derivadas da Endoderme Meristemática; Ep- Epiderme; le - Inicial endodérmica; Hp- Hipoderme; Pr- Periciclo. 

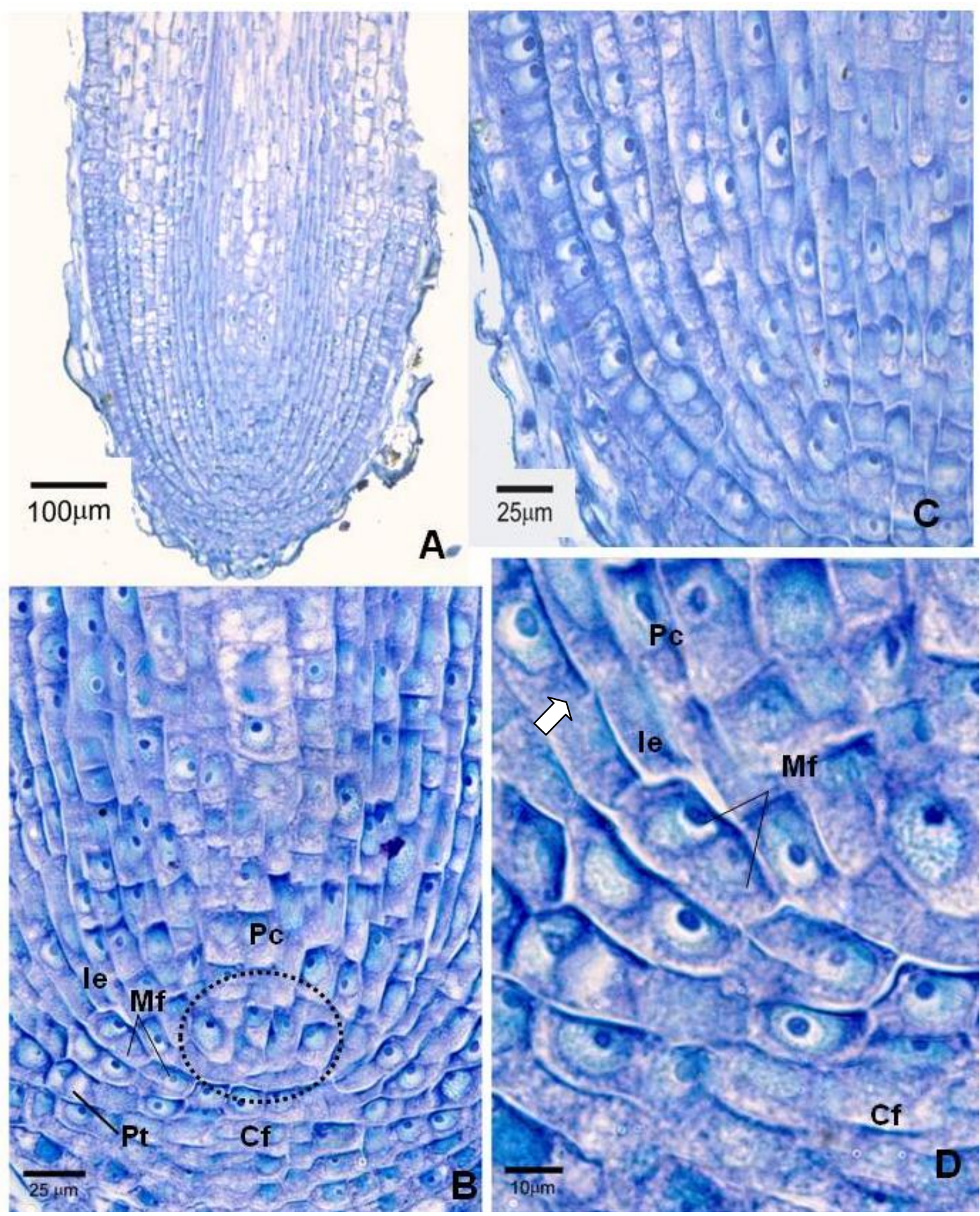

Fig. 1.9A-D - Seções longitudinais da raiz de Tradescantia zebrina notando-se o centro quiescente em destaque na Fig. 1.9B e na Fig. 1.9D, célula do meristema fundamental (Mf) que originou a inicial endodérmica (le) e outra do meristema (seta). Cf- Coifa; Pc- Procâmbio. 



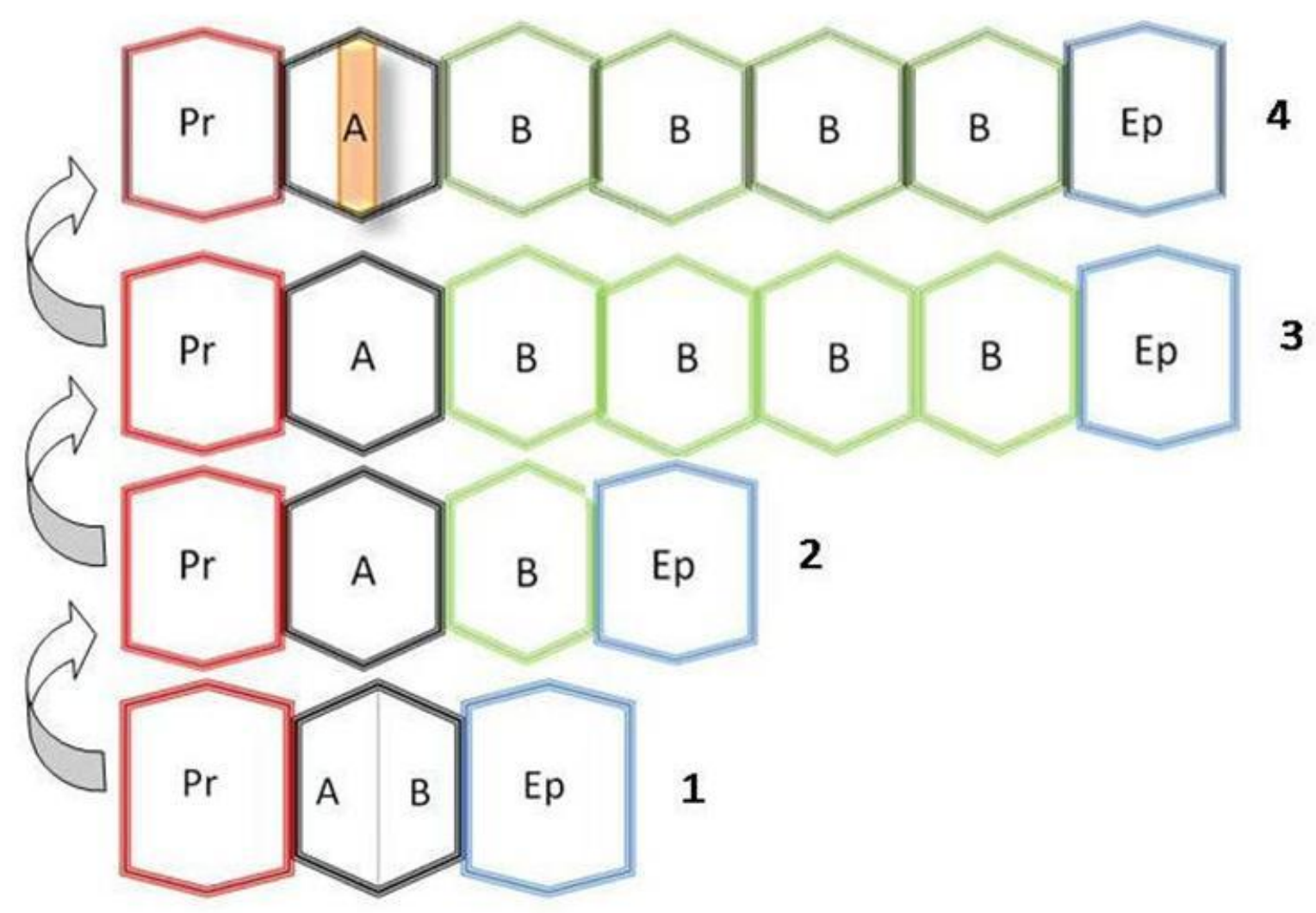

Fig. 1.10 - Esquema representando a fase de divisão da endoderme. Em 1, (região próxima ao ápice da raiz) a célula ( $\mathbf{A} / \mathbf{B})$ pró-endoderme está se dividindo, notando-se o periciclo $(\mathbf{P r})$ e a epiderme (Ep). Em 2, a divisão da pró-endoderme deu origem a duas células filhas: a célula (A), que representa a célula filha que permanecerá em divisão; a célula (B), célula filha que se torna madura (derivada), formando o córtex da raiz. Em 3 o córtex já está formado e a endoderme perde a capacidade de divisão iniciando o processo de diferenciação. Em 4 a endoderme apresenta-se com estrias de Caspary. 
Capítulo 2 


\section{SISTEMA CAULINAR EM ESPÉCIES DE COMMELINACEAE}

\section{Resumo}

No caule, a atividade meristemática do periciclo e da endoderme é limitada à região nodal. Nesta região ocorre a formação de novas raízes, gemas caulinares e saídas de traços. Nos entrenós, os feixes vasculares são colaterais e a endoderme se apresenta, em geral, como bainha amilífera, podendo apresentar estrias de Caspary; o periciclo encontra-se parenquimático. Na região do nó, observa-se uma intensa atividade do periciclo (ou da região pericíclica) formando feixes vasculares colaterais envoltos por fibras e o plexo periférico em direção às raízes adventícias. Verificou-se também uma pequena atividade da endoderme, produzindo duas a três camadas do córtex interno. No primeiro e no segundo entrenós, a endoderme apresenta-se suberificada e o periciclo parenquimático. Corroborando com estudos recentes e autores do século XIX, o espessamento primário é devido à atividade centrípeta do periciclo e à atividade centrífuga da endoderme.

\section{Abstract}

In the stem, the meristematic activity of pericycle and endodermis is limited to the nodal region. In this region occurs the formation of new adventitious roots, buds and leaf traces. In the internodes the vascular bundles are collateral, the endodermis usually appears as a starch sheath, which may have Caspary strips, and the pericycle is parenchymatous. In the nodal region, there is intensive activity of pericycle (or pericycle region), promoting the formation of vascular bundles with fibers around it, and the peripheral plexus of adventitious roots. Moreover, there was also little activity of endodermis producing only from two to three layers of inner cortex. The endodermis has suberin. In conclusion, the primary thickening is caused by the centripetal activity of pericycle and the centrifugal activity of the endodermis. 


\section{Introdução}

A família Commelinaceae é constituída principalmente de ervas perenes, comumente rizomatosas e suculentas [52].

O caule, de acordo com alguns autores [46,52], foi descrito há mais de um século como aquele que difere na organização de seu sistema vascular em relação a todas as outras Monocotiledôneas. Tomlinson [52] declara que a natureza deste grupo é enfatizada por sua construção uniforme e pelo número de aspectos anatômicos comuns a todos os membros. Segundo o mesmo autor, o caule, por sua vez, exibe um córtex estreito sem vascularização, um cilindro central envolvido por uma camada por ele denominada endodermóide e, freqüentemente, por esclerênquima. Há ainda, um sistema longitudinal de feixes vasculares os quais se conectam apenas na região nodal, formando um plexo nodal $[46,52]$

Os processos de crescimento primário do caule foram estudados por Scott e Priestley [46] em Tradescantia flumensis. Nesta espécie os autores reconheceram a endoderme no caule em seu estágio de bainha amilífera; na região nodal, observaram a formação de raízes adventícias no limite entre o córtex e o cilindro central. Apesar dos estudos descritos acima estarem relacionados com a construção primária do caule, a qual é originada pelos meristemas apicais (procâmbio, meristema fundamental e protoderme), a produção de novos tecidos e a manutenção destes não foi mencionada na literatura para esta família.

Segundo Rudall [44], após o estabelecimento dos tecidos primários, a manutenção do corpo primário vegetativo de muitas Monocotiledôneas que 
apresentam rizomas, cormos e bulbos (e possivelmente, em todas Monocotiledôneas) é, para muitos autores, realizado pelo Meristema de Espessamento Primário (MEP - do inglês "Primary Thickening Meristem" PTM). A autora descreve que este tecido é encontrado na região pericíclica de todas as Monocotiledôneas e ainda, é responsável pela formação de raízes adventícias e pela formação de ligações da vascularização entre raiz e caule e caule e folha.

Embora Rudall [44], após sua revisão sobre o tema, admita que o MEP possa ocorrer em todas as Monocotiledôneas, para DeMason [10] o meristema de espessamento primário ocorre em Monocotiledôneas que apresentam um sistema caulinar compacto e espesso como em cormos e bulbos, por exemplo.

Pizzolato [36] descreve que o plexo nodal externo encontrado em Commelinacea é derivado do meristema de espessamento primário e este depois de cessar sua atividade torna-se uma zona intermediária ou a endoderme, descrito como um anel que envolve os feixes periféricos por Scott e Priestley [46].

Recentemente, Menezes e colaboradores [1, 2, 33] demonstraram que o espessamento primário nas monocotiledôneas é realizado pela endoderme (atividade centrífuga) e pelo periciclo (atividade centrípeta) ambos em atividade meristemática. 


\section{Objetivos}

O objetivo deste trabalho é mostrar a presença dos tecidos endoderme e periciclo no caule de Commelinaceae, bem como as suas capacidades meristemáticas. 


\section{Materiais e métodos}

Primeiramente foi realizada uma análise morfológica prévia da planta em campo. Posteriormente foram selecionados e fixados fragmentos de cada região do caule para análise anatômica.

Estas amostras em diferentes fases de desenvolvimento foram fixadas em FAA (formaldeído 37\%, ácido acético glacial, etanol 50\% 1:1:18 v/v) [24], ou em Karnovisky por 24 horas, seguindo-se de desidratação em série etílica até a deposição de material em etanol $50 \%$.

O estudo do sistema caulinar foi realizado a partir de cortes histológicos longitudinais e transversais obtidos à mão, utilizando, lâmina de barbear, e através de micrótomo rotativo.

Os cortes à mão foram corados com azul de astra e safranina (Bukatsch 1972 apud Krauss e Arduim [26] ) e, posteriormente, montados em lâminas histológicas com glicerina líquida 50\%.

Para obtenção dos cortes em micrótomo rotativo, o material foi incluído em parafina segundo a metodologia descrita por Sass [45], Johansen [24] ou Kraus e Arduim [26] ou em historresina. Para inclusão em parafina, o material foi previamente desidratado em série butanólica terciária [24, 45]. A inclusão por historresina seguiu o procedimento indicado pelo fabricante (Leica). Nos cortes seriados em parafina foram testadas as colorações azul de astra e safranina (Bukatsch 1972 apud Kraus e Arduim [26]). Realizou-se a montagem das lâminas histológicas com bálsamo do Canadá. Os cortes em historresina foram corados com azul de toluidina. 
Os testes microquímicos foram realizados empregando-se Sudan IV para substâncias lipídicas, como suberina e cutina [18] e floroglucinol acidificado para ligninas [24]. Para lipídios, o material controle foi tratado previamente com clorofórmio e metanol segundo Herr e Peterson [22]. Para visualização das estrias de Caspary e estruturas suberificadas utilizou-se também a coloração fluorescente hemisulfato de berberina segundo Lux e Luxová [27].

Para a germinação de Tradescantia spathacea foram coletadas cinqüenta sementes e germinadas na câmara de germinação com fotoperíodo (Eletrolab) do Laboratório de Anatomia Vegetal, Departamento de BotânicaIBUSP. O desenvolvimento do sistema caulinar subterrâneo desta espécie foi acompanhado periodicamente até a planta atingir 6 meses de idade. 


\section{Resultados}

As espécies Commelina erecta, Dichorisandra tyrsiflora, Floscopa glabrata, Tradescantia spathacea e T. zebrina apresentam desde caules eretos até decumbentes, com crescimento simpodial e com nós e entrenós bem definidos. As folhas de todas as espécies deste trabalho possuem filotaxia alterna espiralada (Fig. 2.1 e 2.2), com uma bainha envolvendo parte ou praticamente todo o entrenó. A Fig. 2.2C ilustra este fato para Dichorisandra tyrsiflora. As espécies estudadas são cosmopolitas com hábitos diversos desde helófitas a anfíbias como Floscopa glabrata.

As espécies Commelina erecta e Floscopa glabrata (Fig. 2.1 e 2.2A-B, respectivamente) possuem sistema subterrâneo difuso, apresentando nós e entrenós bem definidos semelhantes aos ramos aéreos, com crescimento horizontal e superficial, sem espessamento aparente e não apresentam grandes quantidades de reserva. O sistema subterrâneo destas duas espécies pode ser descrito como sóboles.

Em contraste, a espécie Tradescantia spathacea (Fig. 2.1 e 2.2D) apresenta um caule aéreo contraído com folhas dispostas em espiral. O caule subterrâneo possui crescimento geotrópico positivo, com nós e entrenós mais curtos e com grande quantidade de reserva (amido). A representação esquemática (Fig. 2.3) foi realizada a partir da germinação dessa espécie em laboratório (material e métodos), onde se percebeu que uma gema na base do nó cotiledonar gera o sistema caulinar subterrâneo.

A espécie Dichorisandra tyrsiflora possui um caule aéreo bem desenvolvido, espesso e pode atingir até 2 metros de altura formando grandes 
arbustos. Possui filotaxia alterna espiralada e com nó e entrenós bem definidos. O sistema subterrâneo é reduzido, dificultando a definição de nós e entrenós, apresentando crescimento plageotrópico e com grande quantidade de reserva (Fig. 2.1 e $2.2 \mathrm{C}$ ).

Em Tradescantia zebrina (Fig. 2.1 e 2.2E) não há parte subterrânea, a planta cresce plagiotropicamente sobre o solo, formando estolões.

As cinco espécies analisadas apresentam semelhanças na organização da estrutura anatômica aérea e na subterrânea quando presente.

Em seção transversal do entrenó do caule aéreo de Floscopa glabrata pode-se observar a epiderme, o córtex estreito em relação à medula (Fig. 2.4AC) e os feixes vasculares distribuídos ao acaso, constituindo o estelo do tipo atactostelo com uma concentração de feixes maiores na região perimedular, no limite entre o córtex e o cilindro vascular (Fig. 2.4A-F). Neste limite, nota-se a presença de dois tecidos importantes no corpo primário da planta: a endoderme e o periciclo (Fig. 2.4B-E).

Próximo ao ápice, a endoderme e o periciclo geralmente se encontram parenquimáticos (Fig. 2.4B, 2.5C, 2.12A, 2.14A-C, 2.18B-D, 2.20B). Porém, em regiões mais afastadas do ápice (Fig. 2.4C, 2.5D, 2.12B, 2.16A, 2.21C) ocorre o espessamente do periciclo. Este é constituído de duas a três camadas espessadas que envolvem os feixes colaterais periféricos, como se vê nas Fig. 2.4C-E. Os feixes colaterais periféricos são formados na região pericíclica e apresentam unicamente, elementos vasculares de metaxilema e metafloema (Fig. 2.4B-E).

No córtex, por ser uma planta anfíbia, observa-se a presença de espaços aéreos, constituindo um aerênquima esquizógeno (Fig. 2.4A-B , 2.4E- 
G), o qual se origina a partir de divisões celulares no córtex, acompanhadas de expansão celular. Internamente aos feixes periféricos estão os feixes vasculares dispostos no cilindro central que apresentam protoxilema, protofloema (além de metaxilema e metafloema) constituindo os traços foliares. Em mais detalhes, nas Fig. 2.5A-D, pode-se notar o traço foliar e os feixes periféricos caulinares envoltos pela endoderme, evidenciada pela fluorescência. É possível perceber na Fig. 2.5B que os traços são envolvidos por fileiras de textura igual a do periciclo (Fig. 2.5D).

Na região nodal de F. glabrata (Fig. 2.6A-D) nota-se a endoderme com estrias de Caspary e o periciclo formando uma região com grande atividade meristemática. A região pericíclica é constituída por uma porção com grande atividade meristemática e outra formada de células com paredes espessadas. Na primeira porção pode-se notar a formação de novos feixes (Fig. 2.6A-D).

Com relação à continuidade dos tecidos, no ápice caulinar de F. glabrata a endoderme e o periciclo são contínuos, respectivamente, ao meristema fundamental e ao procâmbio desde o segundo nó (Fig. 2.7A-C). Na região do nó, esta continuidade também é observada na saída dos traços foliares, onde pode-se notar (Fig. 2.8A-B) a endoderme envolvendo o traço. Na Fig 2.8C-D nota-se também a continuidade da endoderme nas saídas de raízes. Adjacente às raízes, verifica-se a formação de plexos periféricos; os feixes do plexo correm ora externamente, ora internamente aos feixes periféricos indo em direção às raízes adventícias como se percebe também nas Fig. 2.9A-G. Observa-se a presença de dois cilindros vasculares (Fig. 2.9A-B) correspondentes ao que se vê em Tradescantia zebrina (Fig. 2.13A-D). 
A porção caulinar subterrânea de Floscopa glabrata apresenta as mesmas características anatômicas da parte aérea. No entanto, nesta porção, a endoderme e o periciclo tornam-se mais espessados quando comparados à parte aérea e há uma maior formação de raízes adventícias devido à atividade do periciclo (Fig. 2.10A-E). Outra característica importante é a formação de grandes plexos vasculares para as saídas de raízes (Fig. 2.10E).

No ápice vegetativo de $T$. zebrina nota-se a presença de cordões de procâmbio na região central do entrenó que se dirigem aos primórdios foliares (Fig. 2.10A-B). Na mesma direção, na periferia do entrenó, observa-se a presença de inicial endodérmica adjacente ao periciclo, este com células de núcleos mais alongados (Fig. 2.11C-D). Na região nodal, onde se vê uma gema axilar (Fig. 2.11E-F) observam-se cordões de procâmbio contínuos com a região onde se encontra a endoderme e o periciclo; nesta região há formação de novos feixes devido à atividade do periciclo (Fig. 2.11F).

Como já visto em F. glabrata, no entrenó de $T$. zebrina, o córtex se apresenta pouco espessado e os feixes do cilindro vascular se distribuem na sua maioria na periferia (região perimedular), envoltos pela endoderme e pelo periciclo, que juntamente com os feixes medulares, constituem um verdadeiro atactostelo; alguns dos feixes medulares constituídos de protoxilema, protofloema, metaxilema e metafloema (Fig. 2.12C e E) são traços foliares. Em regiões mais jovens, a endoderme e o periciclo permanecem parenquimáticos, podendo apresentar amido e/ou estrias de Caspary (Fig. 2.12A); em regiões mais maduras ocorre o espessamento de ambos (Fig. 2.12B).

Em T. zebrina, na região nodal, ocorre uma fusão dos feixes vasculares de dois nós consecutivos (Fig. 2.13A, H) constituindo um complexo vascular; 
desta fusão participam apenas os feixes vasculares (traços e feixes caulinares) localizados no cilindro mais central, enquanto que os feixes do cilindro periférico permanecem inalterados. Ainda, na região do nó, há uma intensa formação de raízes adventícias e de novos feixes vasculares devido à atividade meristemática do periciclo (Fig. 2.13B-G). Adjacente a esta porção ocorre a saída de muitos traços foliares, oriundos do complexo vascular (Fig. 2.13C e 2.13E) com posição perpendicular à superfície do órgão. Ao atravessar o cilindro central o traço passa através do periciclo, da endoderme e de todo córtex até atingir a bainha da folha (Fig. 2.13E). Na região nodal, os feixes caulinares e traços foliares constituem complexos vasculares (Fig. 2.13H).

Em Commelina erecta o caule também é do tipo atactostelo (Fig. 2.14AD). A endoderme se encontra parenquimática, como a camada mais interna do córtex. Observam-se os feixes caulinares periféricos na região pericíclica, envoltos pela endoderme e pelo periciclo. Em algumas regiões do entrenó a endoderme encontra-se com algumas células em divisão e o periciclo espessado (Fig. 2.14C).

No cilindro central, como visto nas espécies anteriores, ocorrem traços foliares e feixes caulinares (Fig. 2.14A-D). Na região do nó (Fig. 2.15A-D) os feixes são providos de uma calota de fibras. Além dos feixes caulinares periféricos, nota-se ainda a presença de ligações vasculares (complexos) na região interna. Adjacentes aos feixes caulinares periféricos a endoderme possui estrias de Caspary (Fig. 2.16A-B). Nesta mesma região, observa-se a saída de traços (Fig. 2.16-C). Nas Fig. 2.16 C e D pode ser observado que além dos feixes periféricos formarem grupos envolvidos por fibras pericíclicas, observa-se, também, o complexo interno aos feixes. 
O sistema subterrâneo (Fig. 2.17A-F) é semelhante ao visto em $F$. glabrata. Ocorre um maior espessamente da endoderme e do periciclo; notase, também, a formação de inúmeras raízes adventícias; nos entrenós pode-se notar os feixes periféricos adjacentes à endoderme espessada (Fig. 2.17B), o traço foliar e o feixe caulinar do cilindro central (Fig. 2.17 D e F).

As espécies $D$. tyrsiflora e $T$. spathacea apresentam tanto na sua parte aérea quanto na sua parte subterrânea, um estelo do tipo atactostelo. No entanto, estas estruturas espacialmente distintas não diferem muito quanto a sua anatomia.

Em T. spathacea a porção aérea é bem reduzida, representando a terça parte do eixo caulinar (Fig. 2.1). No ápice vegetativo se pode observar cordões de procâmbio que correm em direção aos primórdios foliares; nota-se ainda, a presença de um meristema intercalar em formação, constituído de diversas fileiras de células achatas (Fig. 2.18A).

No entrenó (Fig. 2.18B-D), o córtex é estreito e constituído de células isodiamétricas; mais internamente, verifica-se a presença de feixes caulinares periféricos; a endoderme e o periciclo são detectados apenas pela topografia, pois a visualização foi dificultada pela ausência de estria ou de espessamento das camadas pericíclicas. Pode-se notar ainda, a presença de alguns feixes vasculares, distribuídos aleatoriamente no cilindro central constituídos de protoxilema, protofloema, metaxilema e metafloema (traços foliares) e os feixes caulinares formados por metaxilema e metafloema (Fig. 2.18D).

Na região nodal (Fig. 2.19A-C), a endoderme apresenta-se em atividade meristemática produzindo duas a três camadas de córtex e o periciclo forma feixes caulinares, com apenas metaxilema e metafloema (Fig. 2.19B). Na 
porção subterrânea do caule, o periciclo forma inúmeras raízes adventícias e também plexos periféricos (Fig. 2.19E-F). Nas regiões mais maduras pode-se verificar a presença de um tecido de proteção originado a partir de divisões periclinais e anticlinais de células corticais, o súber estratificado (Fig. 2.19D).

Na espécie Dichorisandra tyrsiflora (Fig. 2.20A-H), na seção transversal do entrenó do caule aéreo (Fig. 2.20A), pode-se observar o córtex estreito em relação ao sistema vascular e a medula; os feixes vasculares distribuídos ao acaso (como visto nas espécies descritas acima) constituindo o estelo do tipo atactostelo (Fig. 2.20A-F). Porém, em regiões mais próximas do nó no nível correspondente às Fig. 2.21 A-D estes tecidos retomam a capacidade meristemática, modificando a anatomia da região. Nesta região, a endoderme e o periciclo, dois tecidos importantes no corpo primário da planta, ocorrem apenas como camadas que limitam o córtex do cilindro central (Fig. 2.21A-B).

O inicio da atividade meristemática é verificado pela presença de células menores, que estão em intensa divisão e com núcleo evidente na região entre o córtex e o cilindro central (Fig. 2.21A-C). Nesta faixa meristemática, pode-se notar que células estão sendo produzidas para dentro e para fora. As células que estão sendo produzidas para dentro são de origem pericíclica e irão formar feixes vasculares com elementos de vasos menores que os produzidos diretamente do procâmbio (Fig. 2.21C-D), e as células que estão sendo produzidas centrifugamente são de origem endodérmica e constituem as derivadas da endoderme (Fig. 2.21A-B).

Internamente à faixa meristemática, encontram-se os feixes periféricos originados do periciclo, os traços foliares e os feixes caulinares originados do procâmbio (Fig. 2.21E-G). Os feixes periféricos permanecem na periferia do 
cilindro; já os feixes do interior da medula fusionam-se (traços e feixes caulinares), correndo perpendicularmente ao eixo do órgão em várias direções; somente os traços saem em direção à bainha da folha, no momento da saída o traço passa pelo limite do sistema vascular e saindo envolvido pela endoderme. Já na região subterrânea (Fig. 2.22A-E) foi observada a presença de estrias de Caspary na endoderme e ainda, a formação de plexos periféricos e feixes vasculares envoltos por fibras. Nesta região há uma intensa formação de novos feixes pelo periciclo (Fig. 2.22C-E).

Os testes microquímicos (Fig 2.23) revelaram que a endoderme e o periciclo no entrenó podem ou não apresentar espessamento nas regiões mais maduras do caule. No entanto, os reagentes sudan IV, floroglucionol e cloreto de zinco iodado utilizados para a evidenciação da endoderme e do periciclo não apresentaram resultados satisfatórios. Por outro lado, o teste com fluorescência (hemisulfato de berberina) mostrou-se positivo para estrias de Caspary e para o espessamento, evidenciando que o mesmo apresenta uma natureza distinta do periciclo, concordando que há uma origem para cada camada. 


\section{Discussão}

De acordo com Tomlinson [52] a família Commelinaceae consiste de ervas perenes com sistemas subterrâneos rizomatosos e geralmente suculentos. No entanto, o sistema subterrâneo das cinco espécies analisadas diferem morfologicamente, não concordando com o conceito stricto de rizoma. Um rizoma apresenta origem a partir da plúmula [4, 23], constituindo um sistema monopolar de ramificação caulinar plagiotrópica [14], onde o caule é rico em reservas, provido de nós e entrenós marcantes, com gemas protegidas por catafilos e com raízes formadas na região nodal [4].

O sistema vegetativo encontrado nas espécies Floscopa glabrata e Commelina erecta se enquadra no sistema subterrâneo descrito como sóboles por Rizzini e Heringer em 1966 [39], em espécies de Cerrado como sendo difusa, de natureza caulinar e de crescimento horizontal e superficial.

Em contraste, foi verificado que o sistema subterrâneo de Tradescantia spathacea tem sua origem a partir do nó cotiledonar e, ainda, apresenta geotropismo positivo, podendo tratar-se de um rizóforo conforme observado em Vernonia [32] e Smilax [3]. Embora um rizóforo seja morfologicamente semelhante aos rizomas quanto à presença de nós e entrenós marcantes e pela formação do sistema radicular adventício a partir do periciclo, o rizóforo difere do rizoma por ter origem diferente.

De acordo com Menezes [32] o rizóforo corresponde à porção caulinar subterrânea das plantas que apresentam sistema de ramificação caulinar bipolar, ou seja, um sistema aéreo que forma folhas, que possui gemas e um sistema subterrâneo que forma raízes adventícias e outros rizóforos. Da 
mesma maneira, Andreata e Menezes [3] observaram que o rizóforo de Smilax quinquenervia era originado a partir de uma gema localizada no nó cotiledonar. Em outras espécies, como Rhizophora mangle [31], Dioscorea kunthiana [40], e em lanthopappus corymbosus [29] o rizóforo é originado pelo espessamento do hipocótilo. Hayashi [21] também observou a presença do rizóforo em Vernonia herbaceae, planta do cerrado. Segundo Menezes [31], R. mangle apresenta dois tipos de rizóforos: um que se origina do próprio hipocótilo (rizóforo primário) e outro que se origina de ramos laterais (rizóforo secundário). Porém, mais estudos serão necessários para confirmar essa possibilidade em $T$. spathacea.

D. tyrsiflora, de acordo com Raunkiaer [37], é uma fanerófita, pois possui as suas gemas acima de $50 \mathrm{~cm}$ do solo. O sistema subterrâneo é reduzido, dificultando a definição de nós e entrenós, apresenta crescimento plageotrópico e com grande quantidade de reserva. Neste caso, este sistema subterrâneo pode ser classificado como rizoma.

Já o sistema caulinar de $T$. zebrina é semelhante a alguns sistemas caulinares encontrados em Eudicotilêdoneas como Fragaria vesca (Rosaceae) [17]. Holm [23] denomina este tipo de sistema de "runners". Para esse autor, estolões são geralmente delgados, sempre axilares e subterrâneos; e os "runners" também são axilares, no entanto, aéreos. Desta maneira, adotou-se a classificação estolão do tipo epigeu [14], ou seja, um sistema caulinar delgado, com entrenós alongados e crescimento plagiotrópico acima do solo.

Em relação à anatomia caulinar, as espécies analisadas apresentam muitas semelhanças, porém, diferem muito quando comparadas as outras Monocotiledôneas. 
No entrenó o córtex é bem distinto, estreito e sem vascularização. $\mathrm{Na}$ ordem irmã Zingiberales, mais precisamente em Zingiberaceae, o córtex é largo e possui muito feixes, denominados por Tomlinson de feixes corticais, cada um totalmente ou parcialmente envolvido por fibras [52]. De acordo com Silva e Menezes [49], as fibras encontradas ao redor dos feixes são de origem pericíclica e os feixes encontrados no córtex podem ser traços foliares ou feixes caulinares.

Ainda no córtex, em F. glabrata foram encontrados espaços aeríferos. Segundo Seago [47] este aerênquima é encontrado em algumas Angiospermas aquáticas basais (Nympheales) e em Monocotiledôneas basais (Acorales) e, de acordo com o autor, este aerênquima é chamado do tipo "colméia de abelha" expansígeno (honeycomb expansigeny), o qual se origina a partir de divisões celulares oblíquas no córtex, acompanhadas de expansão celular [47, 48].

Nos caules de Commelinaceae distinguem-se duas regiões: a região do nó e a região do entrenó. No limite entre o córtex e o cilindro central do entrenó, a endoderme e periciclo variaram quanto a suas estruturas apresentando desde células parenquimáticas até células espessadas. Esta variação é verificada em entrenós subseqüentes, a partir do ápice. Em entrenós maduros, ocorreu um maior nível de espessamento das paredes de suas células. A presença da endoderme e do periciclo como camada limite entre o córtex e o cilindro vascular denomina o estelo encontrado como um verdadeiro atactostelo. De acordo com Esau [16], o estelo é a unidade resultante da combinação dos tecidos vasculares e tecidos fundamentais associados [15, 20, 35]. A palavra estelo deriva do grego que significa coluna; o seu conceito constitui a base da teoria estelar, a qual diz que o corpo primário 
do caule e da raiz são iguais devido à presença de um cilindro central, o estelo, incluído dentro do córtex. Menezes [30] confirma ser o estelo a unidade composta de xilema e floema primários envolvidos por periciclo, e situado internamente à endoderme, respectivamente. Os caules aqui analisados possuem um estelo do tipo atactostelo. De acordo com Brebner [6], o atactostelo, estelo com cordões ou feixes dispersos, encontrado nas Monocotiledôneas é o mais completo tipo de estelo.

Ainda segundo o conceito estelar [56], as camadas limitantes estão associadas ao tecido vascular primário: o periciclo que circunda os tecidos vasculares e a endoderme que circunda o periciclo. A endoderme é a camada mais interna do córtex [15, 16, 33, 55].

A presença de endoderme nos caules é suportada pelos testes realizados com fluorescência (hemisulfato de berberina) e pela sua própria topologia. Tomlinson [52] acredita que a presença de uma endoderme no caule de Commelinaceae é questionável, por ela não apresentar estrias de Caspary, fato que é irrelevante, pois testes microquímicos e técnicas básicas de anatomia vegetal, muitas vezes não a revelam. Corrobora-se com as premissas de Van Fleet [55], segundo as quais a endoderme é um sistema fisiológico e não apenas uma camada de células com estrias de Caspary; ela pode apresentar além de estrias, suberina, amido (bainha amilífera), cristais, espessamento celulósico e ainda atividade meristemática [33, 34, 53-55, 57].

O periciclo muitas vezes torna-se espessado envolvendo os feixes adjacentes a ele. Tomlinson [52] o denominou de bainha esclerenquimática, sem mencionar tratar-se de periciclo. Verificou-se neste trabalho, que esta bainha possui origem do procâmbio, situando-se no limite do sistema vascular 
e portanto, só pode ser o periciclo, como afirma Menezes et al [33]. Os feixes adjacentes ao periciclo foram denominados de "feixes corticais", por Scott e Priestley [46] e Tomlinson [52]. Neste estudo foi adotado o termo feixes periféricos pericíclicos, pois, estes não estão no córtex e sim no próprio periciclo.

Internamente aos feixes periféricos estão os feixes vasculares dispostos no interior do cilindro central e que apresentam protoxilema, metaxilema, protofloema e metafloema constituindo, os traços foliares, segundo a observação de Menezes [30] e denominados por Scott e Priestley [46] e Tomlinson [52] de feixes medulares.

Os feixes caulinares apresentam, unicamente, metaxilema e metafloema, como também já verificado por Menezes [30] em Velloziaceae; segundo esta autora, o procâmbio origina feixes caulinares (formados unicamente por metaxilema e metafloema) e traços foliares formados por protoxilema e metaxilema, protofloema e metafloema. Segundo Menezes [30] e Alves e Menezes [1] os feixes de origem pericíclica são somente caulinares e apresentam, unicamente, metaxilema e metafloema, conforme visto acima. Esses aspectos foram muito bem salientados por Menezes et al [33] e por Alves e Menezes [1].

Uma observação notável que pôde ser feita neste trabalho é que toda atividade de geração de novos feixes vasculares e raízes adventícias só acontece na região do nó, fato mencionado por Tomlinson [52].

Na região nodal, ocorre a atividade meristemática da endoderme e do periciclo. A endoderme produz parte do córtex no entrenó, região que foi denominada por Menezes et al [33] e Alves e Menezes [1] de Derivadas da 
Endoderme Meristemática (DEM). O periciclo atua na formação de feixes caulinares, plexos radiculares e ainda na formação de raízes adventícias. Em Tradescantia zebrina, Commelina erecta e Floscopa glabrata observou-se, junto aos nós, dois plexos: um interno, formado pela fusão de traços foliares e um externo, pericíclico, formado de raízes adventícias. Para Pizzolato [36], em seu estudo com T. zebrina, o MEP é o gerador de tecidos vasculares na região do plexo periférico externo.

Analisando a continuidade dos tecidos entre o nó e o entrenó, percebese que a endoderme e o periciclo, que são distintos a partir do segundo entrenó, são extremamente versáteis, ora estão como uma única camada delimitando o córtex do cilindro central, ora estão com atividade meristemática produzindo células corticais, células vasculares e raízes adventícias. Isto mostra que a manutenção do corpo primário das Monocotiledôneas é na verdade realizado pela endoderme e pelo periciclo, ambos em atividade meristemática e não pelo meristema de espessamento primário $[5,7-13,36$, 41-44, 51], corroborando o estudo de Menezes et al [33]. Remashree [38] demonstrou em rizomas de Zingiber que o primórdio radicular adventício se diferenciava de maneira endógena da camada por ele denominada endodermóide; ele ainda revela que nesta região a camada endodermóide e o periciclo tornam-se meristemáticos sofrendo divisões periclinais e anticlinais resultando nos primórdios radiculares.

Além da intensa atividade encontrada no nó, os feixes de origem de prôcambio do cilindro central (os traços foliares e feixes caulinares) se fusionam e os traços saem perpendicularmente em direção a bainha da folha, formando o complexo vascular interno, conforme já visto. Este complexo vem 
sendo analisado e discutido há mais de um século. De acordo com Falkenberg (1876 apud [52]) e De Bary (1884 apud [52]) há dois sistemas vasculares: o primeiro constituído dos feixes periféricos, que nunca abandonam o caule e o segundo, pelos feixes do cilindro central, que constituem o sistema foliar, que sairão do caule na região nodal. Esta característica em Commelinaceae é extremamente distinta das outras Monocotiledôneas. Outra importante informação é que a endoderme na região que ocorre a formação de plexos também apresentou estrias de Caspary. Os plexos periféricos foram descritos em outras Monocotiledôneas [25, 28, 52]. Na família Smilacaceae [50] o plexo representa a conexão entre os tecidos do caule, da raiz e traços foliares. Para Gifford e Bayer [19] o plexo é responsável pela formação de raízes adventícias. Para visualização da endoderme no caule foram utilizados vários testes, porém somente um trouxe resultados satisfatórios. Os testes realizados com cloreto de zinco iodado, floroglucinol e sudan IV não apresentaram especificidade para as camadas distintas, corando ou reagindo com a endoderme e o periciclo da mesma maneira. Já o teste realizado com hemisulfato de berberina mostrou uma coloração diferente nas duas camadas. Este fato pode ser explicado pela associação do hemisulfato de berberina com compostos distintos referentes a duas camadas distintas. O comprimento de onda analisado foi padrão utilizando o filtro de excitação com iluminação UV $365 \mathrm{~nm}$ e $420 \mathrm{~nm}$, no entanto, a ligação entre o composto da endoderme e o composto do periciclo gerou comprimentos de onda diferentes, gerando assim, cores diferentes como visto na Fig. 2.23.

Após o que foi visto acima e baseados nos resultados obtidos com todas as espécies, pode-se afirmar que, como falam Menezes e colaboradores [33], o 
periciclo é o tecido que sucede o procâmbio na formação dos tecidos vasculares, mas só forma feixes caulinares, isto é, feixes apenas com metaxilema e metafloema.

Como não se observou qualquer espessamento maior, como acontece nas Monocotiledôneas que apresentam bulbos, cormos e rizomas espessados, não se observou uma atividade meristemática intensa da endoderme. Apenas na região do nó verificaram-se divisões a partir de iniciais endodérmicas.

De qualquer maneira estes resultados corroboram plenamente com o estabelicido por Menezes et al [33], segundo as quais a planta é uma unidade e todos os tecidos primários que estão na raiz, estão no caule e estão na folha.

Chama-se a atenção para a presença de um possível rizóforo, ou pelo menos, algo que possa ser considerado um vestígio de um órgão que talvez possa estar presente em outro representante da família. 


\section{Referências}

[1] ALVES, V. F. G.; MENEZES, N. L. de. 2008. Morpho-Anatomical Analysis of the Rhizome in Species of Scleria Berg. (Cyperaceae) from Serra do Cipó (MG). Brazilian Archives of Biology and Technology.

[2] ALVES, V. G.; MELO-DE-PINNA, G. F.; ARRUDA, R. C.; SILVA, C. G.; SCREMIM DIAS, E.; MENEZES, N. L. de. Pericycle and endodermis in monocotyledons. In: Abstracts: XVII International Botanical Congress, 2005, Vienna, Austria, Europe.

[3] ANDREATA, R. H. P.; MENEZES, N. L. de. 1999. Morfoanatomia do embrião, desenvolvimento pós-semifinale origem do rizóforo de Smilax quinquenervia Vell.(Smilacaceae). Boletim de botânica da Universidade de São Paulo, v.18, p.39-51.

[4] APPEZZATO-DA-GLORIA, B., 2003. Morfologia de sistemas subterrâneos: histórico e evolução do conhecimento no Brasil. Riberão Preto: A. S. Pinto. 80 p.

[5] BALL, E. 1941. The development of the shoot apex and of the primary thickening meristem in Phoenix canariensis Chaub., with comparisons to Washingtonia filifera Wats. And Trachycarpus excelsa Wendl. American Journal of Botany, v.28, n.9, p.820-832.

[6] BREBNER, G. 1902. On the anatomy of Danaea and other Marattiaceae. Annals of Botany, v.16, p.517-552.

[7] DEMASON, D. A. 1979. Function and development of the primary thickening meristem in the Monocotyledon, Allium cepa L. Botanical Gazette, v.140, n.1, p. 5166 .

[8] DEMASON, D. A. 1979. Histochemistry of the primary thickening meristem in the vegetative stem of Allium cepa L. American Journal of Botany, v.66, n.3, p.347350 .

[9] DEMASON, D. A. 1980. Localization of cell division activity in the primary thickening meristem in Allium cepa L. American Journal of Botany, v.67, n.3, p.393-399.

[10] DEMASON, D. A. 1983. The primary thickening meristem: definition and function in Monocotyledons. American Journal of Botany, v.70, n.6, p.955-962.

[11] DEMASON, D. A., 1994. Stem thickening in monocotyledons. In: DENGLER, N. G.; IQBAL, M. Growth patterns in vascular plants. Dioscorides, Portland, Oreg. First citation in article. p. 288-310.

[12] DEMASON, D. A.; DIGGLE, P. K. 1984. The relationship between the primary thickening meristem and the secondary thickening meristem in Yucca whipplei Torr. 
III. Observations from histochemistry and autoradiography. American Journal of Botany, v.71, n.9, p.1260-1267.

[13] DEMASON, D. A.; WILSON, M. A. 1985. The continuity of primary and secondary growth in Cordyline terminalis (Agavaceae). Canadian Journal of Botany, v.63, n.11, p.1907-1913.

[14] DU RIETZ, G. E. 1931. Life forms of terrestrial flowering plants. Acta Phytogeographica Suecica, v.3, p.1-95.

[15] EAMES, A. J.; MACDANIELS, L. H., 1947. An Introduction to Plant Anatomy. New York and London: McGraw-Hill Book Company, Inc. . 427 p.

[16] ESAU, K., 1959. Anatomía Vegetal. Barcelona: Omega S. A. 729 p.

[17] FERRI, M. G. 1969. Plantas do Brasil: espécies do cerrado (Plants of Brazil: species of the cerrado). Ed. Edgard Biicher Ltda. São Paulo. 244p.

[18] GERLACH, P. B., 1984. Botanische Mikrotechinique. Stuttgart: Georg Thieme Verlag. $311 \mathrm{p}$.

[19] GIFFORD, E. M.; BAYER, D. E. 1995. Developmental anatomy of Cyperus esculentus (Yellow Nutsedge). International Journal of Plant Sciences, v.156, n.5, p.622-629.

[20] GIFFORD, E. M.; FOSTER, A. S., 1989. Morphology and evolution of vascular plants. 3 ed. New York: WH Freeman.

[21] HAYASHI, A. H. Morfo-anatomia de sistemas subterrâneos de espécies herbáceo-subarbustivas e arbóreas, enfatizando a origem das gemas caulinares. 2003. Tese de Doutorado. IB/Unicamp, Campinas, SP. 142p.

[22] HERR, D. G.; PETERSON, R. L. 1996. Morphology, anatomy and histochemistry of Fagus grandifolia Ehm. (North American Beech) ectomycorrhizas. . Botanica Acta, v.109, p.64-71

[23] HOLM, T. 1929. The applications of the term "Rhizome". Rhodora, v.31, p.6-18.

[24] JOHANSEN, D. A., 1940. Plant microtechnique. New York: McGraw-Hill.

[25] KRAUSS, B. H. 1948. Anatomy of the Vegetative Organs of the Pineapple, Ananas comosus (L.) Merr Merr. I. Introduction, Organography, the Stem, and the Lateral Branch or Axillary Buds. Botanical Gazette, v.110, n.2, p.159-217.

[26] KRAUSS, J. E.; ARDUIN, M., 1997 Manual Básico de Métodos em Anatomia Vegetal. Rio de Janeiro: EDUR (Ed. Universidade Rural). 198 p.

[27] LUX, A.; LUXOVÁ, M. 2003. Growth and Differentiation of Root Endodermis in Primula acaulis Jacq. Biologia Plantarum, v.47, n.1, p.91-97. 
[28] MANGIN, L. 1882. Origine et insertion des racines adventives et modifications corrélatives de la tîge chez les monocotylédones. Annales Sciences Naturales Botanique, v.14, p.216-363.

[29] MELO-DE-PINNA, G. F. A.; MENEZES, N. L. de. 2002. Vegetative organ anatomy of lanthopappus corymbosus Roque \& Hind (Asteraceae-Mutisieae). Revista Brasileira de Botânica, v.25, n.4, p.505-514.

[30] MENEZES, N. L. de. 1971. Traqueídes de transfusão no gênero Vellozia Vand. Ciência e Cultura, v.23, p.389-409.

[31] MENEZES, N. L. de. 2006. Rhizophores in Rhizophora mangle L: an alternative interpretation of so-called"aerial roots". Anais da Academia Brasileira de Ciências, v.78, p.213-226.

[32] MENEZES, N. L. de; MÜLLER, C.; SAJO, M. G. 1979. Um novo e peculiar tipo de sistema subterrâneo em espécies de Vernonia da Serra do Cipó (Minas Gerais, Brasil). Boletim de botânica da Universidade de São Paulo, v.7, p.33-38.

[33] MENEZES, N. L. de; SILVA, D. C.; ARRUDA, R. C. O.; MELO-DE-PINNA, G. F.; CARDOSO, V. A.; CASTRO, N. M.; SCATENA, V. L.; SCREMIN-DIAS, E. 2005. Meristematic activity of the Endodermis and the Pericycle in the primary thickening in monocotyledons: considerations on the "PTM". Anais da Academia Brasileira de Ciências, v.77, p.259-274.

[34] MORITA, M. T.; SAITO, C.; NAKANO, A.; TASAKA, M. 2007. Endodermalamyloplast less 1 is a novel allele of SHORT-ROOT. Advances in Space Research, v.39, n.7, p.1127-1133.

[35] OGURA, Y., 1972. Comparative anatomy of vegetative organs of the Pteridophytes. Gebr. Borntraeger Berlin. 502 p.

[36] PIZZOLATO, T. D. 2006. Procambial initiation for the vascular system in the shoot of Tradescantia zebrina (Commelinaceae). International Journal of Plant Sciences, v.167, n.1, p.59.

[37] RAUNKIAER, C., 1934. The Life Forms of Plants. Oxford University Press, Oxford.

[38] REMASHREE, A. B.; UNNIKRISHNAN, K.; RAVINDRAN, P. N. 1998. Developmental anatomy of ginger rhizomes - II. Ontogeny of buds, roots and phloem. Phytomorphology: An International Journal of Plant Morphology, v.48, n.2, p.155-166.

[39] RIZZINI, C. T.; HERINGER, E. P. 1966. Estudo sobre os sistemas subterrâneos difusos de plantas campestres. Anais da Academia Brasileira de Ciências, v.38, p.85-112. 
[40] ROCHA, D. C.; MENEZES, N. L. de. 1997. O sistema subterrâneo de Dioscorea kunthiana Uline ex R. Knuth (Dioscoreaceae). Boletim de botânica da Universidade de São Paulo, v.16, p.1-11.

[41] RODRIGUES, A. C.; ESTELITA, M. E. M. 2002. Primary and secondary development of Cyperus giganteus Vahl rhizome (Cyperaceae). Revista Brasileira de Botânica, v.25, p.251-258.

[42] RUDALL, P. 1984. Taxonomic and Evolutionary Implications of Rhizome Structure and Secondary Thickening in Iridaceae. Botanical Gazette, v.145, n.4, p.524-534.

[43] RUDALL, P. 1989. Stem Thickening Growth in Bulbous iridaceae. Botanical Gazette, v.150, n.2, p.132-138.

[44] RUDALL, P. 1991. Lateral meristems and stem thickening growth in monocotyledons. Botanical Review, v.57, n.2, p.p150(14).

[45] SASS, J. E., 1951. Botanical Microtechnique lowa State College Press. 228 p.

[46] SCOTT, L. I.; PRIESTLEY, J. H. 1925. Leaf and stem anatomy of Tradescantia fluminensis. Vell. Journal Linnean Society (Botanic), v.47, p.1-28.

[47] SEAGO, J. L. J.; MARSH, L. C.; STEVENS, K. J.; SOUKUP, A.; VOTRUBOVA, O.; ENSTONE, D. E. 2005. A Re-examination of the Root Cortex in Wetland Flowering Plants With Respect to Aerenchyma. Annals of Botany, v.96, n.4, p.565579.

[48] SEAGO JR, J. L.; PETERSON, C. A.; ENSTONE, D. E. 2000. Cortical development in roots of the aquatic plant Pontederia cordata (Pontederiaceae). American Journal of Botany, v.87, n.8, p.1116-1127.

[49] SILVA, C. G.; MENEZES, N. L. D. O espessamento primário em rizoma de Zingiber offinale (Zingiberaceae). In: 58ํㅡㄹ Congresso Nacional de Botânica, 2007, São Paulo, SP, Brasil.

[50] SIMPSON, P. G.; PHILIPSON, W. G. 1969. Vascular anatomy in vegetative shoots of Ripogonum scandens Forsts. (Smilacaceae). New Zealand Journal of Botany, v.7, p.3-29.

[51] STEVENSON, D. W.; FISHER, J. B. 1980. The Developmental Relationship between Primary and Secondary Thickening Growth in Cordyline (Agavaceae). Botanical Gazette, v.141, n.3, p.264-268.

[52] TOMLINSON, P. B., 1969. III - Commelinales-Zingiberales. In Anatomy of the Monocotyledons (C.R. Metcalfe, ed.). Oxford: Clarendon Press 446 p.

[53] VAN FLEET, D. S. 1942. The development and distribution of the endodermis and an associated oxidase system in monocotyledonous plants. American Journal of Botany, v.29, n.1, p.1-15. 
[54] VAN FLEET, D. S. 1950. The cell forms, and their common substance reactions, in the parenchyma-vascular boundary. Bulletin of the Torrey Botanical Club, v.77, n.5, p.340-353.

[55] VAN FLEET, D. S. 1961. Histochemistry and function of the endodermis. The Botanical Review, v.27, n.2, p.165-220.

[56] W, W. C. 1903. Review: The Stelar Theory. New Phytologist, v.2, n.6, p.140144.

[57] XIFREDA, C. C. 1990. Sobre la presencia de una vaina cristalifera en el tallo de algunas especies de Dioscorea (DIOSCOREACEAE). DARWINIANA (ARGENTINA), v.30, n.1-4, p.137-142. 


\section{Representação esquemática dos hábitos das espécies estudadas}

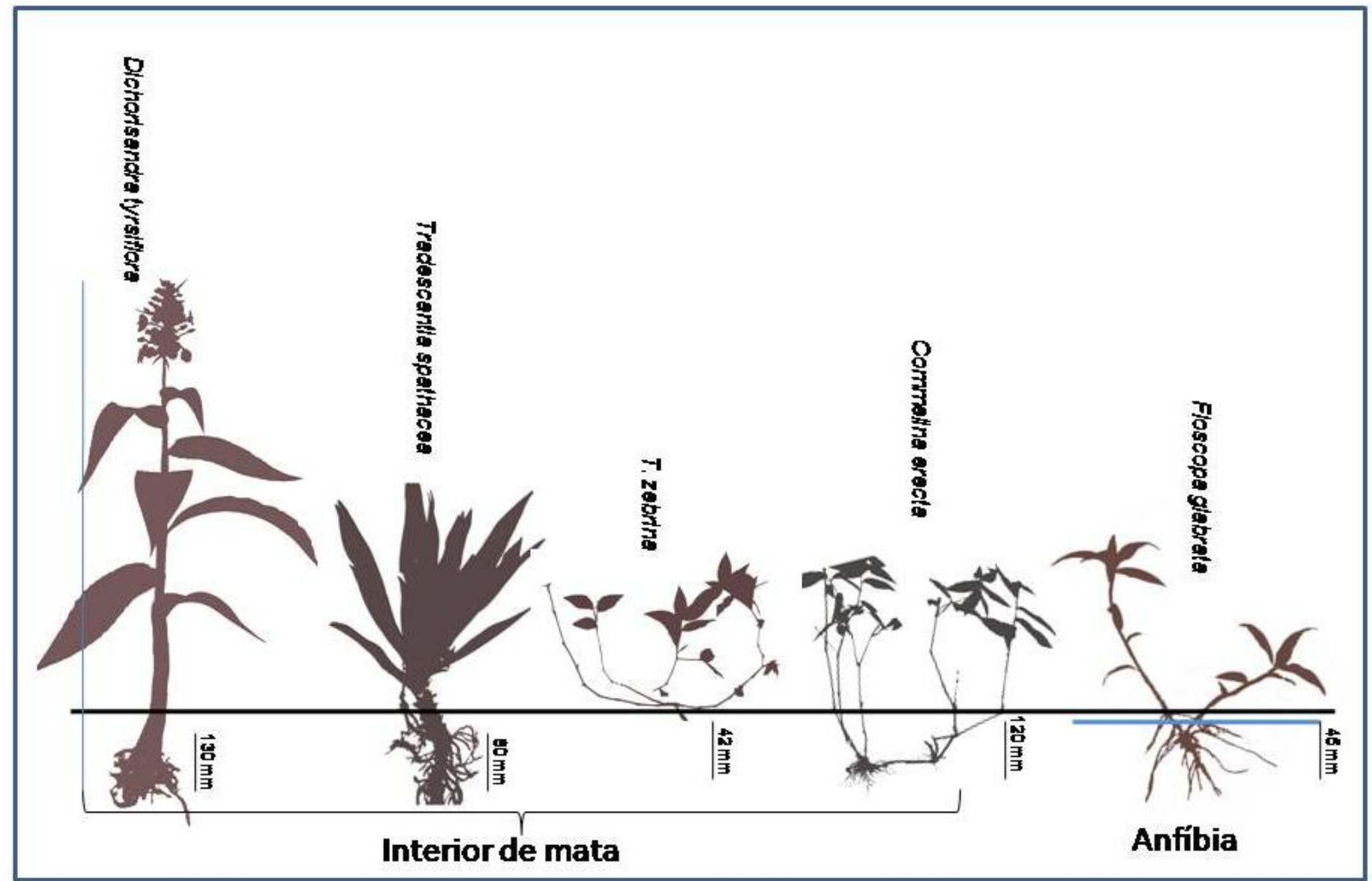

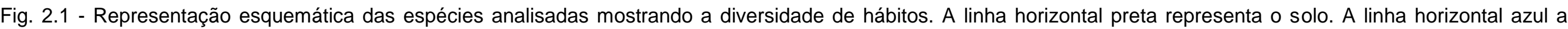
água, pois Floscopa glabrata é uma espécie anfíbia. 


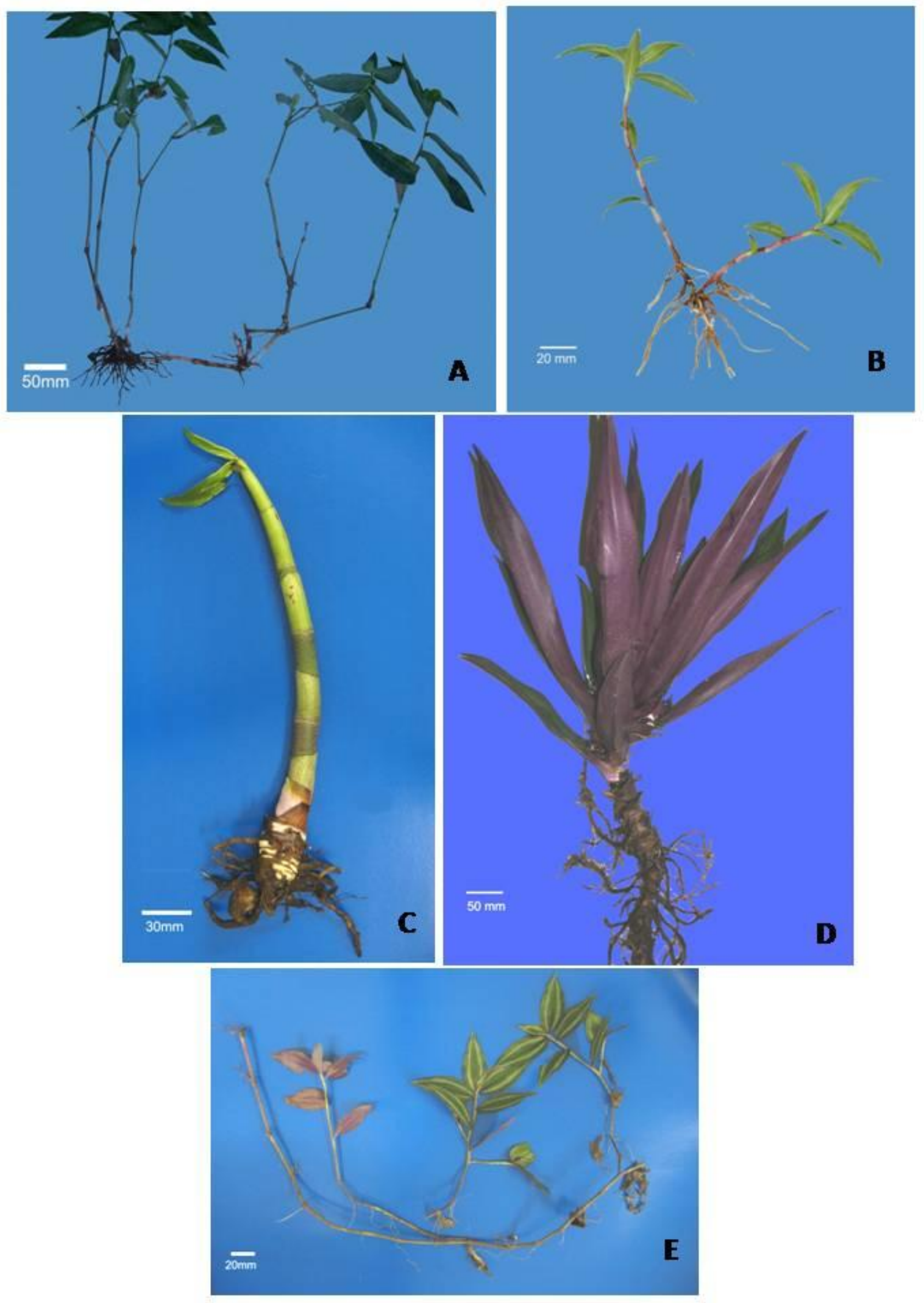

Fig. 2.2A-E - Aspecto geral das espécies (Fig. 2.2A) Commelina erecta, (Fig. 2.2B) Floscopa glabrata, (Fig. 2.2C) Dichorisandra tyrsiflora, (Fig. 2.2D) Tradescantia spathacea, (Fig. 2.2E) Tradescantia zebrina. 


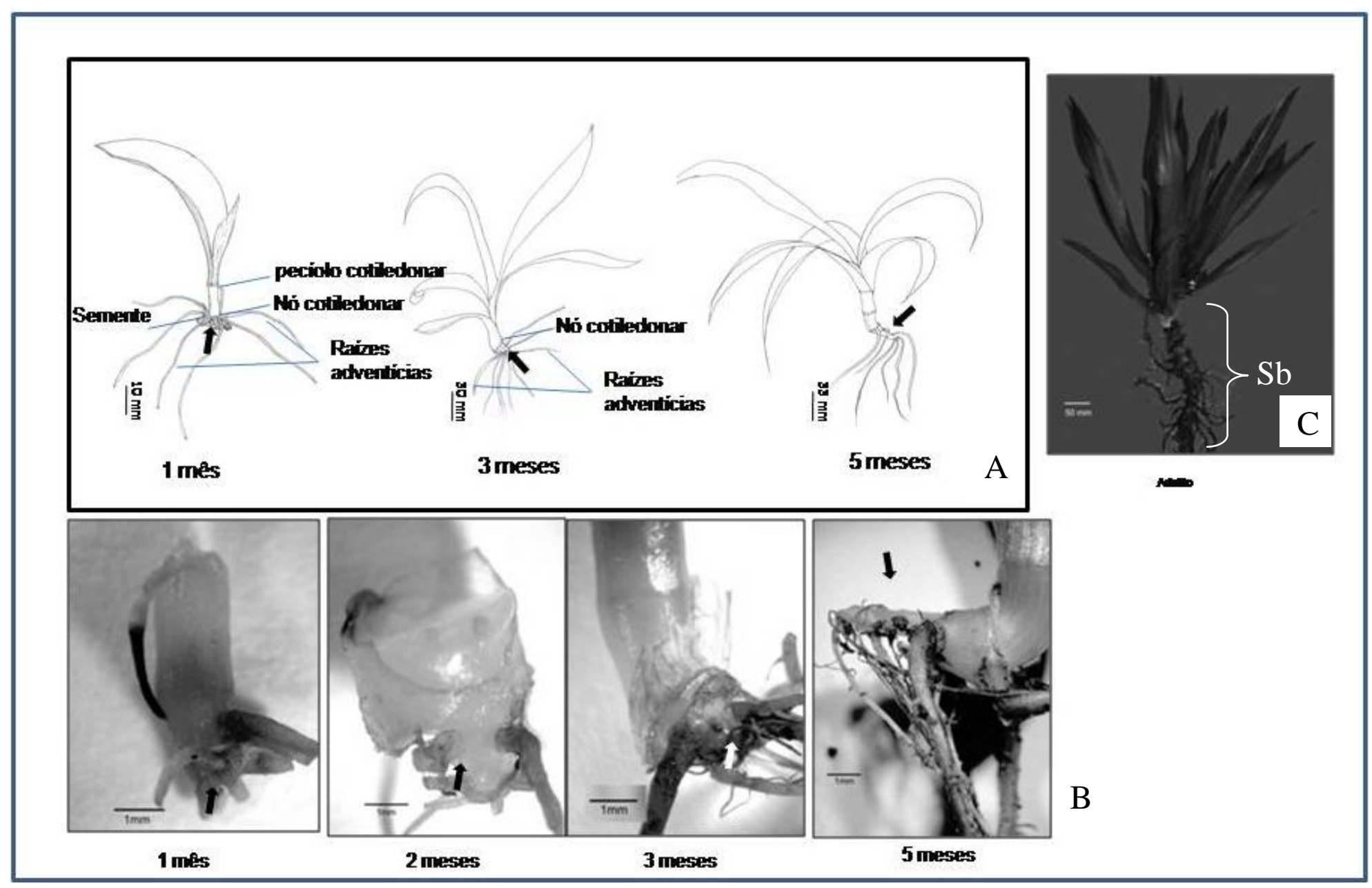

Fig. 2.3 - Representação esquemática do desenvolvimento do eixo caulinar subterrâneo de Tradescantia spathacea (do primeiro ao quinto mês de desenvolvimento). No esquema (Fig. 2.3A) nota-se o desenvolvimento do eixo caulinar a partir da base do nó cotiledonar, abaixo (Fig. 2.3B), em detalhe, a seta indica o eixo caulinar subterrâneo. Fig. 2.3C: 0 indivíduo adulto onde nota-se a porção aérea e a subterrânea $(\mathrm{Sb})$. 

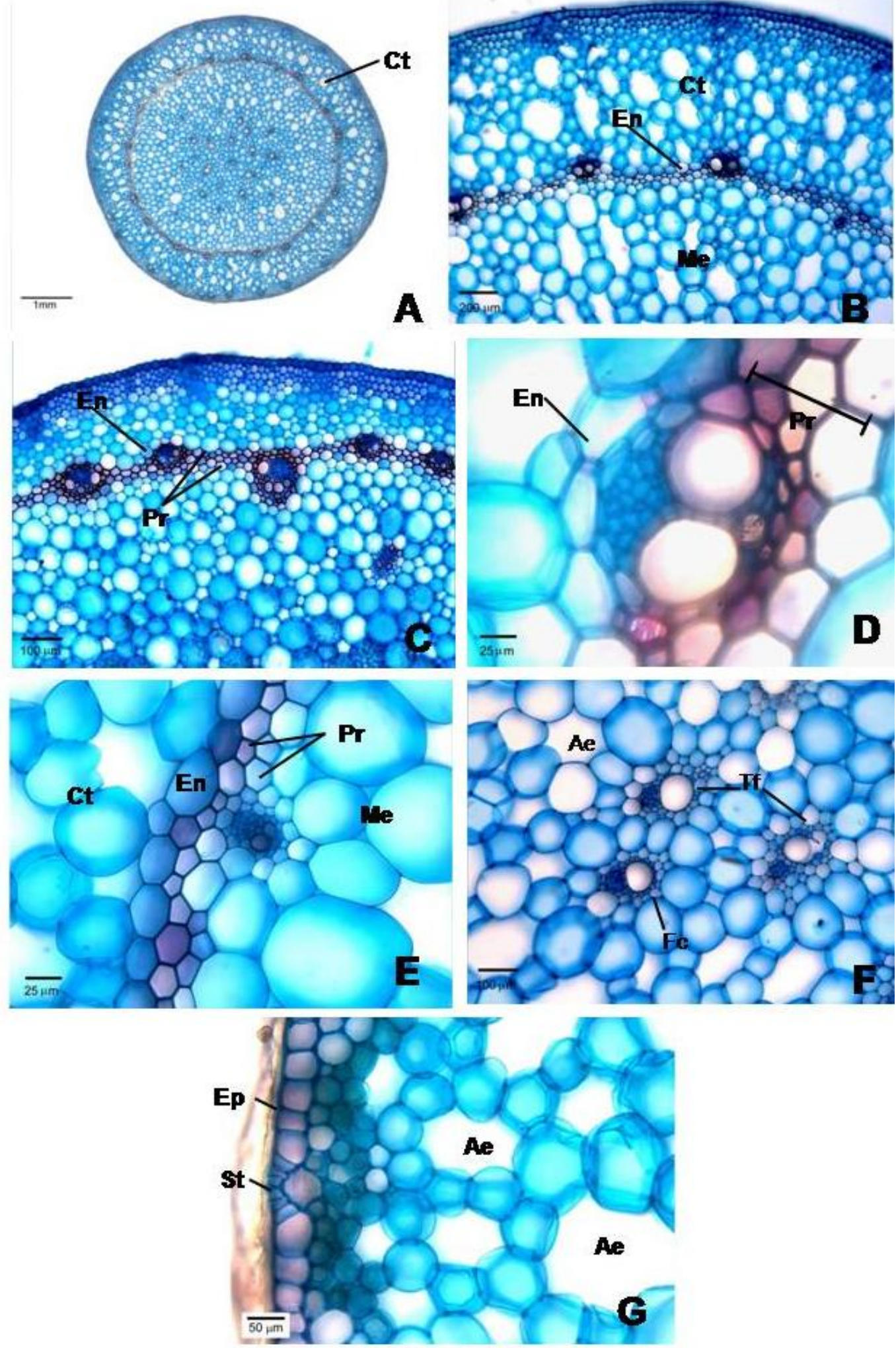

Fig. 2.4A-G - Seções transversais da região do entrenó do caule de Floscopa glabrata (Fig. 2.4A-G) observando-se um córtex (Ct) pouco espesso em relação ao cilindro vascular; verifica-se uma concentração maior de feixes vasculares na região perimedular perfeitamente envolvido por uma endoderme (Fig. 2.4C-E, En). Esses feixes são formados na região pericíclica ( $\mathrm{Pr}$ ). Os feixes medulares são constituídos por poucos elementos vasculares (Fig. 2.4F) e nas regiões cortical e medular (Me) observam-se espaços aéreos. (Fig. 2.4B, E-G, Ae). Ep- Epiderme; Fc- Feixe caulinar; St- estômato, TfTraço foliar. 

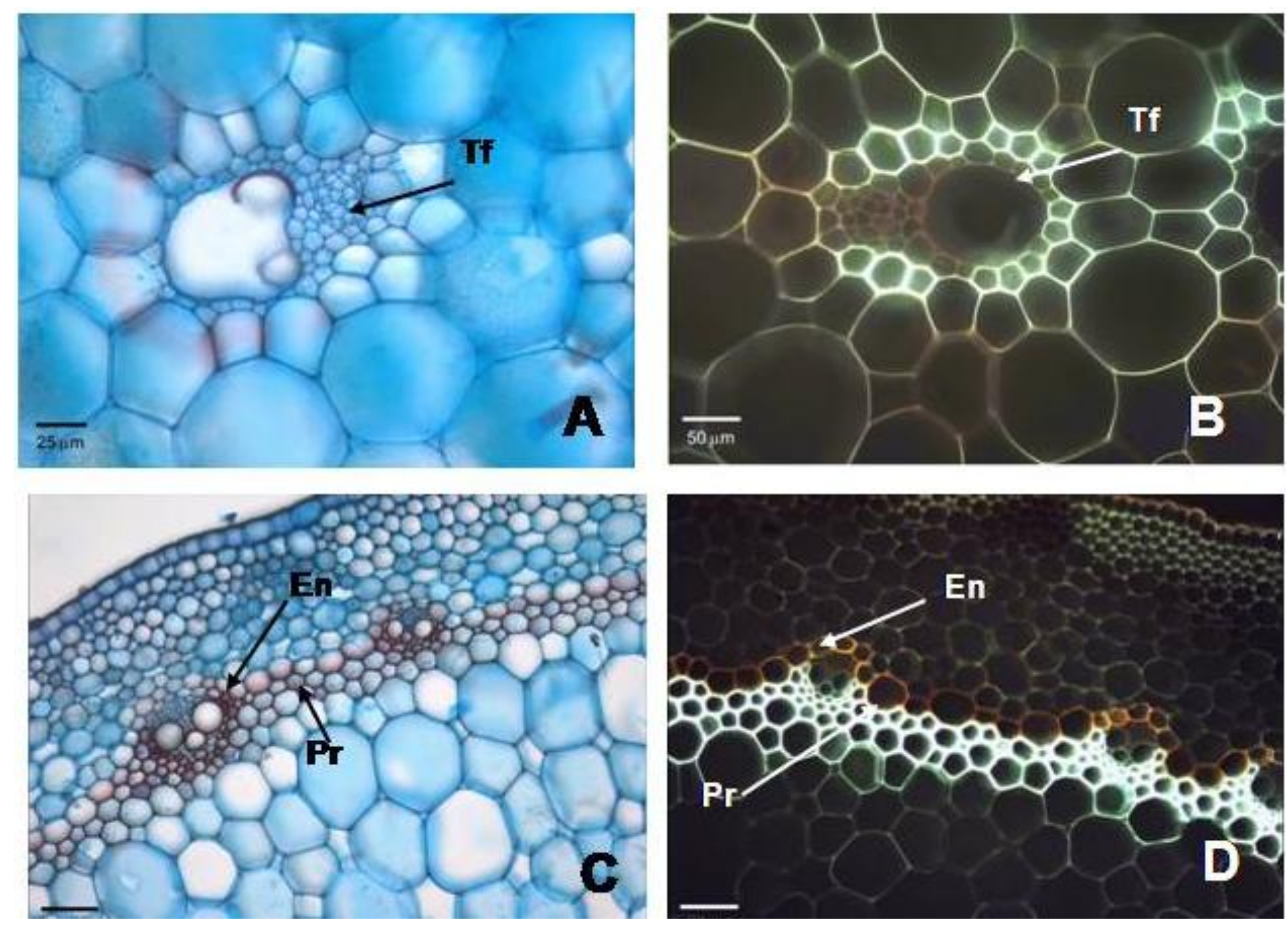

Fig. 2.5A-D - Seções transversais de caule de Floscopa glabrata notando-se dois traços foliares (2.5A e B) e a posição periférica dos feixes caulinares formados pelo periciclo (Pr) envolvidos pela endoderme (En). Nas Fig. 2.5B e D, tratadas com hemisulfato de berberina, sob fluorescência, o traço foliar com calota de fibras, (Fig. 2.5D) sob fluorescência, notando-se a endoderme, bem distinta pela cor laranja e o periciclo na cor branca. 

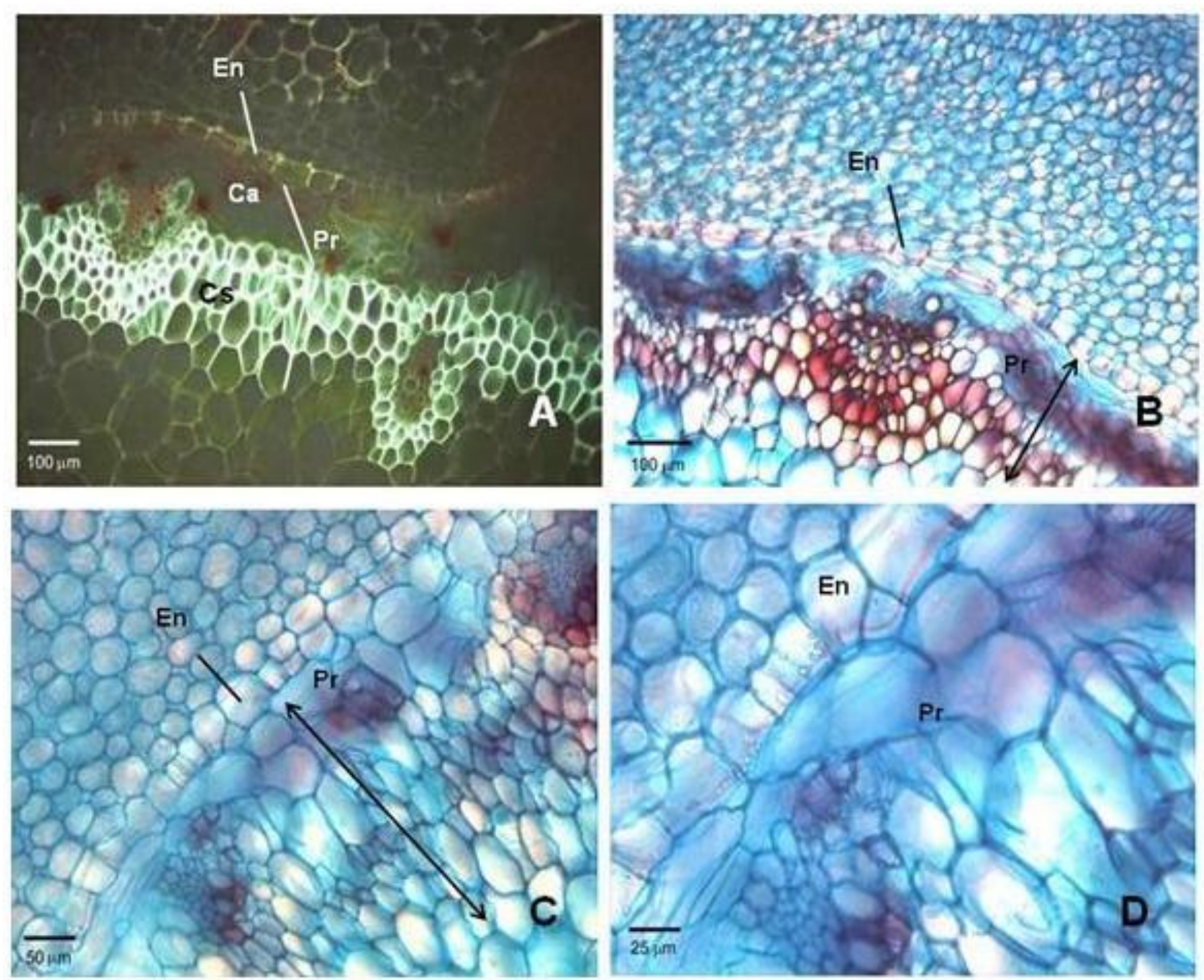

Fig. 2.6A-D - Seções transversais da região do nó de Floscopa glabrata, onde se percebe a região pericíclica (Pr) mais espessada e uma região formada por células em atividade (Ca). Na Fig. 6A a estria de Caspary está realçada por hemisulfato de berberina e na Fig. 6B, com safranina. Endoderme (En). Cs- Células espessadas. 

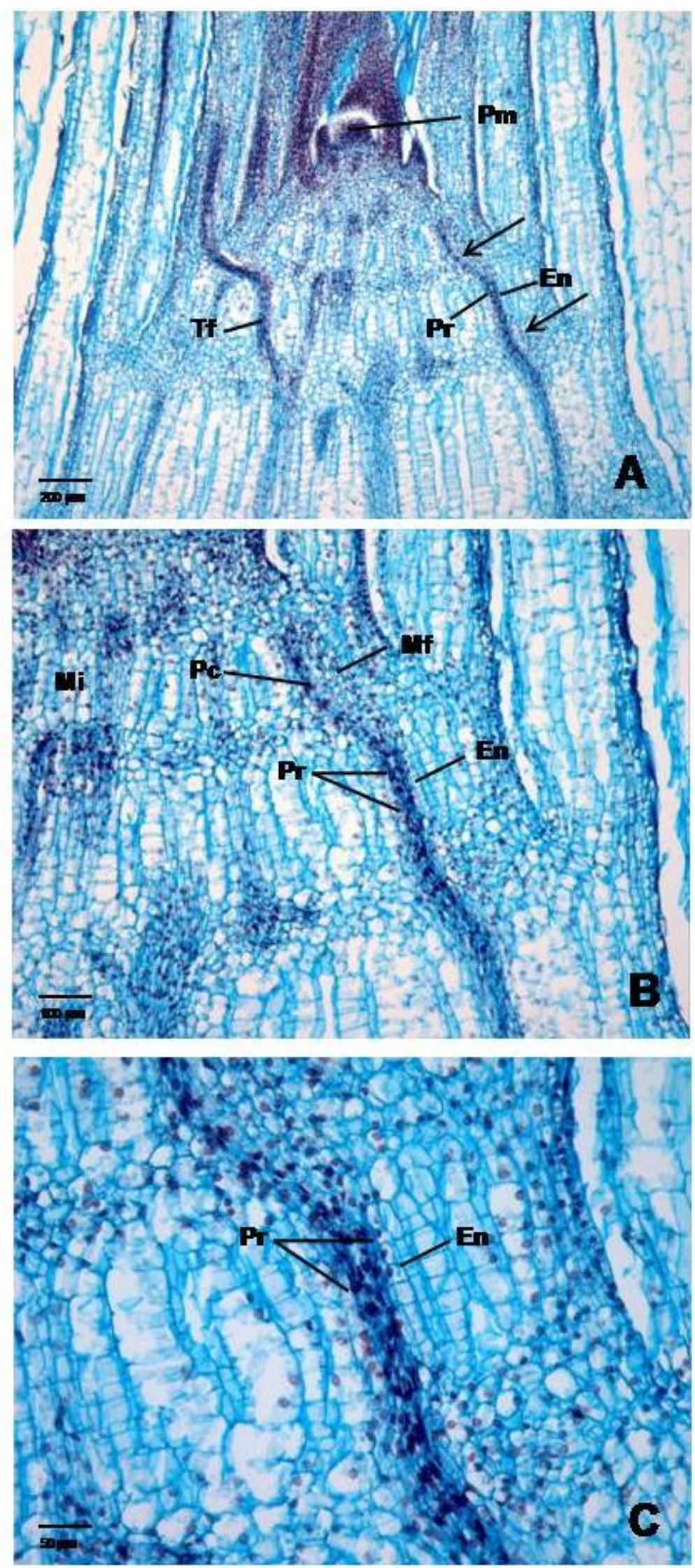

Fig. 2.7A-C. Ápice vegetativo de Floscopa glabrata notando-se células do procâmbio (Pc) e do meristema fundamental (Mf) e na seqüência, o periciclo ( $\mathrm{Pr}$ ) e a endoderme (En). Mi- meristema intercalar.As setas indicam o limite entre o córtex e o cilindro central. 

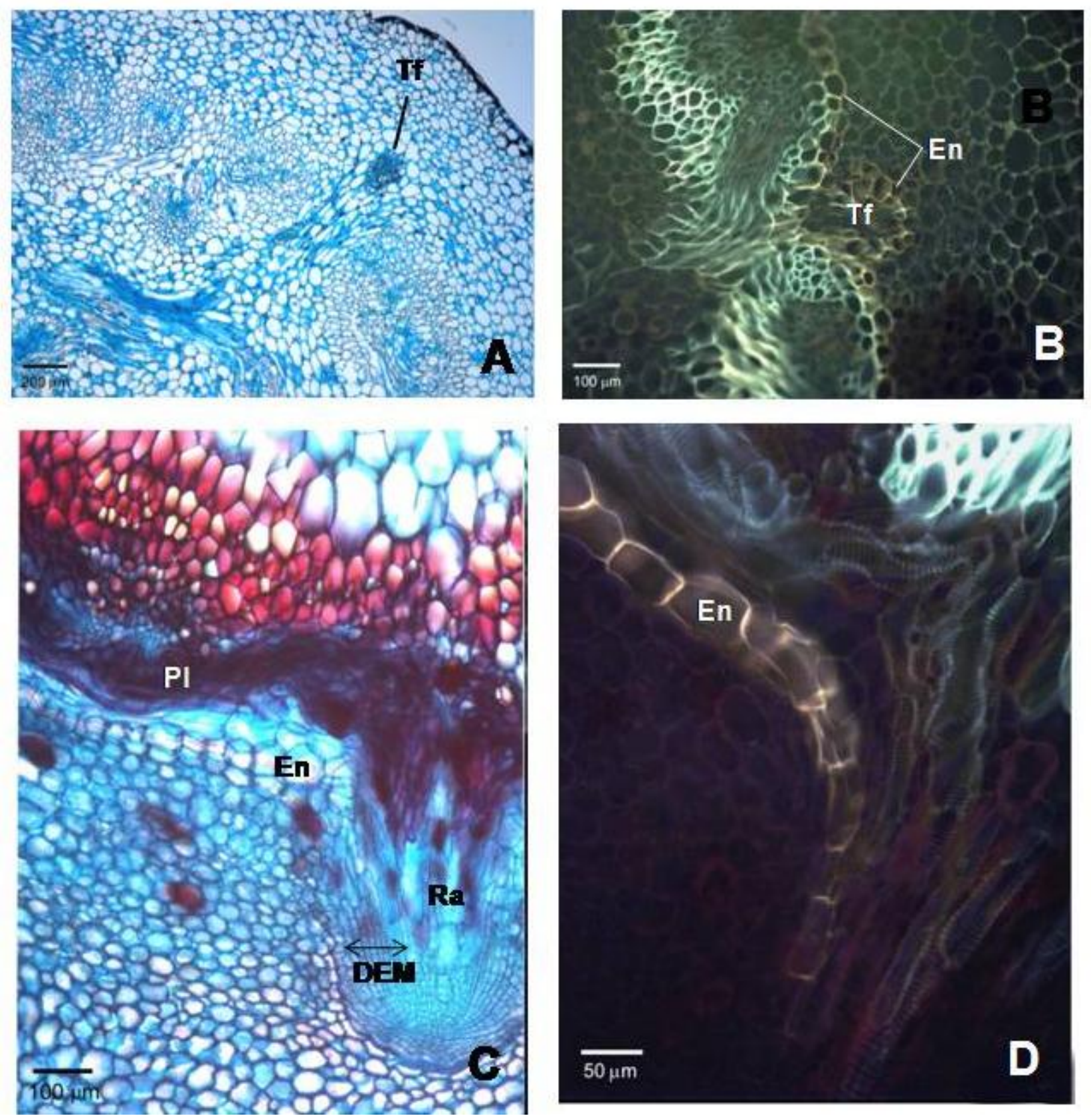

Fig. 2.8A-D - Seções transversais de Floscopa glabrata mostrando a região do nó onde se observa a saída de traços foliares ( $\mathrm{Tf}$ ) envolvidos pela endoderme (En) destacada por hemisulfato de berberina. Fig. 2.8C-D saída de raiz adventícia $(\mathrm{Ra})$ sendo que na Fig. 2.8C observa-se a presença do plexo (PI) em direção à nova raiz, e a endoderme ressaltada na Fig. 2.8D por hemisulfato de berberina. DEMderivadas da endoderme meristemática. 

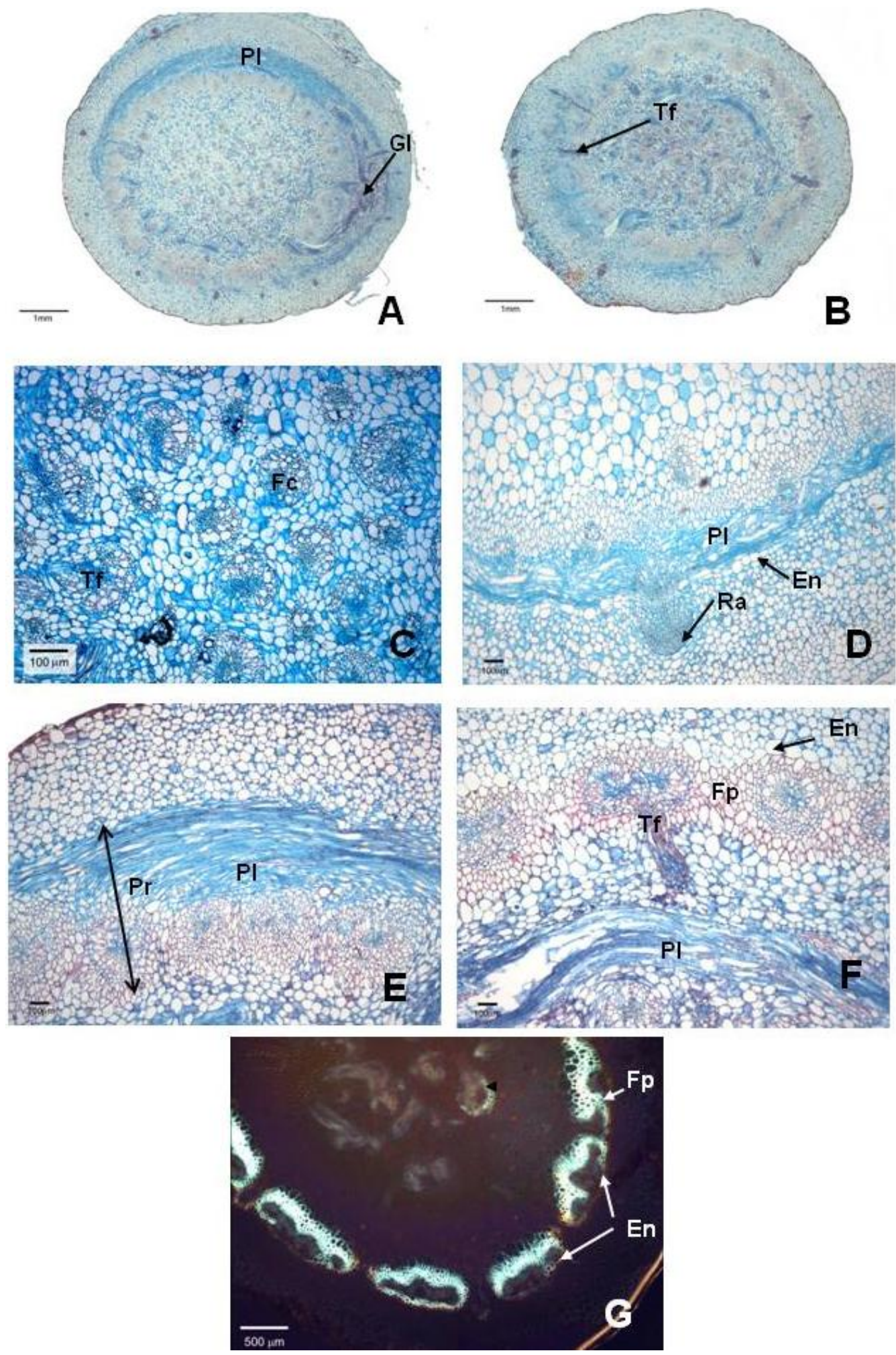

Fig. 2.9A-G. Seções transversais do sistema subterrâneo caulinar de Floscopa glabrata, notando-se o plexo periférico $(\mathrm{PI})$ na região pericíclica (Fig. 2.9A e B), a presença de dois cilindros em $2.9 \mathrm{~B}$, feixes no interior da região medular (Me) (Fig. 2.9C), saída de raiz adventícia (Ra) e respectivo plexo (Fig. 2.9D) e região pericíclica $(\mathrm{Pr})$ com plexo (Fig. 2.9E). Saída do traço foliar (Tf) (Fig. 2.9F) e aspecto geral dos feixes pericíclicos ( $\mathrm{Fp}$ ) envolvidos externamente pela endoderme (En). A Fig. 2.9F mostra feixes periciclícos $(\mathrm{Fp})$ e, internamente, fusão de tecidos vasculares formando um cilindro. Na Fig. 2.9G destaca-se, com auxilio do hemisulafto de berberina, os conjuntos de feixes pericíclicos ( $F p$ ), formando o cilindro vascular. Fc- Feixe caulinar. 

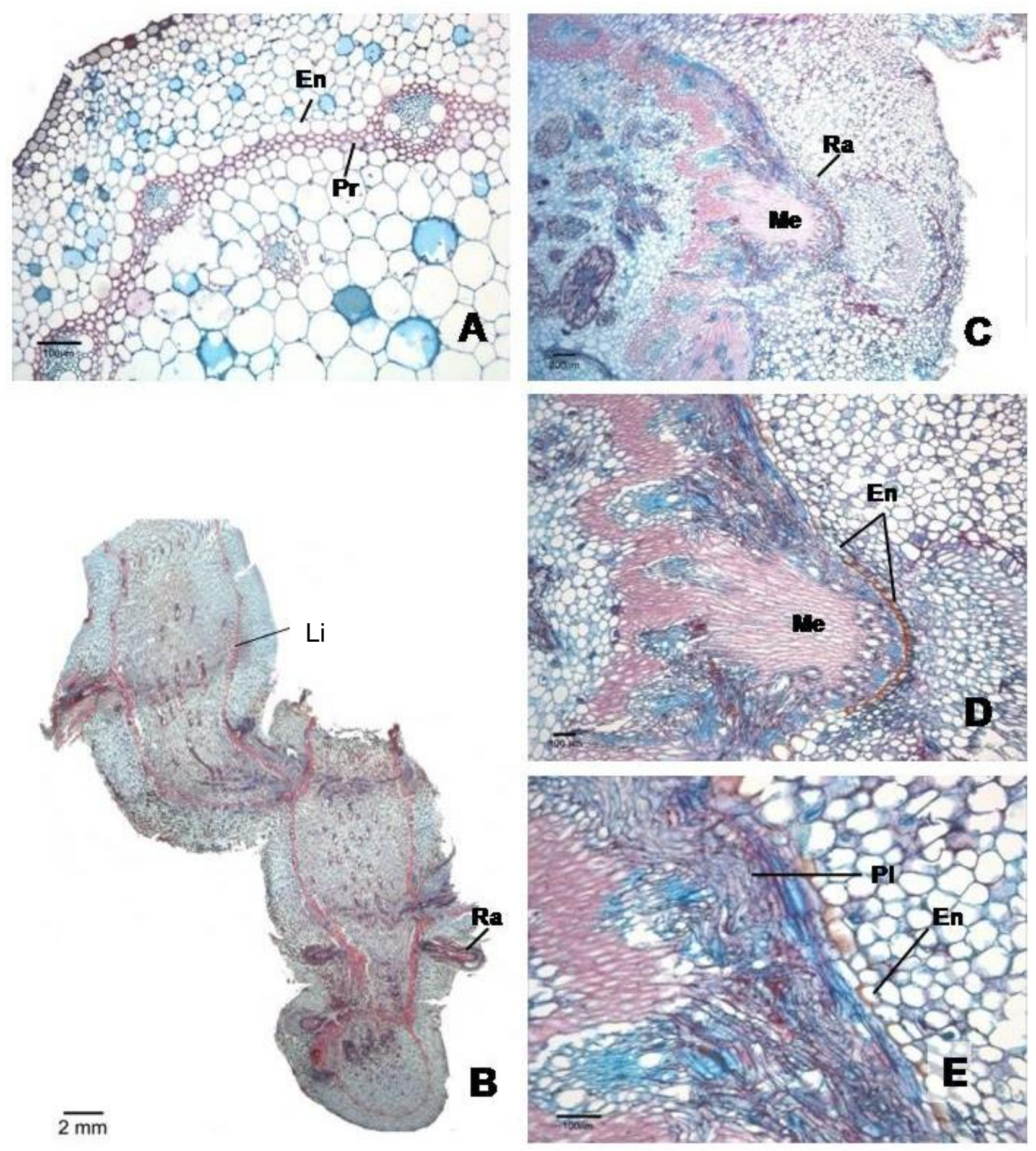

Fig. 2.10A-E - Seções transversais (Fig. 2.10A) e longitudinais (Fig. 2.10B-E) de Floscopa glabrata notando-se saída de raiz adventícia ( $\mathrm{Ra}$ ), com a medula $(\mathrm{Me})$ totalmente lignificada, destacando-se a endoderme (En). A Fig. 2.10 B evidencia bem a natureza simpodial do sistema caulinar. Na Fig. 2.10D e E nota-se na endoderme com espessamento. Li - Limite do cilindro central; PI- Plexo radicular. 

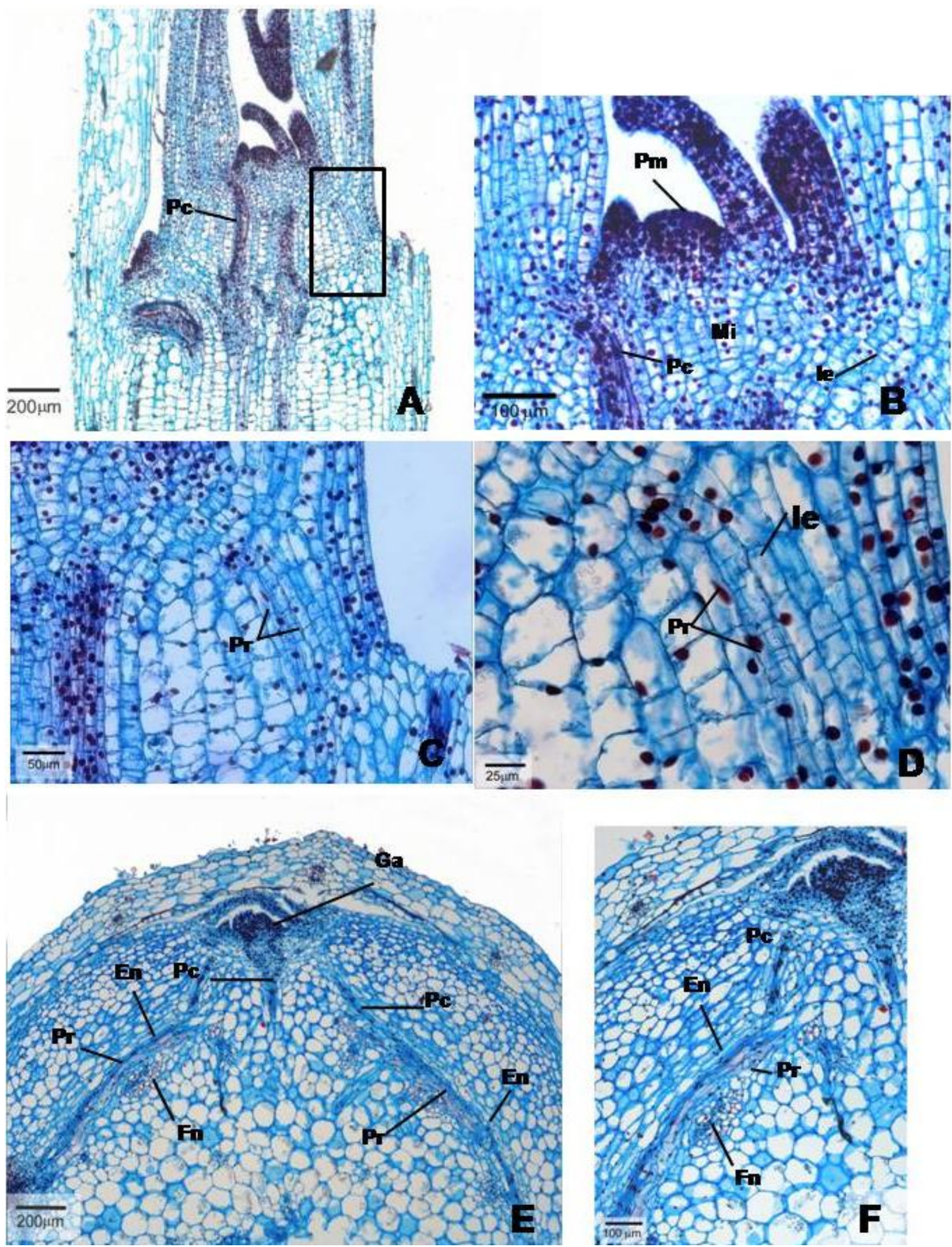

Fig. 2.11A- F - Seções longitudinais do ápice vegetativo de Tradescantia zebrina (Fig. 2.11A-D) e transversais (Fig. 2.11E-F) do caule na região do nó. Os cordões de procâmbio (Pc) podem ser observados na Fig. 2.11A, na região central do entrenó e a Fig. 2.11C é um destaque demarcado na figura $2.11 \mathrm{~A}$, onde se observam a inicial endodérmica (le) e a região pericíclica (Pr). Esta mesma região aparece também na Fig. 2.11D notando-se em ambas, provavelmente uma inicial endodérmica (le). Nas Fig. 2.11E-F, nota-se uma gema axilar $(\mathrm{Ga})$ com o procâmbio em conexão com o periciclo que está formando um feixe novo (Fig. 2.11F, Fn). En- Endoderme, Pm- Pró-meristema. 


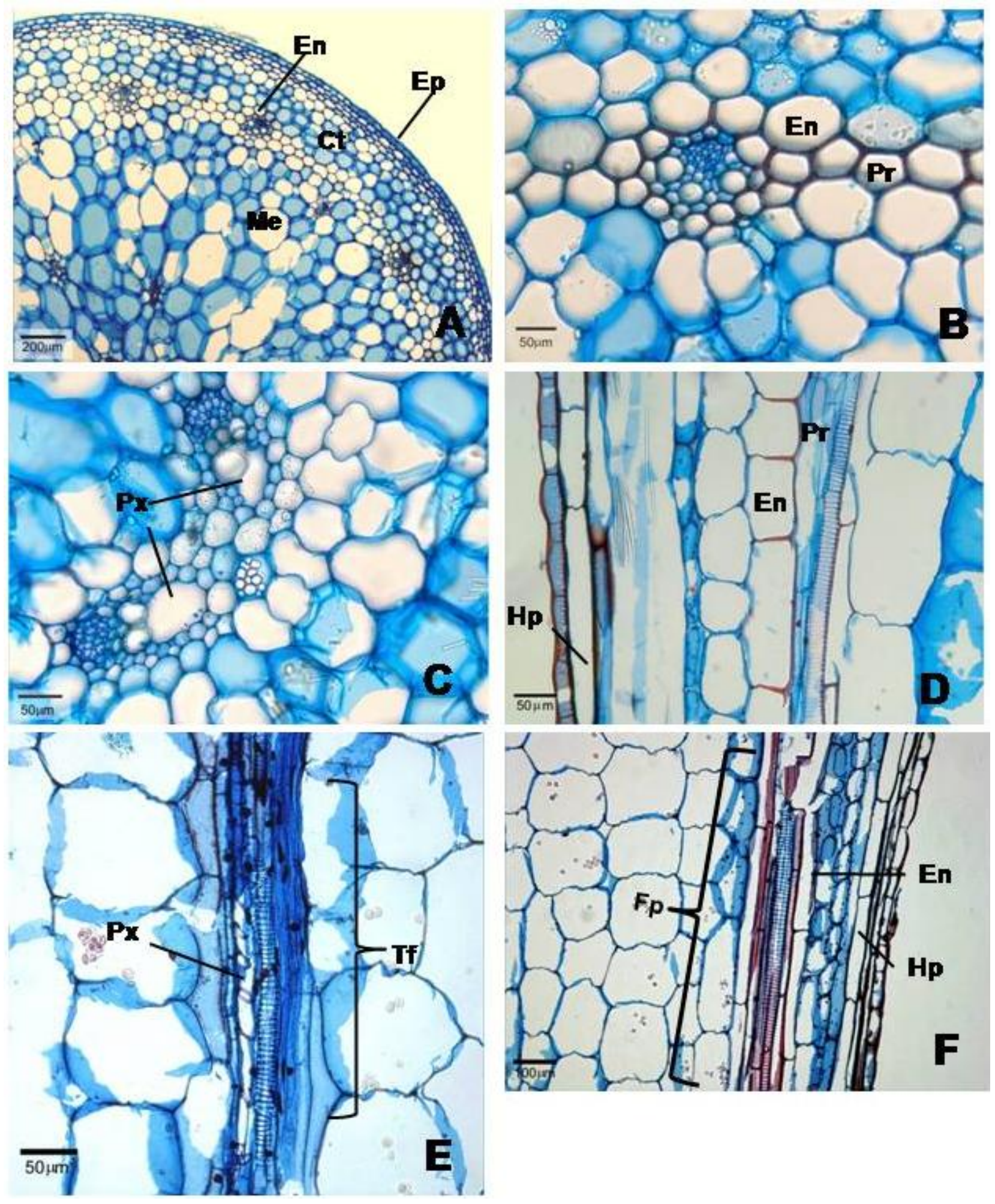

Fig. 2.12A-F.- Seções transversais do entrenó de caule de Tradescantia zebrina (Fig. 2.12A-C) e seção longitudinal (Fig. 2.12D-F). Nota-se o córtex (Ct) estreito e, em detalhe, a endoderme (En) e o periciclo $(\mathrm{Pr})$ unisseriado. Observam-se as lacunas do protoxilema $(\mathrm{Px})$ de dois traços foliares na região da medula (Me) Fig. 2.12C. A endoderme em seções longitudinais (Fig 2.12E e F). Na Fig. 2.12E mostra, em seção longitudinal, o traço foliar ( $\mathrm{Tf}$ ) localizado na região medular; pode-se observar o elemento de protoxilema $(\mathrm{Px})$. Na Fig $2.12 \mathrm{~F}$ o feixe da região perimedular de origem pericíclica (Fp) longitudinalmente. Ep- Epiderme; Hp- hipoderme. 

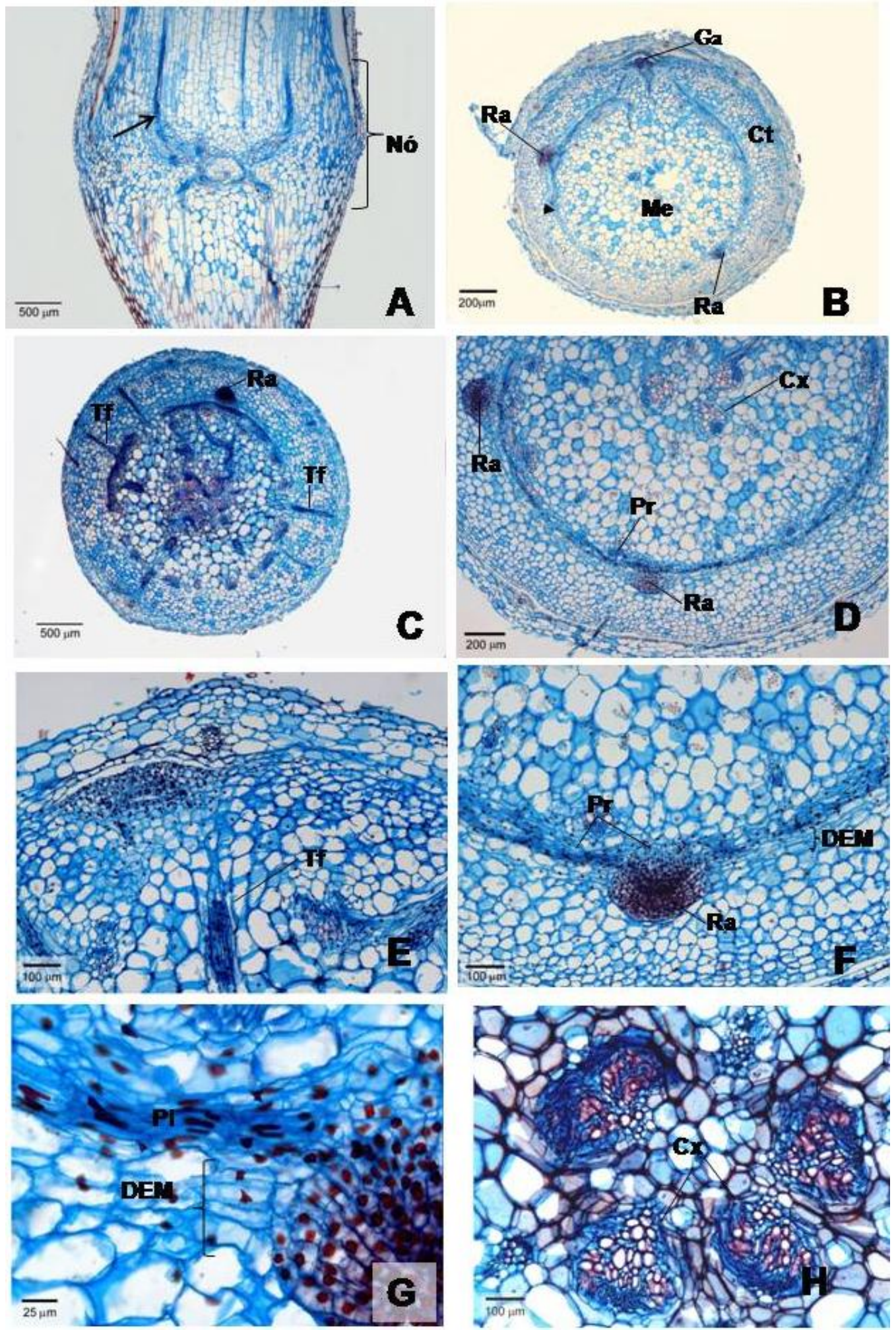

Fig. 2.13A-H - Seções longitudinal (Fig. 2.13A) e transversais (Fig. 2.13B-H) de Tradescantia zebrina, na região do nó. Fig. 2.13A: região do nó onde se observa uma configuração dos feixes vasculares, com certo entrelaçamento entre os feixes de dois nós consecutivos. Fig. 2.13B-F observam-se saídas de raízes adventícias $(\mathrm{Ra})$ e traços foliares (Tf) perpendiculares à superfície do órgão; é perfeitamente clara a formação das raízes adventícias no periciclo ( $\operatorname{Pr}$ ), melhor observado na Fig. 2.13F; e também o plexo (PI) em direção à raiz na Fig. 2.13G. Na Fig. 2.13H, observam-se complexos vasculares $(\mathrm{Cx})$, que correspondem ao indicado por seta na Fig. 2.13A, da região do nó. Ct- Córtex; DEM- derivadas da endoderme meristemática; Ga- Gema axilar; Cv cilindro vascular. 

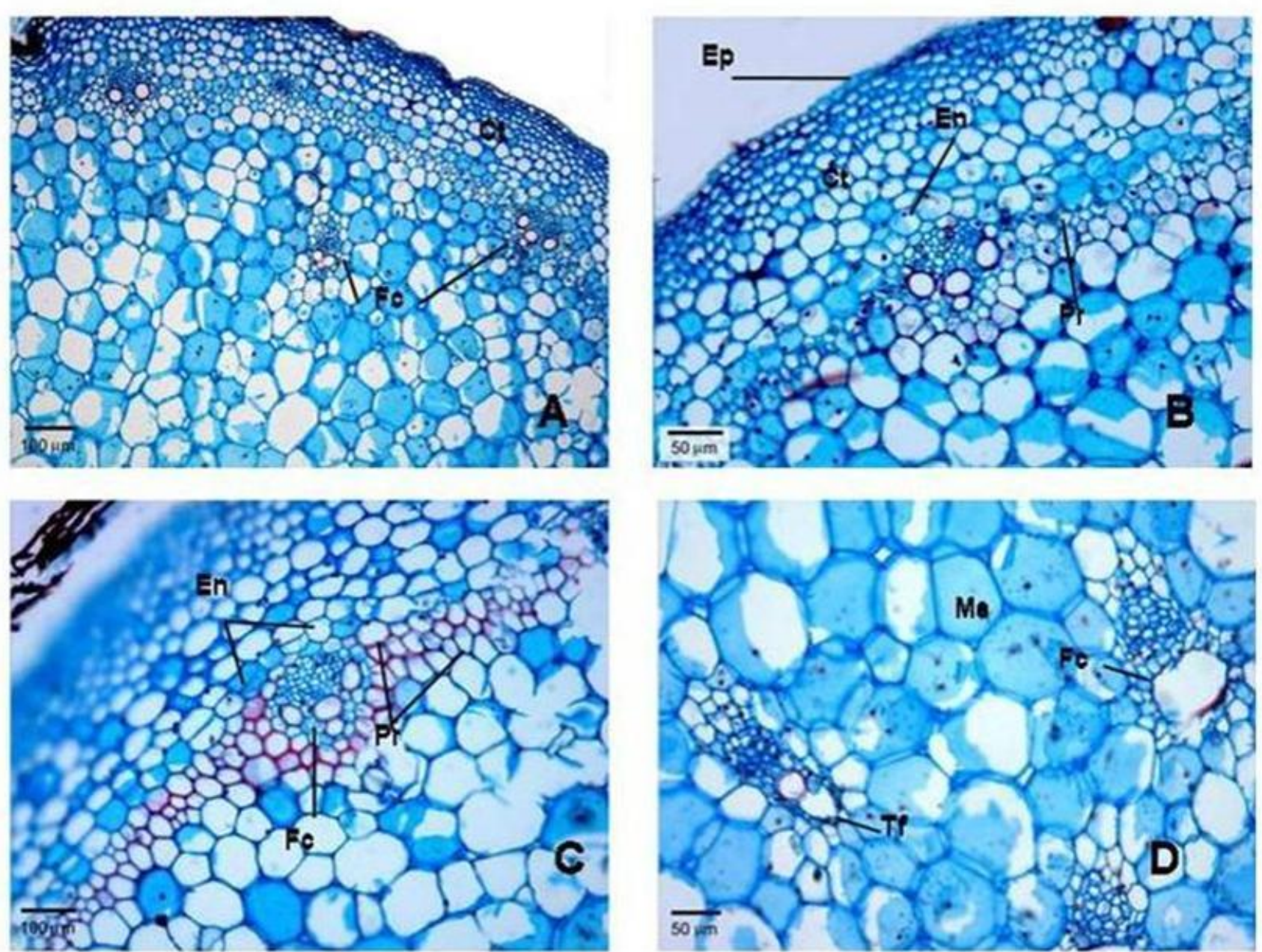

Fig. 2.14A-D - Seções transversais da região do entrenó do caule de Commelina erecta, onde se percebe a endoderme (En) parenquimática como a camada mais interna do córtex (Ct). Observam-se os feixes vasculares caulinares $(\mathrm{Fc})$ na região pericíclica $(\mathrm{Pr})$ perfeitamente envolvidos por uma endoderme, sendo possível observar as células do periciclo espessadas e a endoderme, que em alguns pontos, mostra células em divisão (Fig. 2.14C). Na Fig. 2.14D observam-se traços foliares (Tf) dispostos na medula (Me). Ep- Epiderme. 

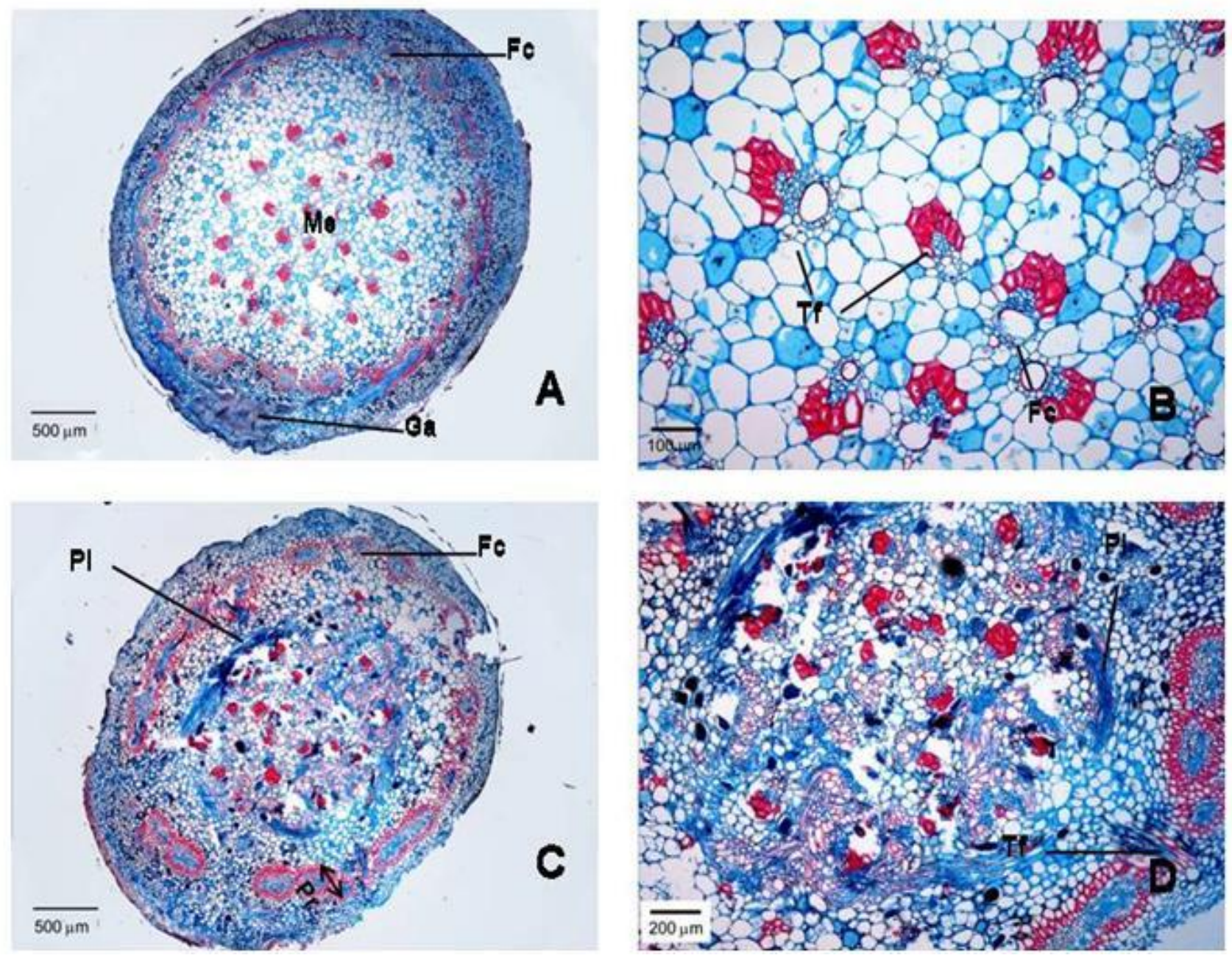

Fig. 2.15A-D - Seções transversais da região do segundo nó do caule de Commelina erecta. Fig. 15A-B: notam-se traços foliares (Tf) providos de uma calota de fibras na região da medula $(\mathrm{Me})$. Fig. 2.15C-D: observam-se, além dos feixes caulinares $(\mathrm{Fc})$ periféricos, a presença de plexos $(\mathrm{PI})$ na região interna. O sistema vascular, na região pericíclica $(\operatorname{Pr})$ aparece separando em porções envolvidas por fibras pericíclicas. 

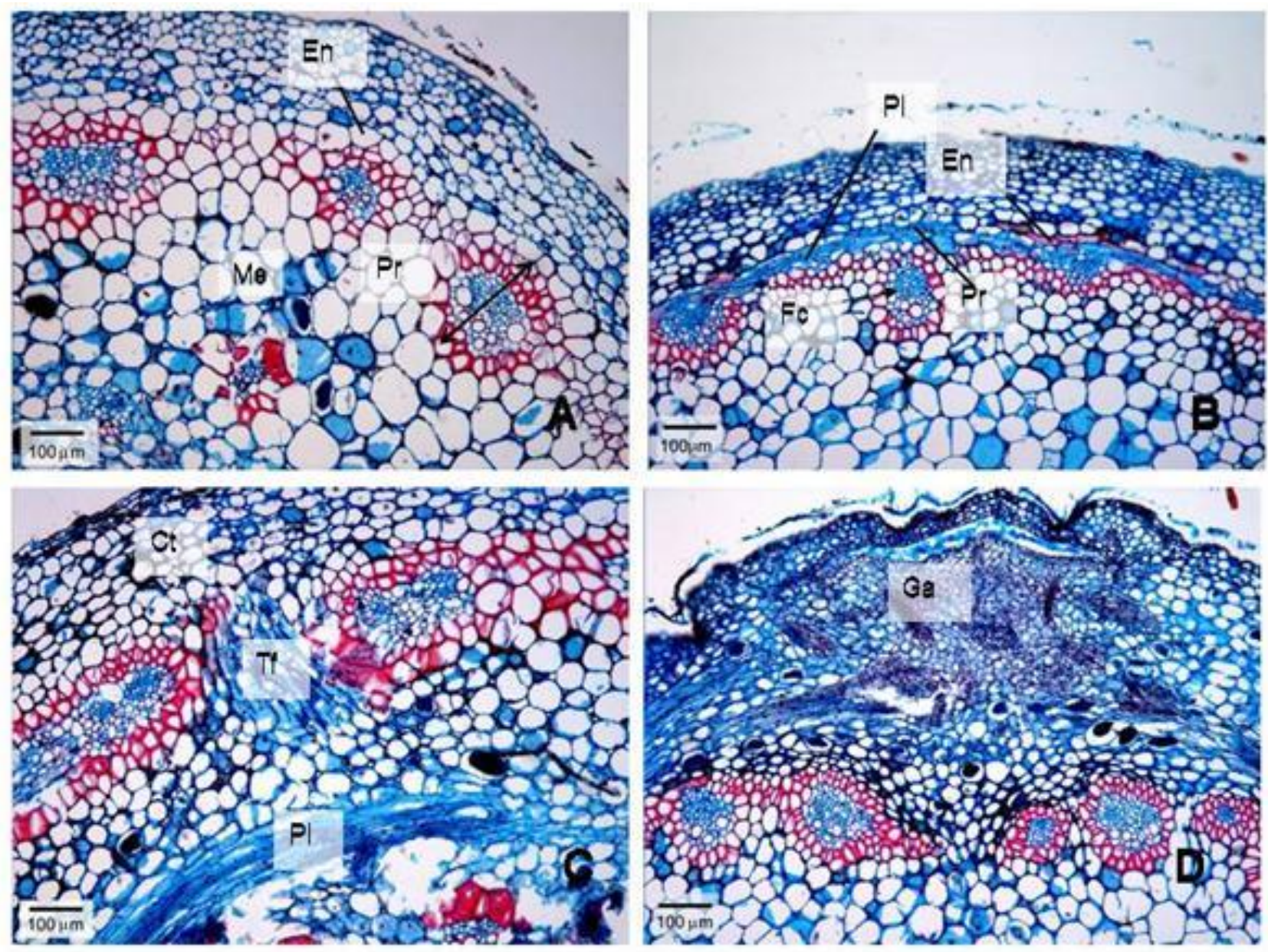

Fig. 2.16A-D - Seções transversais em Commelina erecta da mesma região representada nas Fig 2.16A-D Observam-se os feixes caulinares (Fc) periféricos em grupos menores (Fig. 2.16A) ou maiores (Fig. 2.16C) envolvidos por fibras pericíclicas. Fig. 2.16B a endoderme (En) com estrias de Caspary e o plexo (PI) na região pericíclica (Pr). Fig. 2.16C: saída de traço foliar (Tf) e presença de fusão de feixes internamente ao periciclo (Fig. 2.16D). Ct- Córtex; Ga- Gema axilar; PIPlexo. 


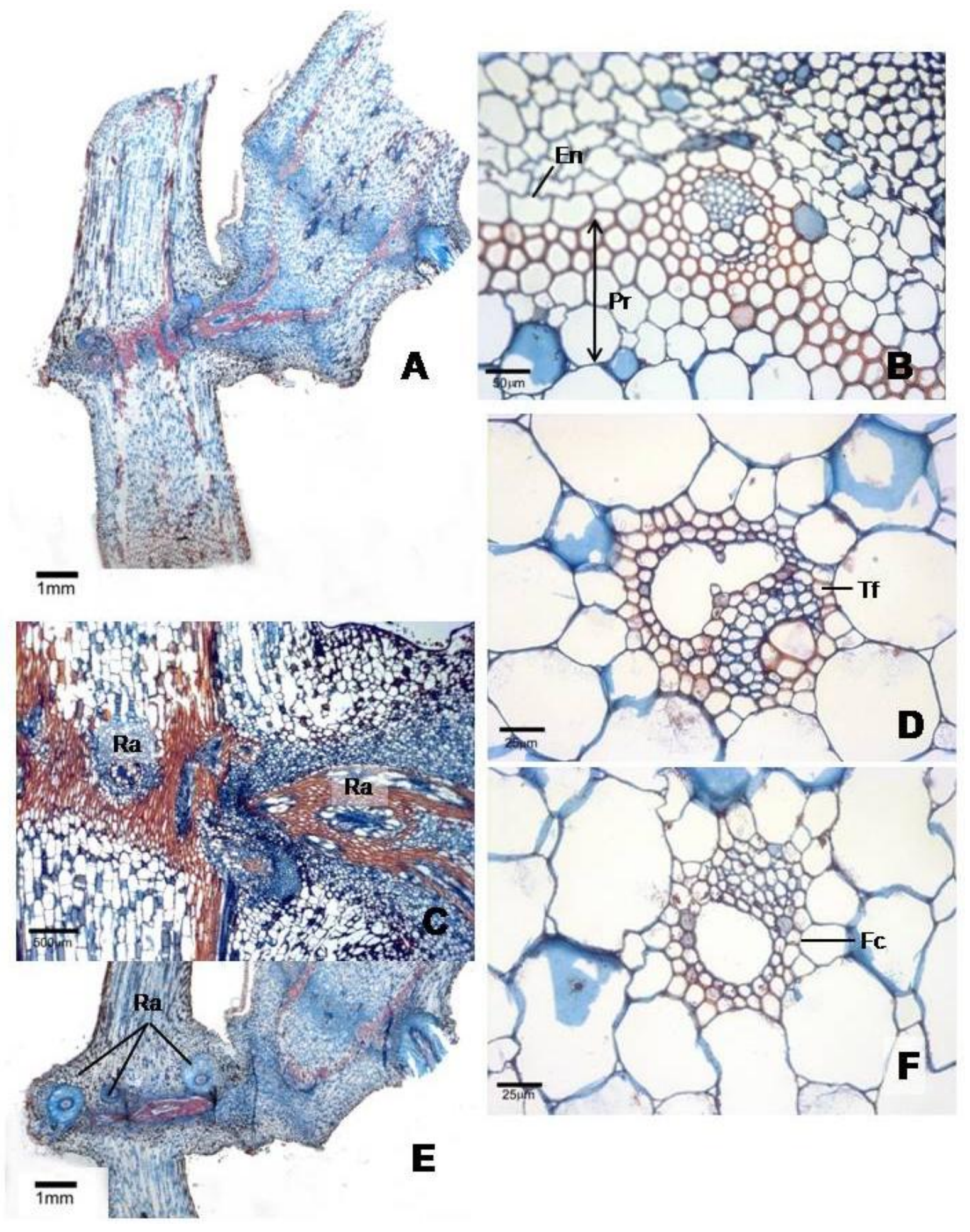

Fig. 2.17A-F -. Seções longitudinais (Fig. 2.17A, C e E) e transversais (Fig. 2.17A, B, D e F) de Commelina erecta. Fig 2.17A-C: observa-se a saída de um ramo na região do nó, que na Fig. 2.17E mostra três raízes adventícias $(\mathrm{Ra})$ em seção transversal. Fig 2.17B região pericíclica $(\mathrm{Pr})$ do caule com endoderme (En) e região pericíclica. Fig. 2.17D traço foliar (Tf) e Fig 2.17F feixe caulinar (Fc). 

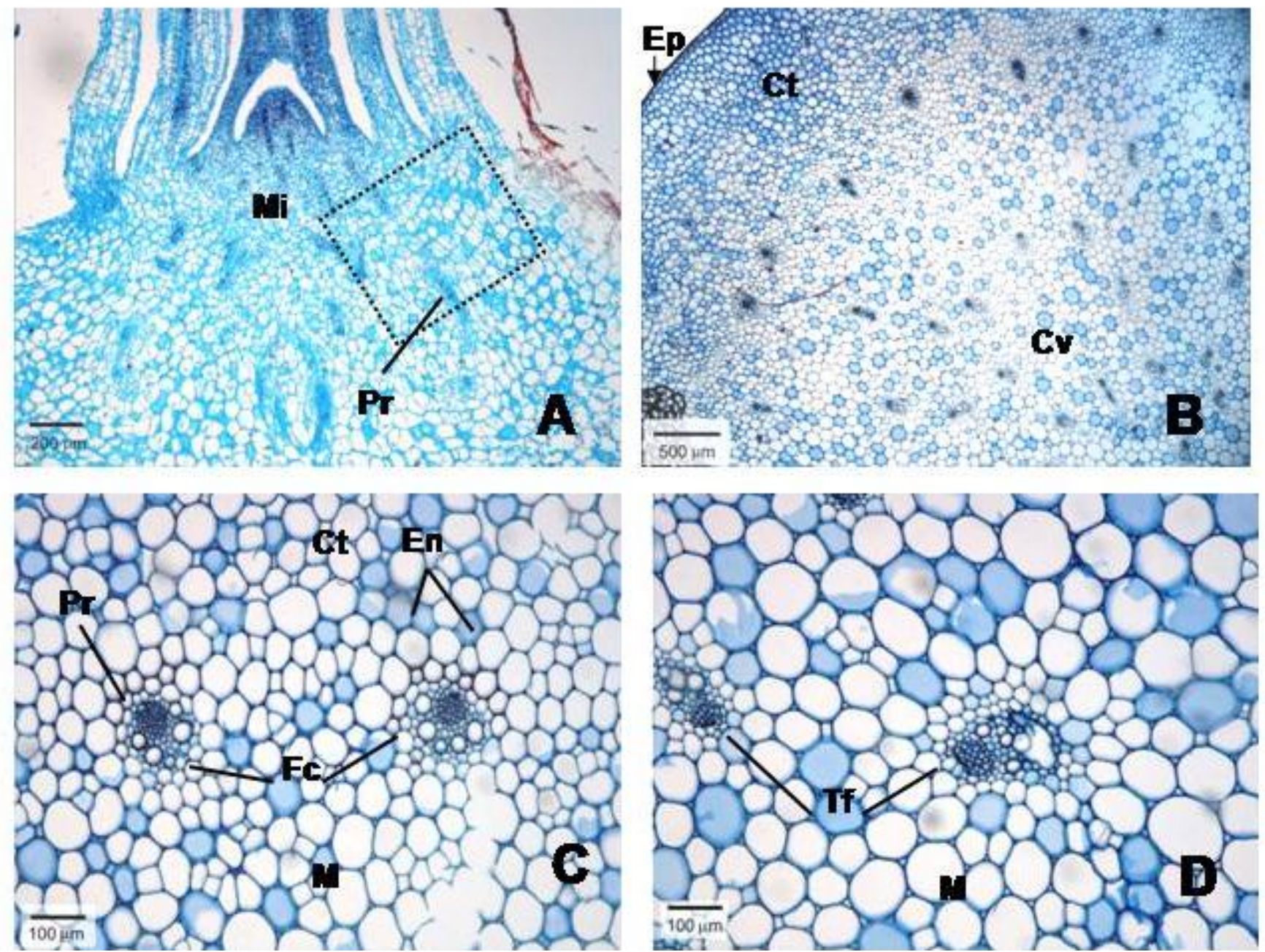

Fig. 2.18A-D. - Seções longitudinal do ápice (Fig. 2.18A) e transversais do caule aéreo próximo ao ápice (Fig. 2.18B-D) de Tradescantia spathacea . Na Fig 2.18A é possível observar, no destaque, o periciclo, e exatamente as resultantes da endoderme com atividade meristemática. Próximo ao ápice se distingui a endoderme (En) por ser a camada mais interna do córtex (Fig. 2.18B-C). Notam-se nas Fig. 2.18C-D feixes caulinares (Fc) e traços foliares (Tf). 

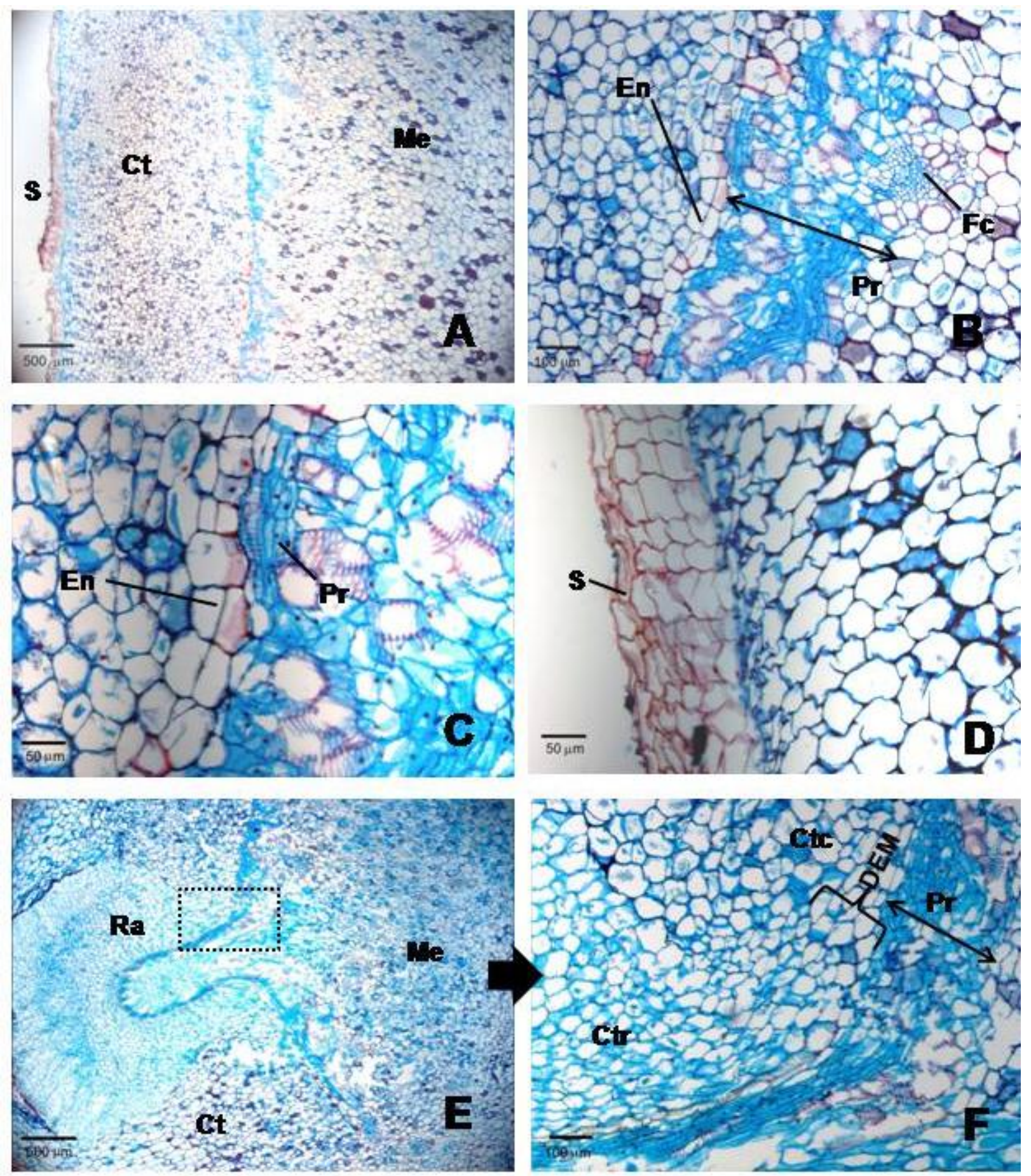

Fig. 2.19A-F - Seções transversais do caule de Tradescantia spathacea com tecidos mais diferenciados, notando-se a endoderme (En) (Fig. 2.19A-C) inclusive mostrando divisões (Fig. 2.19C), a região pericíclica (Pr) em grande atividade (Fig. 2.19A-C) e o súber estratificado (S) na Fig 2.19A e D. Nas Fig 2.19E-F observa-se no detalhe a saída de raiz adventícia (Ra) e a presença das derivadas da endoderme (DEM). Ctc: Córtex caulinar, Ctr; Córtex da raiz adventícia; Me- Medula. 


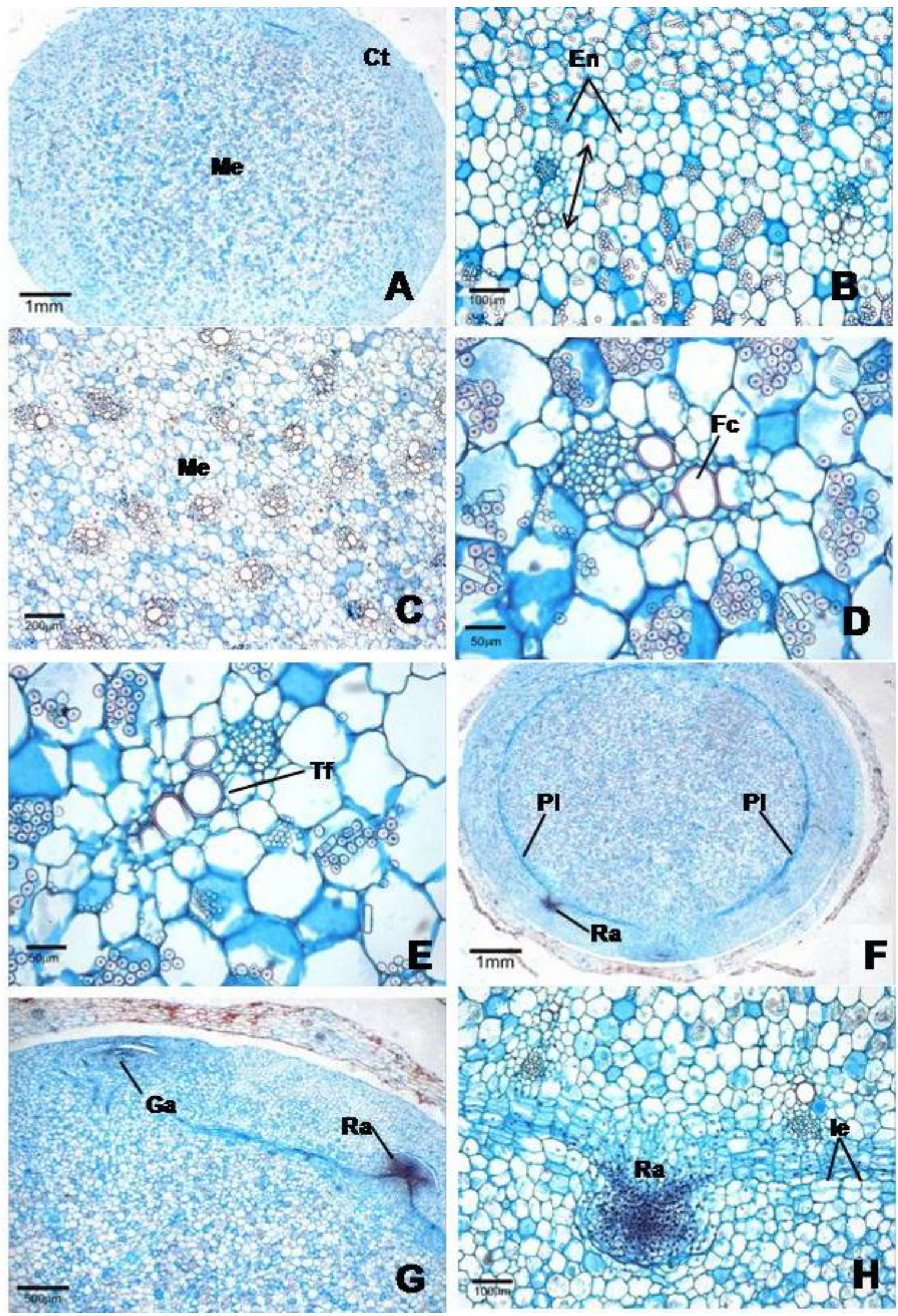

Fig. 2.20A-H. - Seções transversais do caule de Dichorisandra tyrsiflora em regiões mais próximas do ápice (Fig. 2.20A-D), nas quais, o limite do sistema vascular torna-se visível com o aparecimento do plexo periférico $(\mathrm{PI})$ (Fig 2.20E-H) na região pericíclica $(\mathrm{Pr})$ para a formação de uma raiz adventícia $(\mathrm{Ra})$. A endoderme (En) reconhecida por ser a camada mais interna do córtex (Fig 2.20A-B), nas Fig. 2.20H ainda aparece em divisão, podendo se distinguir a Inicial endodérmica (le). Me- Medula. 

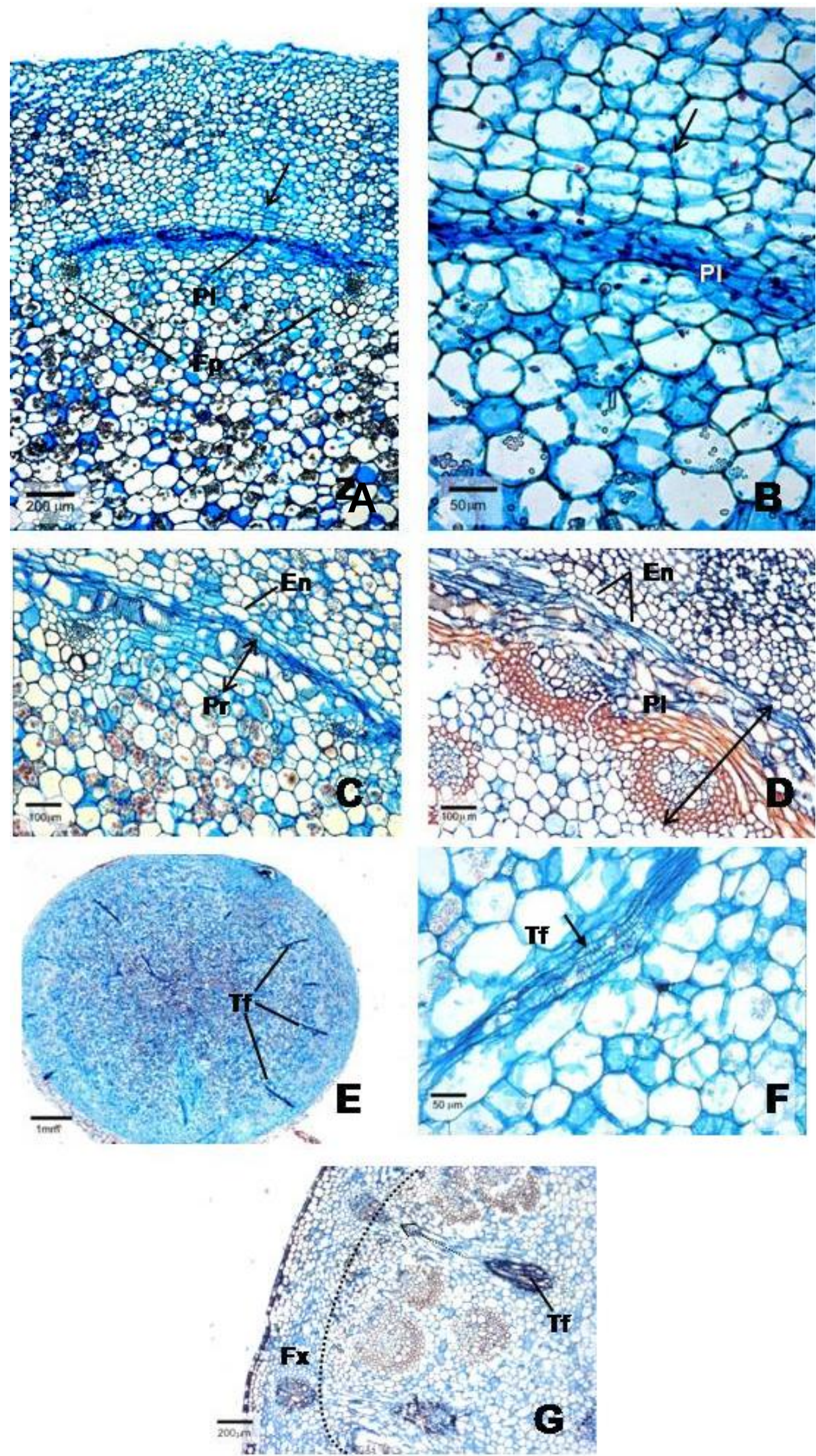

Fig. 2.21A-G - Seções transversais do caule Dichorisandra tyrsiflora notando-se além do plexo periférico (PI) na região pericíclica, as derivadas da endoderme meristemática (Fig. 2.21A e B). Na Fig. 2.21C e D distingui-se bem a endoderme (En), a região pericíclica $(\mathrm{Pr})$ e o plexo periférico $(\mathrm{PI})$ na região pericíclica. Observam-se os traços foliares (Tf) atravessando a região cortical (Fig. 2.21E), em detalhe, o traço foliar com protoxilema $(\mathrm{Px})$ e na Fig. 2.21G o traço foliar alcançando a bainha da folha tornando-se um feixe da folha $(F x)$. 

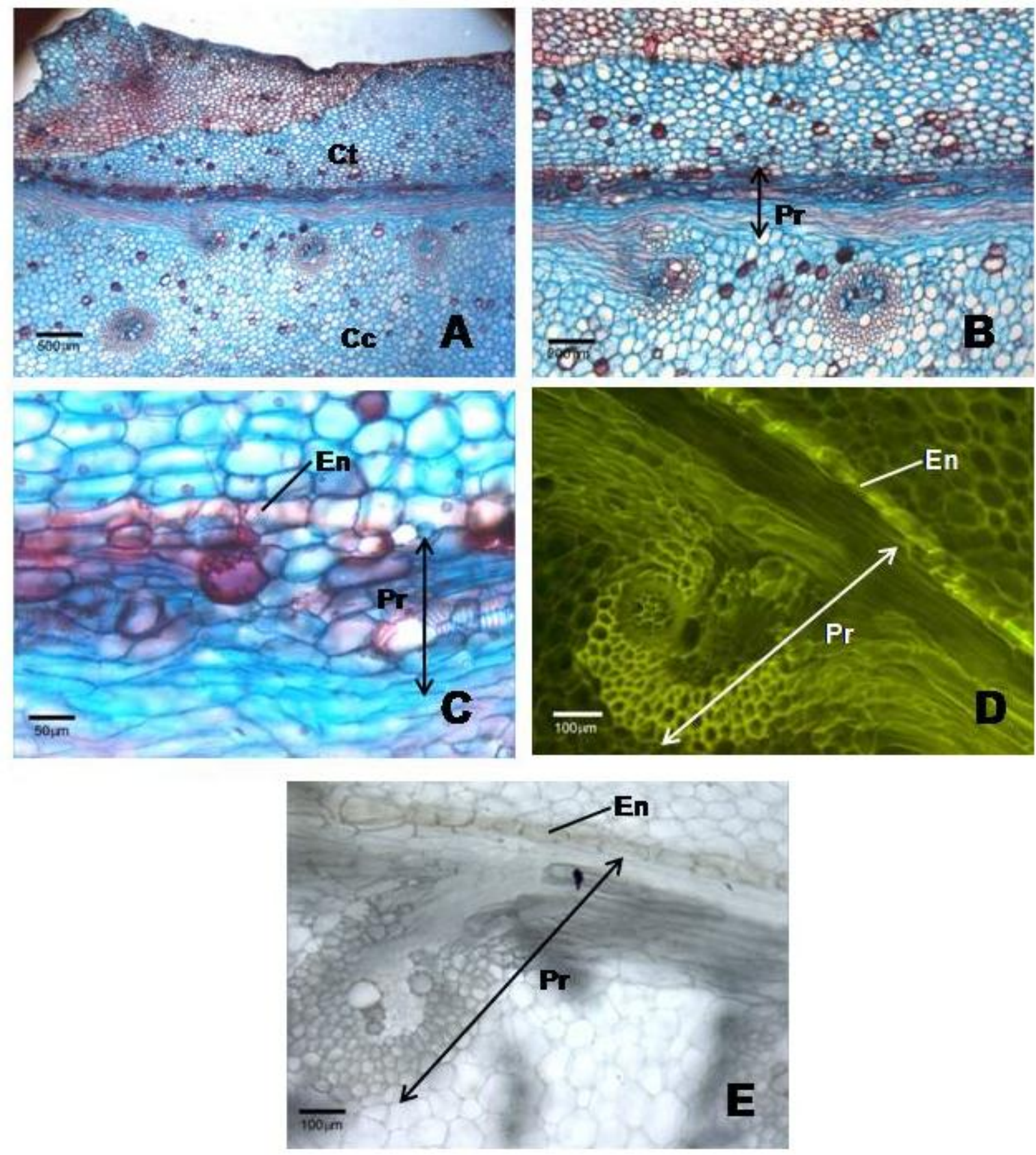

Fig. 2.22A-G. Seções transversais do rizoma de Dichorisandra tyrsiflora notando-se a o córtex (Ct) e o cilindro vascular (Cv) (Fig. 2.22A-B). Pode-se observar o plexo periférico $(\mathrm{PI})$, a região pericíclica $(\mathrm{Pr})$ e a endoderme com estrias de Caspary (Fig. 2.22C-E). Na Fig. 2.22D a estria é evidenciada por hemisulfato de berberina. 


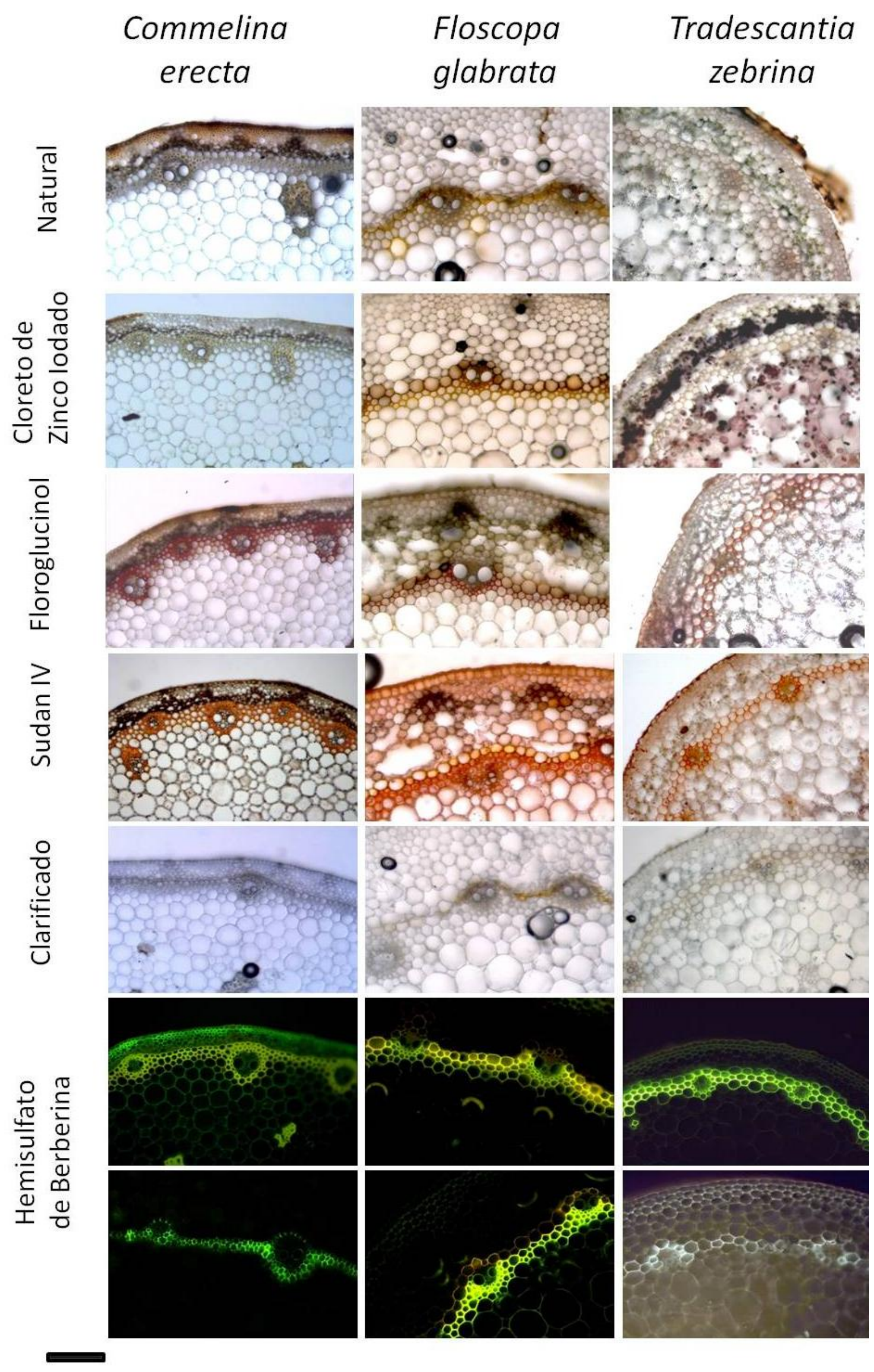

Fig. 2.23 - Testes microquímicos para visualização da endoderme, realizados para o entrenó de Commelina erecta, Floscopa glabrata e Tradescantia zebrina. Barra $=250 \mu \mathrm{m}$. 
Capítulo 3 


\section{ANATOMIA FOLIAR DE CINCO ESPÉCIES DE COMMELINACEAE (ENDODERME E PERICICLO)}

\section{Resumo}

Existem poucos relatos na literatura sobre a presença de endoderme e periciclo nas plantas vasculares. A maioria dos autores consideram os tecidos que envolvem os feixes vasculares das folhas como a bainha do feixe. O objetivo deste trabalho é mostrar que a bainha do feixe da folha é composta de endoderme e periciclo, bem como a continuidade destes tecidos entre o caule e a folha. Há uma perfeita continuidade entre os tecidos do caule e da folha quando se observa o traço indo em direção a folha. Nota-se também, que a endoderme que no caule envolve o cilindro vascular também envolve os feixes das folhas, constituindo assim, os monostelos. Não foi observada a presença de estria de Caspary na folha, foi observado somente 0 espessamento irregular da endoderme e do periciclo. Por se tratarem de monostelos, decidiu-se aceitar a denominação de "unidades vasculares" no lugar de "feixes", nas folhas.

\section{Abstract}

In specialized literature, reports on anatomy of presence of the endodermis and the pericycle in leaves of vascular plants are few in number. Most authors consider the tissues that involve the leaves bundles as sheath bundle. The aim of this work was to show the sheath bundle is composed by the endodermis and the pericycle, and investigate the continuity of tissues between stem and leaf in Monocotyledons. The results showed that there is a perfect continuity between the tissues of stem and leaf when the leaf trace is observed going in direction to the leaf. In addition, it was observed that the endodermis of stem involve not only the vascular cylinder but also the leaf bundles, that is, the monosteles. The presence of Caspary strip in the endodermis was not observed. It was decided to name the leaf bundle as "unity" instead of "bundle", as proposed for recently researches. 


\section{Introdução}

De acordo com algumas teorias evolutivas o sistema caulinar com folhas surgiu no Devoniano médio há mais de 387 milhões de anos atrás [5].

Atualmente, de um ponto de vista evolutivo, nas plantas (embriófitas) são encontrados dois tipos distintos de folhas: as microfilas e as megafilas. As microfilas são folhas que apresentam apenas um cordão vascular e são tipicamente associadas com caules protostélicos, características pertencentes às Licophytas. Já as megafilas são encontradas em todas as outras plantas vasculares e estão associadas a caules que possuem sifonostelelos e eustelos. Diferentemente das microfilas, a lâmina, da maioria das megafilas tem um sistema de nervuras ramificadas complexo $[5,17]$.

De acordo com diferentes teorias, microfilas podem ter surgido como protuberâncias laterais superficiais do caule e esta teoria é conhecida como teoria da enação. O provável surgimento dos megafilas é sugerido pela teoria telômica onde teria acontecido o achatamento de ramos caulinares laterais, resultando na expansão da lâmina da folha $[5,14,17]$.

Sendo os principais apêndices laterais do caule, as folhas se originam como protuberâncias no meristema apical caulinar e são conhecidas como primórdios foliares. A sua principal função é a fotossíntese (produção de compostos orgânicos), porém, a seleção natural reservou outras funções para as folhas, tais como: proteção de meristemas, atração de polinizadores (brácteas ou hipsofilos), suporte, estocagem e ainda associações interespecíficas com insetos (minas, galhas e etc) [11]. Todas estas funções 
lavaram as folhas a obter as grandes diversidades morfológicas que são encontradas hoje na natureza.

Nas monocotiledôneas são encontradas folhas de vários formatos, porém, é caráter diagnóstico para o grupo a venação paralela. A folha encontrada nas monocotiledôneas é denominada incompleta e invaginante, por apresentar em sua maioria apenas bainha e limbo, diferente das Eudicotiledôneas que apresentam, em geral, pecíolo e limbo, raramente bainha. Na família Commelinaceae, as folhas são simples, variando entre lanceoladas, ovadas e lineares e geralmente são suculentas [24]. Tomlinson [24] realizou uma grande revisão sobre a família, descrevendo a anatomia foliar de aproximadamente 99 espécies de maneira geral. Em sua descrição o autor encontra diversos caracteres diagnósticos para a família em tricomas e estômatos. Com relação à anatomia, o mesofilo e as nervuras são temas pouco explorados em comparação com a anatomia do tricomas e estômatos. Nenhum autor se refere à presença de endoderme na folha.

Para Menezes [12] há uma total identidade entre os tecidos do caule e da folha, onde o mesofilo da folha é o próprio córtex do caule, que está atuando como tecido fotossintetizante. Pita et al [16] demonstraram esta continuidade em Pteridófita. Menezes et al $[14,15]$ mostraram que a endoderme e o periciclo envolvem os traços foliares no caule e estes vão constituir as nervuras das folhas, envoltas pela endoderme e pelo periciclo, constituindo unidades vasculares, os monostelos. Esau [3] também admite que a bainha do feixe da folha é a endoderme, principalmente, com base nos trabalhos de Van Fleet [28]. 
Há muitos anos, diversos pesquisadores vêm mostrando que a bainha do feixe é a endoderme, especialmente em Gimnospermas [23]. Soar [21], em 1922, acompanhou o desenvolvimento da endoderme em folha de Abietinae, mostrando as diferentes fases de desenvolvimento desse tecido. Bond [1] ao encontrar endoderme em Piper, interpretou a endoderme como resultante da evolução de uma estrutura primitiva; em outras palavras, no mesmo período remoto da historia filogenética, a endoderme estaria associada com o sistema condutor de todos os órgãos da planta. Quando os grupos de plantas se tornaram adaptados a um habitat terrestre o valor funcional da endoderme no caule diminuiu, porém, permaneceu naquelas espécies que permaneceram aquáticas ou secundariamente regressaram àquele modo de vida [1]. Trapp [25] encontrou dois tipos de endoderme na folha de oito espécies de Plantago e também em Littorela lacustris. Segundo o mesmo autor, a endoderme encontrada ou era primária, com estria de Caspary, ou secundária, com lamela de suberina.

Para Van Fleet [27] as células parenquimáticas que envolvem o sistema vascular em folhas, que não apresentam características "endodérmicas", têm sido geralmente denominadas pelos anatomistas de parênquima da borda "border parenchyma", bainha do feixe parenquimatosa "parenchymatous bundle sheath", bainha do feixe "bundle sheath" ou bainha amilífera "starch sheath"; em ciperáceas e algums grupos de gramíneas é reconhecida como a bainha de Mestoma "mestome sheath". O autor comenta ainda, que sua proposta é mostrar que a borda ou bainha, através de testes histoquímicos, possui características de endoderme e que estas células podem se desenvolver em uma típica endoderme. 
Em sua revisão de 1961, Van Fleet [28] afirma que a bainha do feixe é a endoderme. Dickison [2] encontrou em Bonnetiaceae, o que ele chamou de especialmente interessante a presença, em alguns gêneros, dos feixes vasculares envolvidos por uma bainha composta de duas regiões concêntricas: a camada mais interna que consistia em múltiplas camadas de fibras e uma mais externa, especializada, a endoderme, compostas de células com paredes finas e com estrias de Caspary.

De acordo com Lersten [9] a endoderme ocorre de maneira variável entre os maiores taxas (Pteridófitas, Gimnospermas e Angiospermas). A endoderme é comumente igual em rizomas e folhas de Pteridófitas, com algumas exceções; ausente em caule de Gimnospermas, mas encontrada nas folhas de algumas coníferas e em caule da maioria das famílias de herbáceas, comum em pecíolos, no entanto, falta nas folhas. Para Wu [30], em Pinus bungeana a ligação dada entre a permeabilidade das células com estrias de Caspary e o papel das folhas sugere que a alta permeabilidade da membrana plasmática de células com estria de Caspary da folha facilitaria o transporte de assimilados e de água para o mesofilo e para o tecido vascular e vice-versa.

Menezes [12], estudando a saída dos traços foliares, demonstrou que o traço ao atravessar do cilindro vascular para o córtex do caule sai envolvido pela endoderme que constitui a bainha do feixe da folha. Posteriormente, Menezes et al [14] demonstraram que a endoderme está sempre presente nas folhas e, em trabalho posterior, Menezes et al [15] não só demonstraram a presença da endoderme, mas também que ela pode apresentar atividade meristemática originando parte do mesofilo em Echinodorus paniculatus. 
Menezes et al [14] propuseram que se denomine o chamado feixe vascular da folha de unidade vascular, pois cada estrutura é formada por xilema primário, floema primário e periciclo, envolvidos por endoderme. Propuseram as autoras denominarem de unidades vasculares ou monostelos. 


\section{Objetivos}

O objetivo deste trabalho é demonstrar que a bainha dos feixes da folha destas espécies é a endoderme e, internamente a ela, encontra-se o periciclo, demonstrando se tratar de unidades vasculares ou monostelos, e também, a perfeita continuidade dos tecidos entre caule e folha. 


\section{Materiais e Métodos}

O estudo das folhas foi realizado a partir de cortes histológicos transversais obtidos à mão, utilizando lâmina de barbear e através de micrótomo rotativo.

Os cortes à mão foram corados com azul de astra e safranina ou ainda safrablau (Bukatsch 1972 apud Krauss e Arduim [8] ) e, posteriormente, montados em lâminas histológicas com glicerina líquida 50\%.

Para a obtenção dos cortes em micrótomo rotativo, o material foi incluído em parafina segundo a metodologia descrita por Sass [19], Johansen [7] ou Kraus e Arduim [8] ou em historresina. Para inclusão em parafina, o material foi previamente desidratado em série butanólica terciária [7, 19]. Nos cortes em parafina foram testadas as colorações azul de astra e safranina (Bukatsch 1972 apud Kraus \& Arduim [8]). A montagem das lâminas histológicas foi realizada com bálsamo do Canadá.

Os testes microquímicos foram realizados empregando-se sudan IV para substâncias lipídicas, como suberina e cutina, [4] e floroglucinol acidificado para ligninas [7]. Para lipídios, o material controle foi tratado previamente com clorofórmio e metanol segundo Herr e Peterson [6]. Para visualização das estrias de Caspary e estruturas suberificadas utilizou-se também a coloração fluorescente hemisulafato de berberina, segundo Lux e Luxová [10]. 


\section{Resultados}

Commelina erecta, Dichorisandra tyrsiflora, Floscopa glabrata, Tradescantia spathacea e T. zebrina apresentam folhas simples, glabras e com venação paralelódroma.

Em corte transversal do caule (Fig. 3.1A-D) pode-se observar a continuidade entre os tecidos do caule e da folha. O traço foliar que sai do complexo vascular, localizado no centro do cilindro vascular, ao nível do nó, sai perpendicularmente ao eixo do órgão e penetra na bainha da folha. Na Fig. 3.1D nota-se que ao ultrapassar a camada limite entre o córtex e o cilindro central (endoderme e periciclo) o traço, formado por xilema e floema primário, passa a ser envolvido pelo periciclo e pela endoderme, tornando-se um monostelo. Ainda nas mesmas figuras, principalmente na Fig 3.1A é perfeitamente perceptível que os tecidos da bainha da folha são os mesmos do caule.

No limbo da folha, em seções transversais, das espécies $C$. erecta, $F$. glabrata e T. zebrina a epiderme é unisseriada, constituída por células altas com paredes não espessadas e isodiamétricas (Fig 3.2A, B, E, F, I e J). As espécies $D$. tyrsiflora e T. spathacea apresentam as células epidérmicas bem menores (Fig. 3.2C, D, G, H). As seções transversais ainda mostram estômatos localizados no nível das demais células epidérmicas, distribuídos em ambas as faces em $F$. glabrata (folhas anfiestomáticas); em $C$. erecta, $D$. tyrsiflora, $T$. spathacea e $T$. zebrina foram encontrados somente estômatos na face abaxial. Nas Fig. 3.2C-J observa-se a presença de uma hipoderme que na espécie $T$. spathacea é constituída de duas camadas de células bem maiores que as epidérmicas e na espécie $T$. zebrina as células são altas e com apenas uma camada de células que 
ocupam a metade da espessura da lâmina foliar, o que oferece grande suculência para as folhas. O mesofilo é dorsiventral com parênquima paliçádico e lacunoso, porém, em T. zebrina é isomorfo e ocupa área bem reduzida (Fig. 3.2I-J), com idioblastos contendo ráfides ou cristais romboédricos (dados não ilustrados).

As unidades vasculares estão distribuídas na região mediana do mesofilo. Todas as unidades vasculares apresentam uma endoderme bem distinta, geralmente com espessamento irregular; não foram observadas estrias de Caspary (Fig. 3.3A-H, 3.4A-F). O periciclo (bainha interna do feixe) é constituído por uma ou duas camadas de células que geralmente estão lignificadas irregularmente (Fig. 3.3A-H e 3.4A-F). As unidades vasculares são colaterais com maior quantidade de elementos floemáticos quando comparados ao xilema.

A endoderme pode se apresentar parenquimática, pode se apresentar com células parenquimáticas e células com paredes espessadas ou pode apresentar todas as células espessadas, com exceção as dos flancos das unidades vasculares. Em $C$. erecta observam-se células endodérmicas espessadas e não espessadas (Fig. 3.3A-D), melhor observado na Fig. 3.3D. Observa-se também, a saída de uma ramificação da nervura (Fig. 3.3C) também envolvida pela endoderme espessada.

Em F. glabrata a endoderme é especialmente parenquimática (Fig. 3.3E-H) podendo apresentar com menor evidência, células espessadas. Em T. spathacea há, também, predominância de células parenquimáticas na endoderme (Fig. 3.4A-B), o mesmo foi observado em T. zebrina (Fig. 3.4C), sendo que na Fig. 3.4A podem ser observadas células com paredes especialmente espessadas. Em D. tyrsiflora (Fig. 3.4D-F), na nervura mediana, a endoderme apresenta-se espessada na face adaxial e parenquimática na abaxial. Nas unidades vasculares subseqüentes, observa-se espessamento nas células em toda volta (Fig. 3.4E, F). Por mais espessadas que 
estejam as células da endoderme, nos flancos das unidades vasculares as células são, em geral, parenquimáticas (Fig. 3.3A-D, Fig. 3.3G-H, Fig. 3.4A, B, E e F). 


\section{Discussão}

A continuidade de tecidos primários entre o caule e a folha observados nestas espécies foi encontrada também por Menezes em 1971 [12], em Velloziaceae. Neste trabalho a autora observou que próximo ao ápice caulinar, o córtex do caule era contínuo com o mesofilo das folhas e que os traços foliares que saíam do caule constituíam os feixes foliares. Foi também verificada essa continuidade em Melastomataceae [14] e em Pteridófitas [16].

A epiderme de três espécies é constituída por células altas que desempenham, também, a função de armazenamento de água. Da mesma maneira, a hipoderme encontrada apenas na região da nervura mediana em Commelina erecta, Dichorisandra tyrsiflora e Floscopa glabrata e encontrada em todo o limbo de T. spathacea e T. zebrina também armazenam, proporcionalmente, grandes quantidades de água. Nessas espécies nota-se que o limbo da folha é constituído principalmente pelas camadas da epiderme e hipoderme e pouco representado pelo paliçádico e pelo lacunoso. Essas características tornam as folhas destas espécies suculentas [22]. O clorênquima dorsiventral constitui pequena parte do limbo da folha nas espécies com cristais e taninos sempre localizados no paliçádico [24]

Neste trabalho optou-se por denominar de unidades vasculares os feixes por concordar com a proposta de Menezes et al [15], porque, realmente, cada unidade é um monostelo, ou seja, a menor porção do sistema vascular - xilema e floema primários envolvidos pelo periciclo e internos à endoderme.

As unidades vasculares, em Monocotiledôneas, estão sempre envoltas pela endoderme e pelo periciclo, ambos os tecidos, constituindo a bainha do feixe. Para Tomlinson [24], as folhas de Commelinaceae freqüentemente apresentam a bainha 
do feixe completa, podendo apresentar um espessamento de parede na porção inferior e superior ou apenas na inferior, mas não se refere aos tecidos endoderme e periciclo. As unidades vasculares diferem de tamanho nas diferentes espécies de feixes grandes até medianos em $C$. erecta, $D$. tyrsiflora e em $F$. glabrata e menores, em relação as anteriores, em $T$. spathacea e $T$. zebrina.

Muitas espécies de Monocotiledôneas apresentam estrias de Caspary na endoderme da unidade vascular como em Zea mays, Nymphoydes indica e Frimbritylis annua [14]; no entanto, em gêneros de Gimnospermas, como Pinus, a endoderme também possui estrias [30]. Em Pteridófitas (Filicines), a endoderme com estria de Caspary nas células representa uma situação bem generalizada [14]. Outra característica marcante da endoderme, em folhas, é a presença de amido (bainha amilífera) fato também observado em Tumbergia grandiflora [14]. Porém, não foi observada a presença de estrias de Caspary em nenhuma das espécies estudadas e nem amido na endoderme destas espécies, (apenas cloroplastos em C. erecta) fato já mencionado em Lagenocarpus bracteosus [20]. Vieira et al [29] descrevem que em Poaceae a bainha externa do feixe é a endoderme e a bainha interna é o periciclo. Van Fleet [26] declara que a camada mais interna do mesofilo é, sempre, a endoderme com estria, suberina, cristais, ou nenhuma característica anatômica diferente, desde que seja a camada mais interna do mesofilo. Outros autores como Trapp [25], Soar [21] e Lersten [9] encontraram endoderme nas folhas de outros taxa, inclusive em Angiospermas basais.

Outra característica importante da endoderme é a sua atividade meristemática na folha [15], fato de grande relevância também não encontrado nas espécies do presente estudo. 
Apesar das espécies, aqui estudadas, não apresentarem características como a presença de amido ou a presença de estrias, através da reação com cloreto de zinco iodado e com sudan IV, verificou-se a presença de suberina, pelas colorações semelhantes à adquirida pela cutina da epiderme. No entanto, não foi possível demonstrar com fotos. A endoderme nestas espécies se encontra completamente lignificada, parcialmente lignificada ou sem qualquer lignificação. Em Cyperaceae e alguns grupos de gramíneas apresentam a endoderme espessada, denominada de bainha de mestoma [18].

Menezes [13] descreveu a bainha mestomática em Barbacenioideae. Talvez se pudesse chamar de bainha de mestoma também em espécies de Commelinaceae, mas não há uma continuidade entre as células espessadas, pois, nos flancos da unidades vasculares, há de uma a três células não espessadas. Quando há uma célula, ela é bem maior que as demais.

Desta maneira, com os resultados obtidos aqui, corroboram-se as pesquisas de Menezes e seus colaboradores [14] que afirmam que todos os tecidos primários que estão na raiz, estão também no caule e na folha e também, confirmando a presença dos tecidos primários endoderme e periciclo na folha. 


\section{Referências}

[1] BOND, G. 1931. The stem endodermis in the genus Piper. Transactions of the Royal Society of Edinburgh, v.56, p.695-724.

[2] DICKISON, W. C.; WEITZMAN, A. L. 1996. Comparative anatomy of the young stem, node, and leaf of Bonnetiaceae, including observations on a foliar endodermis. American Journal of Botany, v.83, n.4, p.405-418.

[3] ESAU, K., 1965. Plant anatomy 2ed: New York : Wiley. 767 p.

[4] GERLACH, P. B., 1984. Botanische Mikrotechinique. Stuttgart: Georg Thieme Verlag. $311 \mathrm{p}$.

[5] GIFFORD, E. M.; FOSTER, A. S., 1989. Morphology and evolution of vascular plants. 3 ed. New York: WH Freeman.p.

[6] HERR, D. G.; PETERSON, R. L. 1996. Morphology, anatomy and histochemistry of Fagus grandifolia Ehm. (North American Beech) ectomycorrhizas. . Botanica Acta, v.109, p.64-71

[7] JOHANSEN, D. A., 1940. Plant microtechnique. New York: McGraw-Hill.p.

[8] KRAUSS, J. E.; ARDUIN, M., 1997 Manual Básico de Métodos em Anatomia Vegetal. Rio de Janeiro: EDUR (Ed. Universidade Rural). 198 p.

[9] LERSTEN, N. R. 1997. Occurrence of endodermis with a casparian strip in stem and leaf.(Interpreting Botanical Progress). The Botanical Review, v.63, n.3, p.265268.

[10] LUX, A.; LUXOVÁ, M. 2003. Growth and Differentiation of Root Endodermis in Primula acaulis Jacq. Biologia Plantarum, v.47, n.1, p.91-97.

[11] MAUSETH, J. D., 1988. Plant Anatomy. The Bejamin, Cummings Publishing Company Inc. 560 p.

[12] MENEZES, N. L. 1971. Traqueídes de transfusão no gênero Vellozia Vand. Ciência e Cultura, v.23, p.389-409. 
[13] MENEZES, N. L. 1975. Presença de traqueídes de transfusão e bainha mestomática em Barbacenioideae (Velloziaceae). Boletim de Botânica da Universidade de São Paulo, v.3, n.8, p.29-60.

[14] MENEZES, N. L.; SILVA, D. C.; MELO-DE-PINNA, G. F. A., 2003. Folha. In: APPEZZATO-DE-GLÓRIA, B.; CARMELO-GUERREIRO, S. M. Anatomia Vegetal. Viçosa: UFV. p. 303-325.

[15] MENEZES, N. L. D.; SILVA, D. C.; ARRUDA, R. C. O.; MELO-DE-PINNA, G. F.; CARDOSO, V. A.; CASTRO, N. M.; SCATENA, V. L.; SCREMIN-DIAS, E. 2005. Meristematic activity of the Endodermis and the Pericycle in the primary thickening in monocotyledons: considerations on the "PTM". Anais da Academia Brasileira de Ciências, v.77, p.259-274.

[16] PITA, P. B.; DE MENEZES, N. L.; PRADO, J. 2006. Morfologia externa e interna das folhas vegetativas, esporofilos e esporângios de espécies de Huperzia Bernh.(Lycopodiaceae-Pteridophyta) do Brasil. Revista Brasileira de Botânica, v.29, n.1, p.115-131.

[17] RAVEN, P. H.; EVERT, R. F.; EICHHORN, S. E., 2001. Plantas vasculares sem sementes. In: RAVEN, P. H.; EVERT, R. F.; EICHHORN, S. E. Biologia Vegetal. Rio de Janeiro: Guanabara Koogan. cap.19. p. 408-447.

[18] RODRIGUES, A. C.; ESTELITA, M. E. M. 2003. Origin and structure of the Kranz tissue in bracts of Cyperus giganteus Vahl (Cyperaceae). Revista Brasileira de Botânica, v.26, p.445-452.

[19] SASS, J. E., 1951. Botanical Microtechnique lowa State College Press. 228 p.

[20] SILVA, D. C. Anatomia dos órgãos vegetativos de Lagenocarpus (Cyperaceae). 2000, Tese de doutorado, Universidade de São Paulo, São Paulo.

[21] SOAR, I. 1922. The structure and function of the endodermis in leaves of the Abietineae. New Phytologist, v.21, n.5, p.269-292.

[22] SOLOREDER, H.; MEYER, F. J. 1929. Commelinaceae in Systematische Anatomie der Monokotyledonen. Heft, v.IV, p.129-55.

[23] TAKEDA, H. 1913. A Theory of 'Transfusion-tissue'. Ann Bot, v.os-27, n.2, p.359-363. 
[24] TOMLINSON, P. B., 1969. III - Commelinales-Zingiberales. In Anatomy of the Monocotyledons (C.R. Metcalfe, ed.). Oxford, : Clarendon Press 446 p.

[25] TRAPP, G. A. 1933. A study in the foliar endodermis of the Plantaginaceae. Transactions of the Royal Society of Edinburgh, v.57, n.II, p.523-546.

[26] VAN FLEET, D. S. 1942. The development and distribution of the endodermis and an associated oxidase system in monocotyledonous plants. American Journal of Botany, v.29, n.1, p.1-15.

[27] VAN FLEET, D. S. 1950. The cell forms, and their common substance reactions, in the parenchyma-vascular boundary. Bulletin of the Torrey Botanical Club, v.77, n.5, p.340-353.

[28] VAN FLEET, D. S. 1961. Histochemistry and function of the endodermis. The Botanical Review, v.27, n.2, p.165-220.

[29] VIEIRA, R. C.; GOMES, D. M. S.; SARAHYBA, L. S.; ARRUDA, R. C. O. 2002. Leaf anatomy of three herbaceous bamboo species. Brazilian Journal of Biology, v.62, p.907-922.

[30] WU, X.; LIN, J.; LIN, Q.; WANG, J.; SCHREIBER, L. 2005. Casparian strips in needles are more solute permeable than endodermal transport barriers in roots of Pinus bungeana. Plant Cell Physiology, v.46, n.11, p.1799-1808. 

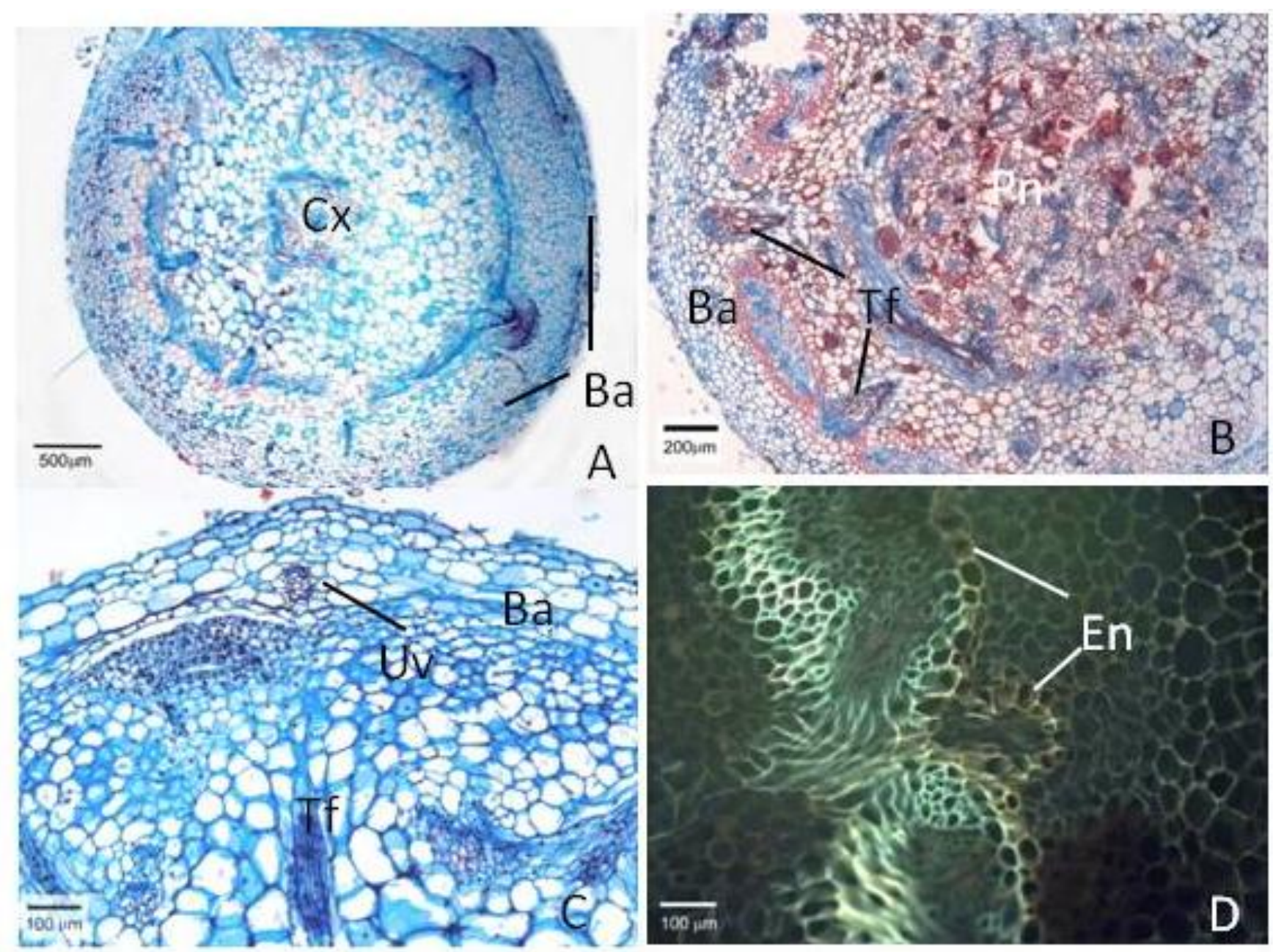

A
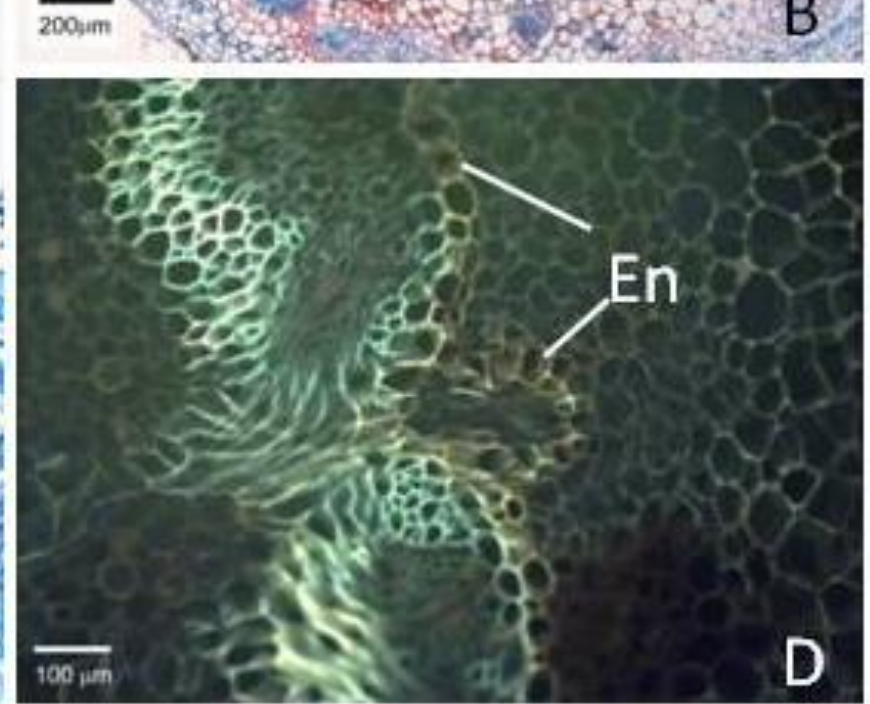

Fig. 3.1A-D - Secões tranversais dos caules (região nodal) de Tradescantia zebrina (Fig. 3.1A-C), Commelina erecta Fig. 3.1B) e Floscopa glabrata (Fig 3.1D), sendo esta sob fluorescência. Nota-se a continuidade dos tecidos entre o caule e a folha, na Fig 3.1A -C nota-se os complexos vasculares (Cx) e os traços foliares indo em direção à bainha da folha (Ba). Fig 3.1D: pode- se observar a endoderme (En) envolvendo o traço foliar. Uv- Unidade vascular. 

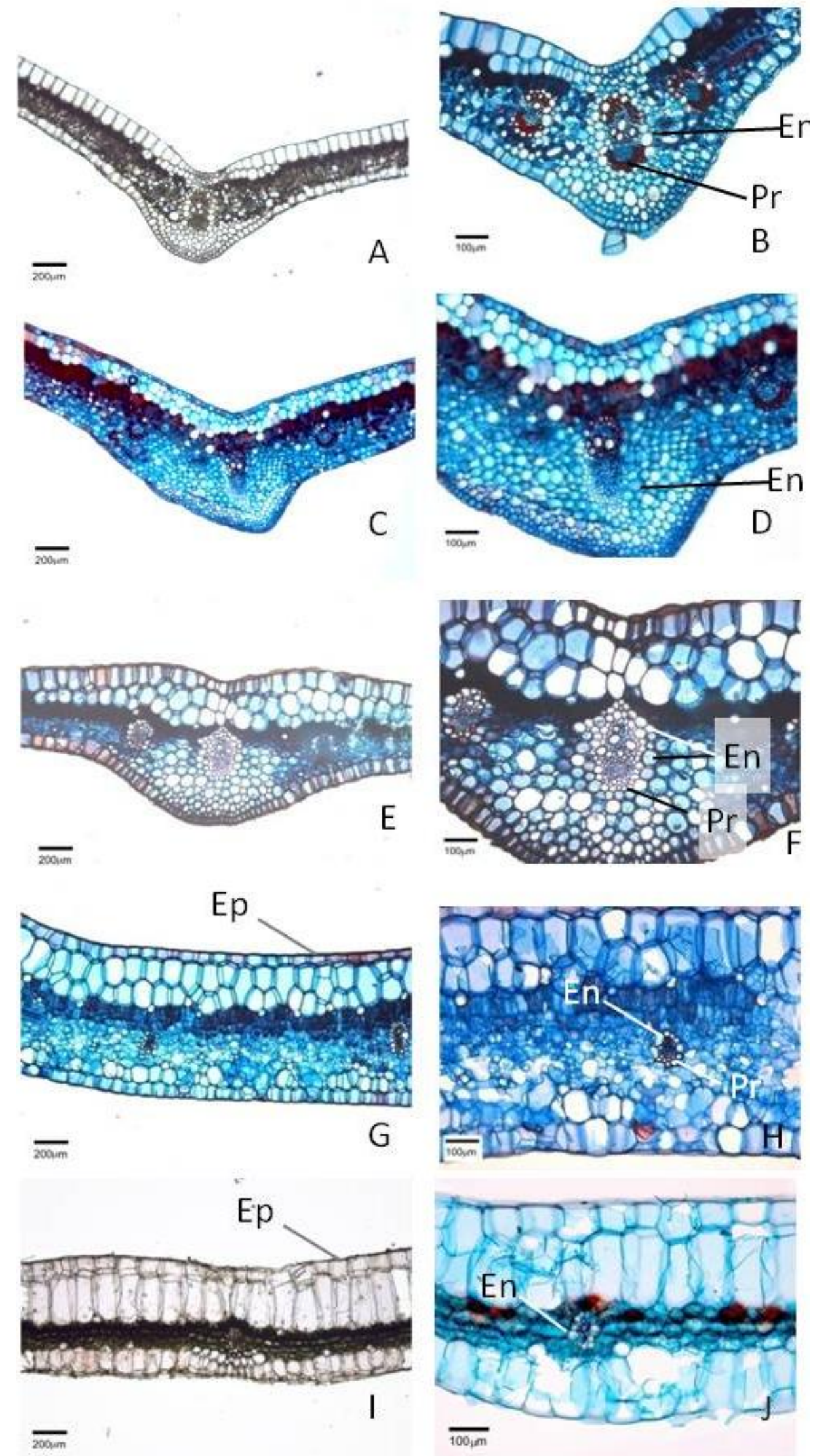

Fig. 3.2A-J - Seções transversais da folhas de Commelina erecta (Fig. 3.2A-B), Dichorisandra tyrsiflora (Fig. 3.2C-D), Floscopa glabrata (Fig. 3.2E-F), Tradescantia spathacea (Fig. 3.2G-H) e Tradescantia zebrina(Fig. 3.2I-J). En- Endoderme. 

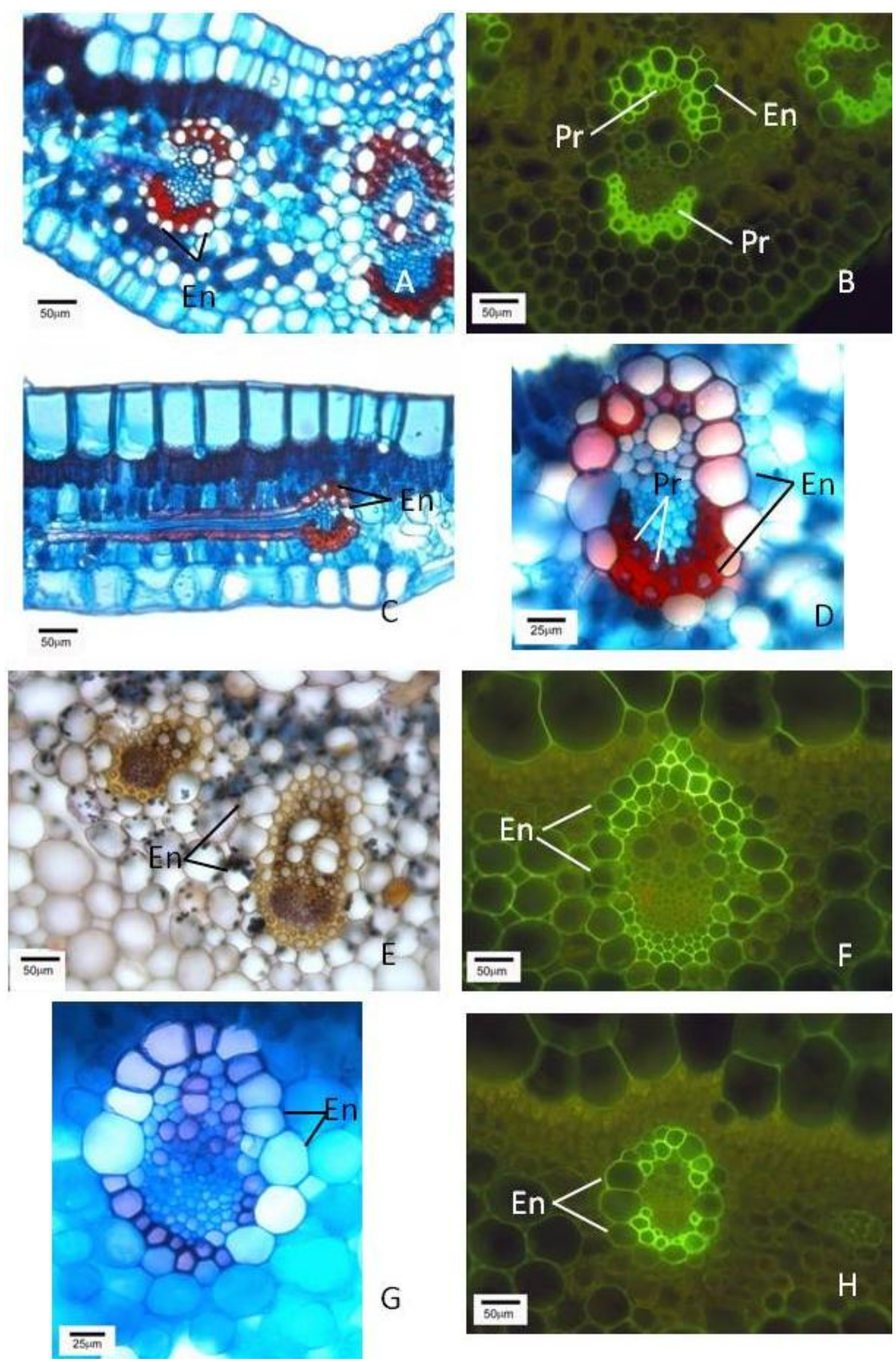

Fig. 3.3A-J - Aspecto anatômico geral da folhas de Commelina erecta (Fig. 3.3A-D), Floscopa glabrata (Fig. 3.3E-H), notando-se as unidades vasculares envolvidas pela endoderme (En) e periciclo ( $\mathrm{Pr})$. 

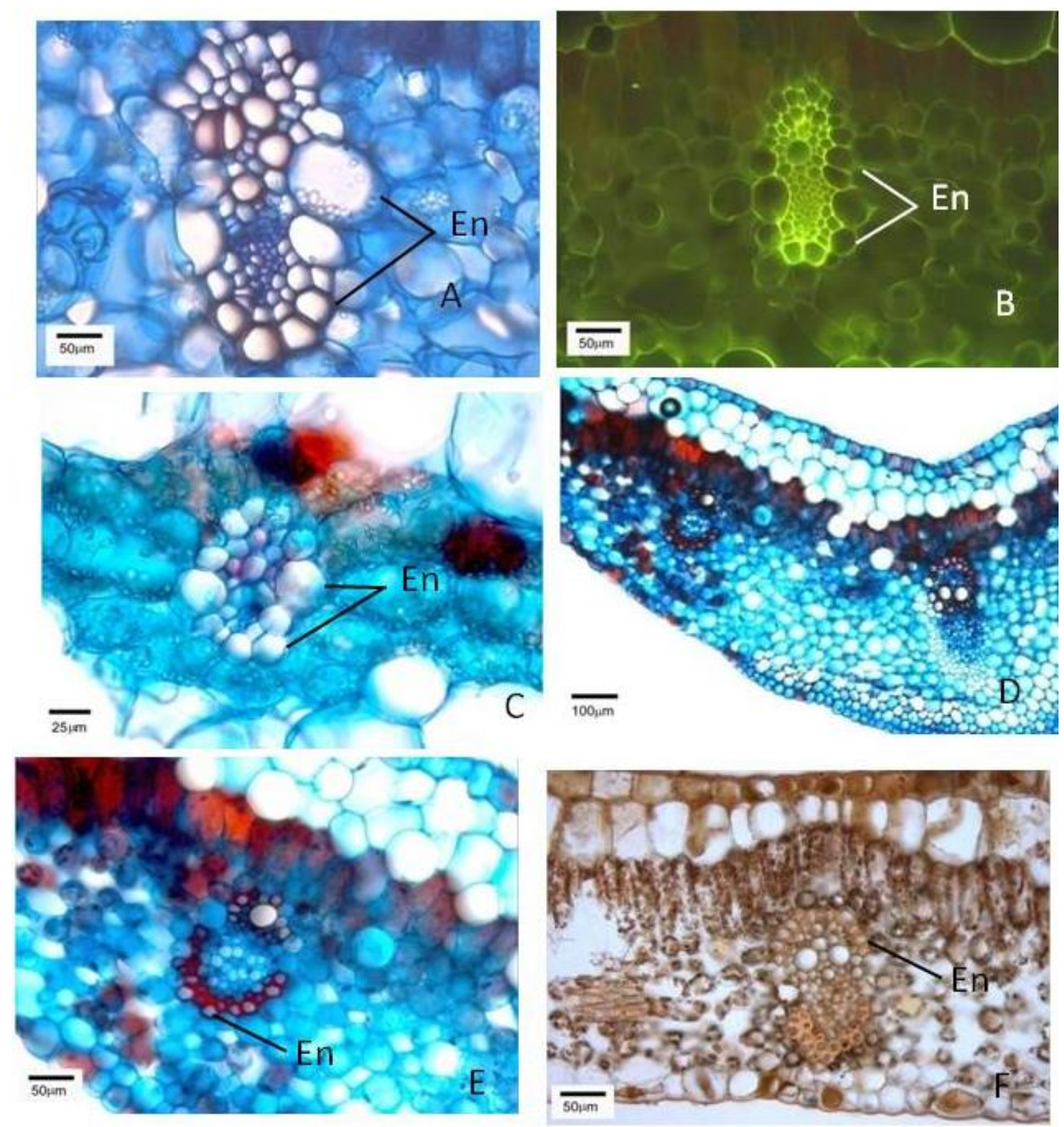

Fig. 3.4A-F - Seções transversais das folhas de Tradescantia spathacea(Fig. 3.4A-B); Tradescantia zebrina (Fig. 3.4C) e Dichorisandra tyrsiflora (Fig. 3.4D-F) notando-se as unidades vaculares envolvidas pela endoderme (En) e periciclo $(\mathrm{Pr})$. 
Capítulo 4 


\section{MORFOLOGIA E ANATOMIA DE MINAS FOLIARES EM COMMELINA DIFFUSA WILLD. EX. KUNTH E FLOSCOPA GLABRATA (KUNTH) HASSK. (COMMELINACEAE).}

\section{$\underline{\text { Resumo }}$}

Há poucos relatos na literatura sobre anatomia de plantas parasitadas por agentes minadores, os quais promovem escavações ou caminhos através do consumo dos tecidos internos das plantas por larvas de diversos insetos. A proposta deste trabalho foi analisar anatomicamente a ocorrência de minas foliares em Commelina diffusa e Floscopa glabrata causadas por espécies de larvas endofitófagas de dípteros, pertencentes a duas famílias: Agromyzidae e Chironomidae. Em Commelina diffusa foram encontradas larvas da família Agromyzidae e em Floscopa glabrata observaram três exuvias cefálicas de Chironomidae. Os dados anatômicos revelaram que os minadores consumiram apenas os tecidos parenquimáticos do mesofilo, formando minas lineares. Além disso, notou-se que a epiderme e os tecidos vasculares de porte médio foram mantidos intactos em ambas as espécies, não apresentando alterações estruturais, como a neoformação de tecidos.

\section{Abstract}

In specialized literature, reports on anatomy of miners in host plants are few in number. These agents trigger excavations, or paths, by consumption of plant inner tissues by larvae of several insects. The aim of this work was to investigate leaf miner occurrence in Commelina diffusa and Floscopa glabrata using anatomical techniques. In this case, it was discovered that members of Agromyzidae and Chironomidae families, which are Diptera endophytophagous larvae types, were responsible for the tunnels. Moreover, in Commelina diffusa was found Agromyzidae larvae while in Floscopa glabrata three Chironomidae cephalic exuviae were found. The miners, as shown by anatomical studies, used only parenchymatic tissues of mesophyll for their feeding, causing the formation of linear miners. In addition, the epidermis and the middle-sized vessel bundles, in both species, were kept intact, showing no structural modification, like neoformation of tissues. 


\section{Introdução}

A associação minador-planta pode ter surgido há 275 milhões de anos sendo, provavelmente, uma interação benéfica ao hospedeiro, pois, este encontra abrigo e alimento durante a fase larval de seu ciclo [13].

Existem aproximadamente 10.000 espécies descritas de minadores foliares que ocorrem dentro de 51 famílias de insetos holometábolos, isto é, metamorfose completa. Essas ordens incluem Coleoptera, Diptera, Lepidoptera e Hymenoptera [4, $5,7,8,16]$.

Das espécies vegetais atuais são relatadas minas em um grande número de famílias, tais como: Amaranthaceae, Asteraceae, Boraginaceae, Chenopodiaceae, Commelinaceae, Convolvulaceae, Dipsacaceae, Lamiaceae, Mytaceae, Poaceae, Rubiaceae e Rutaceae [7, 15, 19]. Em trabalho recente, Santos et al. [19] registraram a ocorrência de dípteros minadores em seis famílias de angiospermas; dentre elas, apenas uma espécie de Commelinaceae (Commelina diffusa Burn.), na qual foram encontradas 81 larvas e 43 pupas de Liriomyza commelinae (Agromyzidae). No entanto, ressalta-se que não foi objetivo dos autores descrever anatomicamente as minas, aspecto que não foi registrado até o momento em representantes de Commelinaceae. 


\section{Objetivos}

Este trabalho teve como objetivo registrar a ocorrência de minas foliares causadas por ação de dípteros, apresentando uma descrição anatômica em duas espécies de Commelinaceae ocorrentes na Serra do Cipó (MG). 


\section{Materiais e Métodos}

Folhas não minadas e minadas de Commelina difusa Willd. ex Kunth e Floscopa glabrata (Kunth) Hassk. foram coletadas de indivíduos localizados nas margens do Córrego Braúna, onde ocorrem afloramentos de mata ciliar na Serra do Cipó (19 18' 03,9”S, 43 36' 04,1'W; 1046 m), Minas Gerais, Brasil.

Para análise anatômica, folhas minadas e não minadas foram fixadas em FAA 50 (formaldeído, ácido acético e etanol 50\%, 1:1:18 v/v) por 48 horas Johansen [10] e desidratadas em série etanol/álcool butílico terciário (50-100\%), sendo posteriormente incluídas em parafina, seguindo metodologia descrita por Ruzin [17]. A coloração do material foi feita com azul de Astra e safranina (9:1), segundo Kraus et al [11] . Para diafanização de folhas minadas, utilizou-se solução de peróxido de hidrogênio e ácido acético (1:1), seguindo metodologia descrita por Kraus e Arduim [12]. As folhas diafanizadas foram coradas com safranina $1 \%$ e montadas em lâminas histológicas permanentes, com uso de bálsamo do Canadá.

As imagens foram obtidas com o uso de Sistema de Digitalização de Imagem (IM50) acoplado ao microscópio Leica DMLB do Laboratório de Anatomia Vegetal da Universidade de São Paulo. 


\section{Resultados e discussão}

Commelina diffusa e Floscopa glabrata apresentam folhas simples, glabras e com venação paralelódroma (Fig. 4.1A-D). Os agentes minadores observados nas folhas das duas espécies analisadas são dípteros, pertencentes à duas famílias: Agromyzidae em C. diffusa e Chironomidae em F. glabrata. As minas são espaços gerados pela ação do minador no tecido vegetal e, segundo Needham et al. [16], quando as larvas se alimentam de tecido parenquimático formando extensos túneis em uma única direção, as minas são chamadas de lineares e, quando a larva se alimenta em várias direções, a mina forma uma região delimitada conhecida por mancha ("blotch"). Além disso, Hering [7] descreve um caso intermediário em que o minador começa formando uma pequena mina linear e depois se expande formando uma mancha. Nas duas espécies de Commelinaceae estudadas, observou-se que a mina é do tipo linear (Fig. 4.1A-D), formando verdadeiras serpentinas. Trabalhos anteriores mostraram características semelhantes em outras espécies vegetais como Richterago riparia Roque (Asteraceae) [15] e Vismia guianensis (Aubl.) Choisy (Clusiaceae) [3].

Três cápsulas cefálicas de diferentes tamanhos foram observadas em uma mesma folha de F. glabrata, provavelmente resultado de mudas de um mesmo indivíduo. Duas dessas cápsulas são vistas na Figura 4.1D. A associação de dípteros, pertencentes à família Agromyzidae, como agentes minadores em Commelinaceae foi citada por Santos et al. [19] em Commelina diffusa Burn, sendo a principal hospedeira das larvas e pupas de Liriomyza commelinae.

Em corte transversal (Fig. 4.2A-D) as folhas não afetadas das duas espécies apresentam epiderme unisseriada, constituída por células com paredes não 
espessadas e isodiamétricas. Os cortes mostram ainda estômatos localizados ao nível das demais células epidérmicas, distribuídos em ambas as faces (folhas anfiestomáticas). O mesofilo dorsiventral, com idioblastos contendo ráfides ou cristais romboédricos. As unidades vasculares estão distribuídas na região mediana do mesofilo, com a endoderme (bainha parenquimática da unidade vascular) e o periciclo constituídos por células não lignificadas (Fig. 4.2B, D). Segundo Tomlinson [20], as folhas de Commelinaceae, freqüentemente, apresentam a bainha do feixe (aqui, neste trabalho endoderme) completa, podendo apresentar um espessamento de parede na porção inferior e superior ou apenas na inferior.

Quando um órgão vegetal é afetado por ação de algum agente minador ou galhador, a anatomia pode ou não variar. Melo-de-Pinna et al [15] descrevem que a diferença entre os dois tipos de endofitofagia (insetos minadores e insetos formadores de galhas) é que na mina há ausência de neoformação de tecidos. No entanto, Mani [14] embora mencione que em muitas minas o tecido vegetal permanece relativamente inalterado, ou seja, não há formação de novos tecidos, o autor descreve alguns casos de minas em que novos tecidos são formados próximo ao sistema vascular, como resultado de fatores mecânicos sem uma relação específica com a larva do agente minador. As minas das duas espécies de Commelinaceae, anatomicamente, não provocaram alterações estruturais, corroborando as observações feitas por Melo-de-Pinna et al [15] para Richterago riparia e Almeida-Cortez e Melo-de-Pinna [3] para Vismia guianensis.

As Fig. 4.3A-B mostram o local de entrada da larva do minador, na face adaxial da folha em ambas as espécies. Em corte transversal de folhas de $F$. glabrata (Fig. 4.3C e 4.3E) e C. diffusa (Fig. 4.3D e 4.3F) foi possível observar que o canal (mina) se forma pela consumição dos tecidos parenquimáticos do mesofilo. 
Durante a formação do canal a larva consome tanto o parênquima paliçádico como o lacunoso, mantendo a epiderme intacta, em ambas as faces (Fig. 4.3C-F), bem como os idioblastos contendo cristais e o sistema vascular. Este comportamento das larvas minadoras evitarem as unidades vasculares já foi descrito por Melo-de-Pinna et al [15]. Segundo as autoras, há uma possível relação com a presença de lignina nas células pericíclicas e xilemáticas e a fase de desenvolvimento do aparelho bucal da larva.

É interessante observar que nas duas espécies de Commelinaceae analisadas, as larvas minadoras não se alimentaram das unidades vasculares de médio porte (Fig. 4.3F), embora a endoderme (bainha externa) e o periciclo (bainha interna) sejam constituídos por células não lignificadas.

Quanto à fase de desenvolvimento das larvas minadoras em F. glabrata, observaram-se três exuvias cefálicas, indicando maior grau de desenvolvimento em relação à larva encontrada em $C$. diffusa. Contudo, não foi observada alteração no comportamento alimentar do inseto, a partir do material botânico examinado.

Uma característica comum em minas foliares é a epiderme permanecer intacta independente do agente minador ou grupo de plantas e é referida por diversos autores como uma proteção física das larvas minadoras. No entanto, Hawkins [6] menciona que a alta susceptibilidade de minadores foliares à parasitoides tem sido atribuída à pouca mobilidade da larva, associada à alta visibilidade da mina e escassa proteção física oferecida pela epiderme foliar.

Vários trabalhos têm relatado a ocorrência de minas causadas por Díptera, muitos dos quais mencionam espécies de Agromyzidae como hospedeiras de Hymenoptera [1, 2, 9, 21, 22]. No presente estudo, até a fase de desenvolvimento da 
larva minadora, não foi observado qualquer indício da presença de Hymenoptera endoparasita.

Salvo e Valladares [18] fazeram uma ampla discussão sobre a influência da forma da mina na vulnerabilidade à parasitoides e mencionam que os hospedeiros (larvas minadoras) em minas de manchas apresentam uma menor taxa de parasitismo quando comparados aos de minas lineares. Com base nesta relação, é possível que uma observação mais detalhada que inclua diferentes fases do desenvolvimento das larvas minadoras em $C$. diffusa e $F$. glabrata possa fornecer novos dados de endoparasitose em espécies de Díptera. 


\section{Referências}

[1] ABE, Y. 2006. Exploitation of the serpentine leafminer Liriomyza trifolii and tomato leafminer L. bryoniae (Diptera: Agromyzidae) by the parasitoid Gronotoma micromorpha (Hymenoptera: Eucoilidae). European Journal of Entomology, v.103, p.55-59.

[2] ABE, Y.; TAKEUCHI, T.; TOKUMARU, S.; KAMATA, J. 2005. Comparison of the suitability of three pest leafminers (Diptera: Agromyzidae) as hosts for the parasitoid Dacnusa sibirica (Hymenoptera: Braconidae). European Journal of Entomology, v.102, p.805-807.

[3] ALMEIDA-CORTEZ, J. S.; MELO-DE-PINNA, G. F. A. 2006. Morphology and anatomy of a leaf mine in Vismia guianensis (Aubl.) Choisy (Clusiaceae) in a fragment of Brazilian Atlantic forest. Brazilian Journal of Biology, v.66, p.759-763.

[4] BICKEL, D. J., 1982. Diptera. In: PARKER, S. P. Synopsis and classification of living organisms. New York: McGraw-Hill.

[5] BROWN, W. L. J., 1982. Hymenoptera. In: PARKER, S. P. Synopsis and classification of living organisms. New York: McGraw-Hill.

[6] HAWKINS, B. A., 1994. Pattern and Process in Host-Parasitoid Interactions. Cambridge University Press.p.

[7] HERING, E. M., 1951. Biology of the leaf miners. W. Junk, S-Gravenhage. 420 p.

[8] HESPENHEIDE, H. A. 1991. Bionomics of Leaf-Mining Insects. Annual Review of Entomology, v.36, n.1, p.535-560.

[9] JERVIS, M. A.; KIDD, N. A. C. 1986. Host-feeding strategies in hymenopteran parasitoids. Biological Reviews, v.61, p.395-434.

[10] JOHANSEN, D. A., 1940. Plant microtechnique. New York: McGraw-Hill.p.

[11] KRAUS, J. E.; DE SOUSA, H. C.; REZENDE, M. H.; CASTRO, N. M.; VECCHI, C.; LUQUE, R. 1998. Astra blue and basic fuchsin double staining of plant materials. Biotechnic \& histochemistry, v.73, n.5, p.235-43. 
[12] KRAUSS, J. E.; ARDUIN, M., 1997 Manual Básico de Métodos em Anatomia Vegetal. Rio de Janeiro: EDUR (Ed. Universidade Rural). 198 p.

[13] LABANDEIRA, C. C. 1998. Early history of arthropod and vascular plant assciations. Annual Review of Earth and Planetary Sciences, v.26, n.1, p.329377.

[14] MANI, M. S., 1964. Ecology of plant galls. Dr. W. Junk Publishers, The Hague. $434 \mathrm{p}$.

[15] MELO DE PINNA, G. F. A.; KRAUS, J. E.; MENEZES, N. L. D. 2002. Morphology and anatomy of leaf mine in Richterago riparia Roque (Asteraceae) in the campos rupestres of Serra do Cipó, Brazil. Brazilian Journal of Biology, v.62, p.179-185.

[16] NEEDHAM, J. G.; FROST, S. W.; TOTHILL, D. L.-M. I., 1928. Leaf-mining insects. Baltimore: The Williams \& Wilkens, Co. 351 p.

[17] RUZIN, S. E., 1999. Plant microtechnique and microscopy. Blackwell Synergy.p.

[18] SALVO, A.; VALLADARES, G. R. 2004. Looks are important: parasitic assemblages of agromyzid leafminers (Diptera) in relation to mine shape and contrast. Journal of Animal Ecology, v.73, p.494-505.

[19] SANTOS, J. P. D.; DAL SOGLIO, F. K.; REDAELLI, L. R. 2006. Plantas hospedeiras de dípteros minadores em pomar de citros em Montenegro, RS.

ARQUIVOS DO INSTITUTO BIOLOGICO (SÃO PAULO), v.73, n.2, p.235-241.

[20] TOMLINSON, P. B., 1969. III - Commelinales-Zingiberales. In Anatomy of the Monocotyledons (C.R. Metcalfe, ed.). Oxford, : Clarendon Press 446 p.

[21] TRAN, D. H.; UENO, T.; TAKAGI, M. 2007. Comparison of the suitability of Liriomyza chinesis and L. trifolii (Diptera: Agromyzidae) as hosts for Neochrysocharis okazakii (Hymenoptera: Eulophidae). . Biological Control, v.41 p.354-360.

[22] XU, P.; WAN, Z. W.; CHEN, X. X.; LIU, S.; FENG, M. G. 2007. . Immature morphology and development of Opius caricivorae (Hymenoptera: Braconidae), na endoparasitoid of the leafminer Liriomyza sativae (Diptera: Agromyzidae). Annals of the Entomological Society of América, v.100, n.3, p.425-432. 


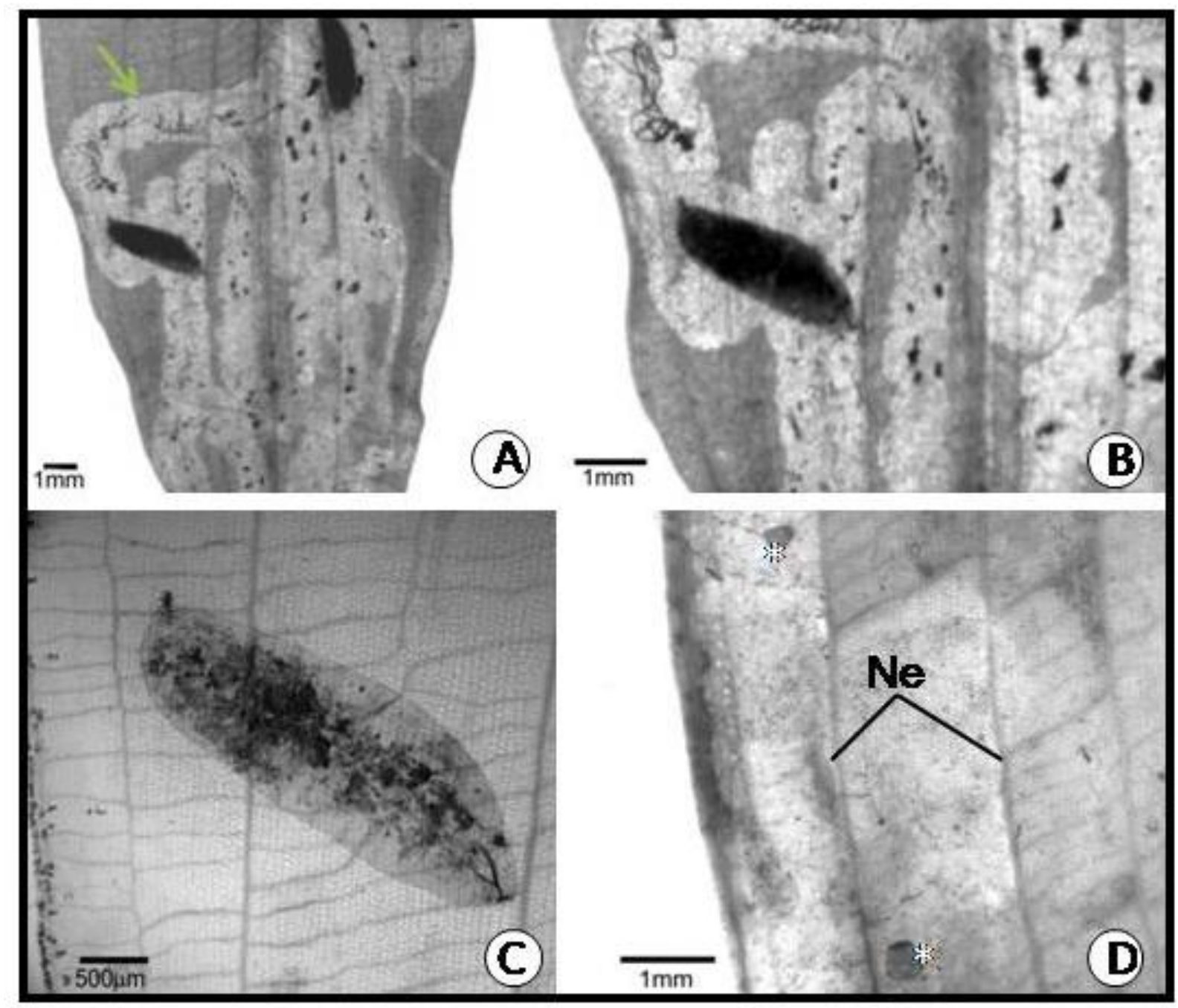

Fig. 4.1A-D - Vista frontal da folha minada de Commelina diffusa e Floscopa glabrata. (Commelinaceae) a partir de material diafanizado. Fig. 4.1A-B: larva de Agromyzidae em folha de Commelina diffusa, nota-se ainda, o caminho linear (seta) feito pelo minador. Fig. 4.1C: detalhe da larva do minador (Agromyzidae) visto por transparência. Fig. 4.1D: folha minada por (Chironomidae) de Floscopa glabrata; observe as exúvias cefálicas (asterisco) no mesofilo. $\mathrm{Ne}$ - Nervura paralela. 


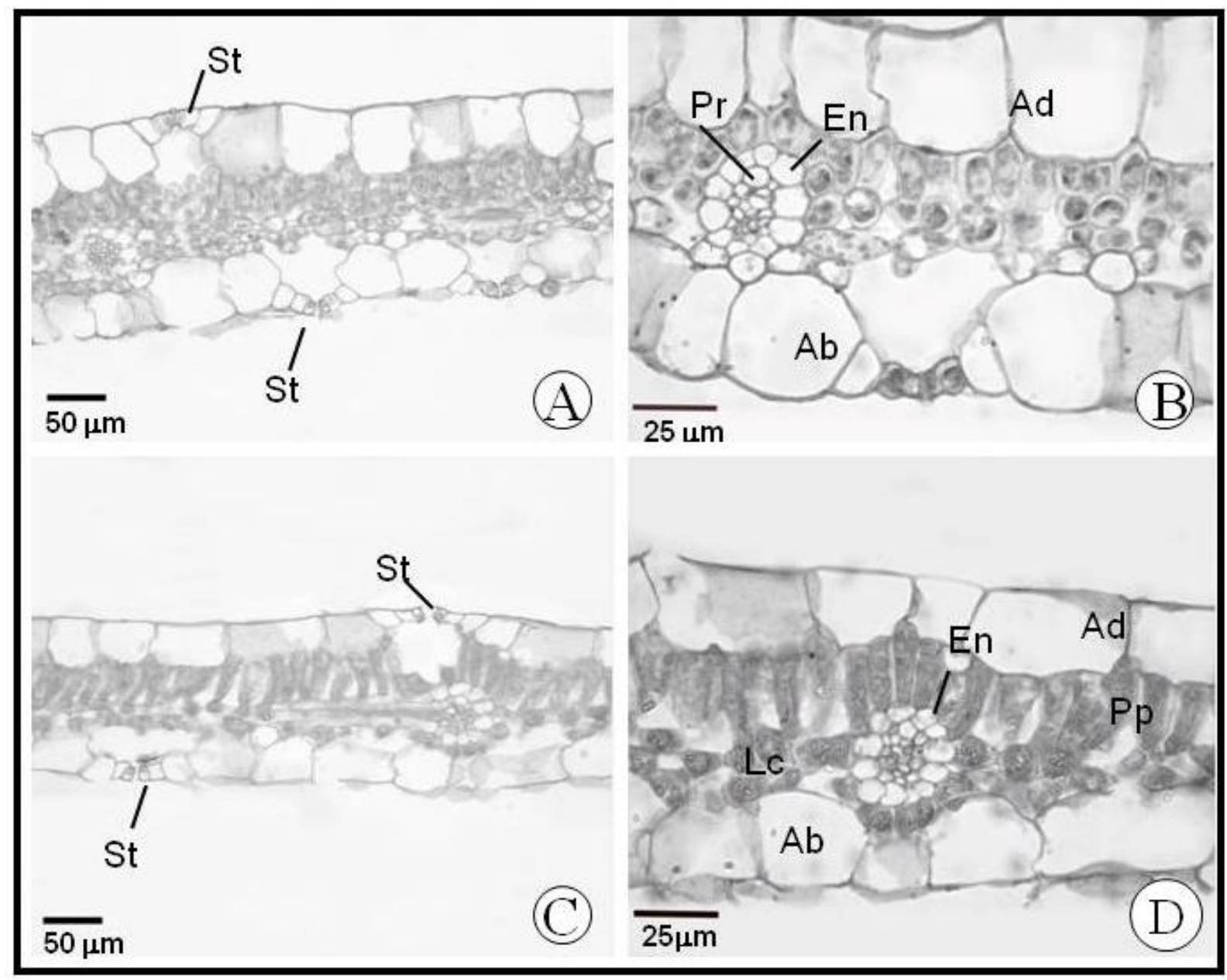

Fig. 4.2A-D - Seções transversais de folhas não minadas de Floscopa glabrata (Fig. 4.2A-B) e Commelina diffusa (Fig. 4.2C-D). Ab- Face abaxial da epiderme; Ad- Face adaxial da epiderme; EnEndoderme; Lc- Parênquima lacunoso; Pp- sdxParênquima paliçádico; St- Estômatos. 


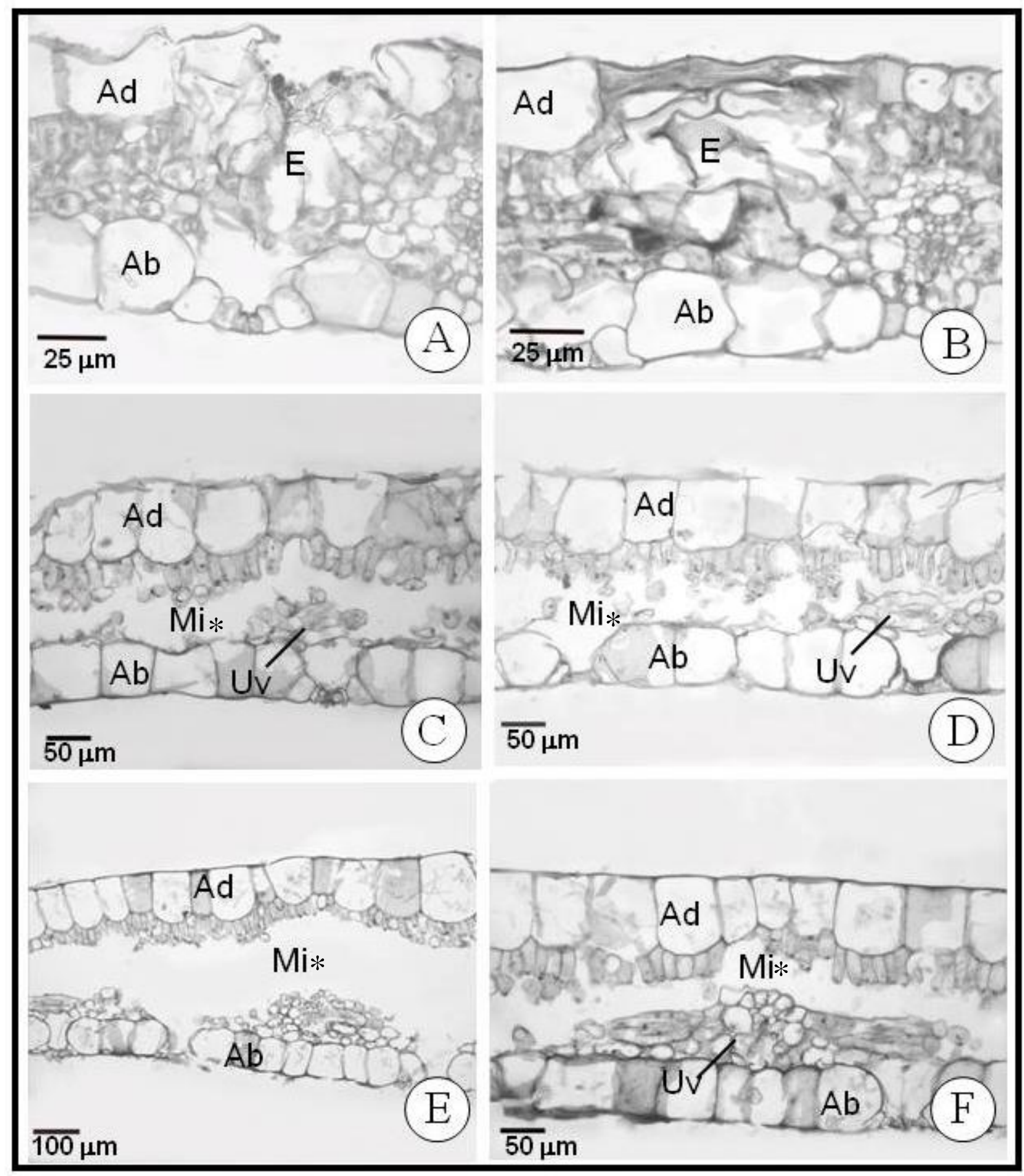

Fig. 4.3A-F. Seções transversais de folhas minadas de Floscopa glabrata (coluna à esquerda) e Commelina diffusa (coluna à direita). Fig. 4.3A-B: local de entrada (E) da larva minadora. Fig. 4.3C-D: mina $\left(\mathrm{Mi}^{\star}\right)$ formada pelo consumo dos tecidos parenquimáticos. Nota-se unidades vasculares (Uv) não consumidas pelo minador (Fig. 4.3C-D e F). 
CONSIDERAÇõES FINAIS 


\section{CONSIDERAÇÕES FINAIS}

Tendo em vista que o objetivo deste trabalho era demonstrar que 0 espessamento primário em monocotiledôneas resulta da atividade do periciclo associado à endoderme com atividade meristemática e que estes tecidos estão presentes nos diferentes órgãos vegetativos, pode-se inferir que:

A endoderme, na raiz é responsável pela formação do córtex interno (ou todo córtex), cujas células são denominadas de derivadas da endoderme meristemática (DEM); o periciclo origina raízes laterais

No caule, de Commelinaceae a atividade meristemática da endoderme e do periciclo é limitada a região nodal; no entanto, esta atividade meristemática é muito pequena, não promovendo o espessamento do órgão, como já observado em outras Monocotiledôneas que apresentam cormos, rizomas e bulbos. Apenas na região do nó verificaram-se divisões a partir de iniciais endodérmicas. Outra característica muito importante, que ocorre nessa região, é a formação dos complexos vasculares no centro do cilindro central da região nodal. Este estudo indica que os complexos são responsáveis pelo direcionamento dos traços foliares para a bainha da folha, porém há necessidade de uma análise mais aprofundada. O periciclo atua formando os feixes periféricos (na região do nó e entrenó) e os plexos radiculares na região do nó.

$\mathrm{Na}$ folha concluiu-se que os feixes são, na verdade, unidades vasculares, constuídos de xilema e floema primários, periciclo, envolvidos pela endoderme.

Assim, corroboraram-se com as pesquisas de Menezes e seus colaboradores que afirmam que todos os tecidos primários que estão na raiz, estão também no 
caule e na folha e também, confirmando idéia de continuidade entre os tecidos da raiz do caule e da folha. 